University of Rhode Island

DigitalCommons@URI

Open Access Master's Theses

1986

\title{
A PLANNER'S GUIDE TO LOCAL WILDLIFE CONSERVATION PLANNING AND IMPLEMENTATION
}

Stella Whisler Todd

University of Rhode Island

Follow this and additional works at: https://digitalcommons.uri.edu/theses

\section{Recommended Citation}

Todd, Stella Whisler, "A PLANNER'S GUIDE TO LOCAL WILDLIFE CONSERVATION PLANNING AND IMPLEMENTATION" (1986). Open Access Master's Theses. Paper 524.

https://digitalcommons.uri.edu/theses/524

This Thesis is brought to you for free and open access by DigitalCommons@URI. It has been accepted for inclusion in Open Access Master's Theses by an authorized administrator of DigitalCommons@URI. For more information, please contact digitalcommons-group@uri.edu. 
A PLANNER'S GUIDE TO LOCAL WILDLIFE

CONSERVATION PLANNING AND IMPLEMENTATION

BY

STELLA WHISLER TODD

\begin{abstract}
A THESIS PROJECT SUBMITTED IN PARTIAL FULLFILLMENT
OF THE REQUIREMENTS FOR THE DEGREE OF MASTER OF COMMUNITY PLANNING

AND
\end{abstract}

AREA DEVELOPMENT
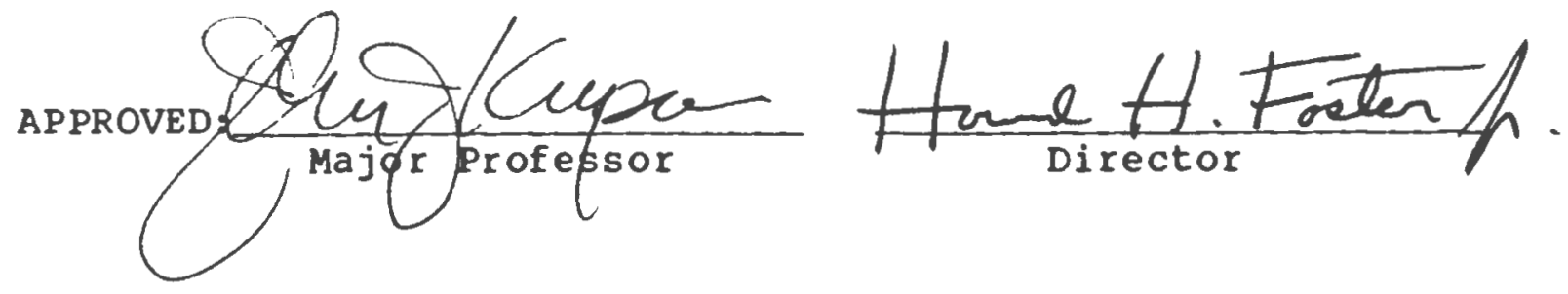

UNIVERSITY OF RHODE ISLAND

1986 
This thesis project is open for inspection, and can be used with due regard for the right of the author. The author herby grants permission to quote or paraphrase such minor parts as may be neccesary in any non-copywrited publication, providing that credits are given, showing the author's name and this project title.

This permission does not authorize reproduction of the entire report, or excerpting of major portions, permission for which must be granted in writing by the author. 


\section{Table of contents}

Dedication...................................

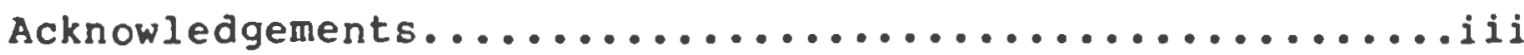

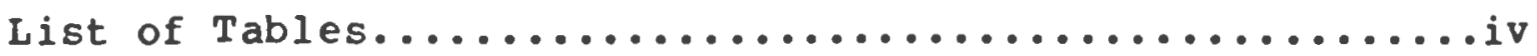

List of Figures...............................

Chapter One: $\quad$ Introduction......................

Chapter Two: Why Local Wildlife Planning...........4

Chapter Three: Developing The Wildife Plan.......... 31

Chapter Four: Implementation Strategies........... 78

Endnotes..................................

Appendix A: $\quad$ Sources of Information and Assistance....93

Appendix B: $\quad$ Regional Listings of Selected Plants Ranked According to Wildlife Value......106

Appendix C: $\quad$ zoning and Subdivision Ordinances...... 112

Bibliography................................ 149 
Dedication

To my father,

who never tired of learning and laughing. 
Acknowledgements

I wish to thank Dr. John J. Rupa, for convincing me that wildife biology and community planning are compatible, and for his continued support throughout the program.

I also wish to thank Dr. Peter August, for his

insightful review of this manuscript.

Finally, I would like to thank my parents, Francis and Laurence Whisler, and my husband Fred Todd for their encouragement. 


\section{List of Tables}

Table 1: The Retention of Genetic Variance in Small populations of Constant

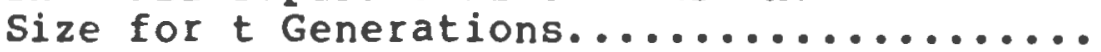

Table 2: Ten Intrinsic Wildlife Evaluations.......

Table 3: Nine Wildlife Planning Evaluations.......

Table 4: Five Economic Development Evaluations.....

Table 5: Relationship Between Animal Body

Size, Home Range, and Required

Corridor Widths. 


\section{List of Figures}

Figure 1:

Figure 2:

Figure 3 :

Figure 4:

Figure 5:

Figure 6:

Figure 7:

Figure 8:

Figure 9:

Figure 10:

Figure 11:

Figure 12:
The Relationship Between Bird

Species Number and Land Area..........

The Relationship Between the

Number of Land Mammals and

Island Area.

The Relationship Between Babitat

Diversity and species Diversity........

Classification of Streams as Primary, Secondary, or Tertiary, Based on Relative Location in a Watershed........

The Relationship Between Watershed

Divides and River Locations............

Determination of Habitat Units.........

Association of Different-sized

Carnivorous Mammal Species with

stream order......................

Identification of Unique and

Ir replaceable Habitats..............

Babitat Diversity as Illustrated

by Edges.

Compilation of Valuable Habitats.......

Habitat Units as Determined By

Movement Barriers and Watershed

Divides.........................

Preserves and Corridor Systems,

Overlayed on Habitat Units............ 


\section{A PLANNER'S GUIDE TO LOCAL WILDLIFE CONSERVATION PLANNING AND IMPLEMENTATION STRATEGIES}

By Stella Whisler Todd

CHAPTER ONE - INTRODUCTION

This report is written to community planners with the hope that they can engage in wildlife resource conservation planning without relying totally on outside expertise. Planners seldom have any training in wildlife biology or management. They may be reluctant to develop a wildlife conservation plan for their community, perceiving this task as being beyond their professional training and experience. Yet wildlife conservation can and must be an essential element of a community's comprehensive planning process. wildlife conservation principles can be understood and used by planners if clearly articulated. General guidelines for wildlife planning have been previously presented in planning literature. But specifics on how to go about such planning have been overlooked.

Goal

The goals of this report are to: 1) establish the importance of wildlife conservation planning by local communities, and present important ecological concepts to nonscientists, 2) develop a detailed wildlife planning methodology, which planners can practice in their communities, and 3) explore the legal basis for wildlife conservation zoning, 
and provide useful examples of local zoning ordinances. Communities should seek to maintain a diversity of wildlife species, within their geographical boundaries. Wildlife is valuable to the public for a variety of reasons. Animal species provide recreation, education, monetary gain, aesthetics, and a psychological sense of well being to local citizens. From an ecological viewpoint, the presence of particular animal species indicate the degree of ecosystem integrity. Loss of local species can eventually lead to permanent loss of genetic resources, which are needed by industry and agriculture alike. From a community health perspective, wildlife exhibit the adverse effects of chemical pollutants before human populations, and thus serve as environmental monitors. Wildlife conservation promotes both community welfare, and health.

A comprehensive community-wide wildlife planning methodology should include: 1) determination of community goals and commitment to wildlife resources, 2) alignment with other non-profit and governmental agencies with similar goals and objectives, 3 ) identification of valuable wildlife habitats, 4) determination of units habitat analysis, 5) compilation and mapping of valuable habitats, 6) prioritization of habitat values, 7) development of a corridor system plan, 8) establishment of wildlife conservation as an essential element of the community's Comprehensive Plan, and 9) development of relevant zoning ordinaces which support the wildlife plan. 
Scope

The scope of willidfe planning addressed in this report is on the town-wide or community-wide level. Such a comprehennsive overview is applicable to inclusion in a town's Master or Comprehensive Plan. This should be the first step in a community's efforts to manage its' wildife resources. While valuable knowlege of site specific landscaping practices which enhance wildlife habitat abounds, it is not a suitable substitute for large scale wildlife planning. Only with a comprehensive understanding of local natural resources can planners translate community policy into site specific applications. The Wildlife habitat evaluation and preservation priorities should be considered as a physical element of the Comprehensive Plan. Once habitat is identified, zoning and other techniques can be employed as the town's conservation strategy. Interagency cooperation is also imperative for successful large-scale planning ventures. 
CHAPTER TWO - WHY LOCAL WILDLIFE PLANNING?

Who is the client?

As with any planning venture, one of the first questions a planner faces is, who is the plan's client? often identification of clients for natural resource issue resolution is difficult in planning. Wildlife plans have no clearcut human clients, for in essence, the wildlife itself is the client. But, wildife pays no taxes, does not vote, and cannot claim the rights to representation as a bona fide community member. Yet the recognition that wildife resources are an integral part of the ecological community, which encompasses the human community, is imperative to effective wildife conservation.

While wildlife may justifiably deserve rights in human society, plans based on wildlife rights alone cannot suffice to convince citizens and the electorate alike. Rather, the value of wildife to people is much more convincing. The clients then are the people in a community who personally value wildife.

\section{Wildlife Values}

People value wildife for many reasons, be they for intellectual, ethical, cultural, economic or instinctive values. Eleven reasons why people value wildife have 2 been described . The first six are intellectual values 
based on the knowledge of how ecosystems operate, the quest for more knowledge, and the desire for continued ecosytem preservation. The next five are psychological, cultural, ethical and economic. They are as follows:

1. as a contributory component of ecological stability

2. as a monitor of environmental pollution.

3. for the maintenance of genetic variability.

4. for the provision of a source of renewable biological resources.

5. for the needs of scientific research into the environment.

6. to provide future generations with a wide choice of biological capital.

7. as a recreation resource.

8. as a component of the aesthetic quality of the landscape.

9. for moral and ethical reasons.

10. as a source of environmental education.

11. for the economic value of its resource, scientific and recreational components.

\section{Intellectual values}

The intellectual values associated with wildife conservation can be rationalized into wildlife planning schemes. These values should be considered in conjunction with aesthetic, ethical, cultural, and economic values. Intellectual values may be less personalized than aesthetic, ethi- 
cal, cultural or economic values, because they are based upon acquired knowledge about wildlife conservation and ecology.

Community leaders, conservation commissioners and planners may possess intellectual values not shared by an uninformed public. Therefore, it is the responsibility of ecologically informed individuals to communicate with other members of the community, to gain support for rational scientific approaches to wildlife planning. Planning should not only be directed at enhancing the "public good" but it should share with the public a common definition of this "public good".

One such value is the importance of wildife as a monitor of environmental pollution. Some citizens may hold this value because they understand how ecosystems operate. Those who don't, will not hold this value. Therefore, decisions made based upon ecological monitoring functions cannot gain support from the citizenry unless they understand it and embrace the concept.

Why is wildlife important for environmental monitoring? Because the effects of environmental disturbances will often be detectable in wildife populations before human populations exhibit effects. Wildlife, like people, need food, shelter, water, air, and space to survive. Unlike people, they are not buffered from their natural environment by artificial devices and environment. They receive the direct 
effects of pollution. Also, most wildlife species have much shorter life spars tha humans. So, effects occuring over many generations will te evident sooner in many animal species than in humans. For instance, fish die offs can indicate water pollution problems far in advance of human disease epidemics.

Another intellectual value is the importance of wild life as a renewable natural resource. This is also an economic value. Renewable means that wildlife populations can be sustained indefinitely in a stable environment, so present and future generations can fully enjoy and utilize wildlife. This value is important to any parent who values wildlife and wishes his or her children to do the same.

Scientists value wildlife as an endless source of investigation material. The intricacies of $l$ ife will never be fully understood, and the true value of scientific discoveries may not become apparent for eons of time. Scientists value their own work, but society may not appreciate it immediately. 'Many of the great advances in science and medicine came about as afterthoughts or experimental errors. It would be extremely shortsighted to think that all wildlife research should be directly applicable to solving immediate problems. It would also be shortsighted to believe that the full potential of an animal species as sources of medicine, food, and other necessary products has been realized.

Because so much is unknown about animals, the ability to provide future generations with a wide choice of biological 
capital is extremely valuable. Again, many informed individuals have already personalized this value. Those who depend on wildife economically realize the importance of this value, as do scientists.

The last intellectually based wildife value is perhaps the most important ecologically. It will determine the dynamics of ecosystem operations and may ultimately determine human survival. This value is the need for sustaining genetic variability and species diversity. A species is an interbreeding group of animals which can produce young who can themselves become fertile.

Genetic variation means that genes (DNA molecules that determine all traits and function within an organism) vary considerably among individuals of the same population. A population is an interbreeding group of the same species, occupying the same location. Genes are always present in double doses, called alleles, which may be dominant or recessive. Harmful alleles are often recessive. Two recessive alleles must be present for trait to appear, while only one dominant allele need be present for a trait to appear.

As population size decrease, less variation exists among all the alleles in a population (Table 1$)^{3}$. Hence, the likelihood that two recessive alleles will appear within any individual increases. Small populations will exhibit more undesirable traits than large populations. Members of these populations will be less successful in their environment, and 
TABLE 1

The Retention of Genetic Variance in Small Populations of Constant size for $t$ Generations

Percentage Genetic Variance Remaining after

$1,5,10$, and 100 Generations

Population

\begin{tabular}{ccccc} 
Size (N) & 1 & 2 & 10 & 100 \\
\hline 2 & 75 & 24 & 6 & 1 \\
6 & 91.7 & 65 & 42 & 1 \\
10 & 95 & 77 & 60 & 1 \\
20 & 97.5 & 88 & 78 & 8 \\
50 & 99 & 95 & 90 & 36 \\
100 & 99.5 & 97.5 & 95 & 60 \\
\hline
\end{tabular}

Source: Frankel, O.H., and M.E. Soule, Conservation and Evelutions. Cambridge University Press, Cambridge, 1981, p. 36 . 
will produce less young. Thus, ar entire population will become weaker and smaller through time. Extinction may occur at the point in time when this deteriorating process becomes irreversible.

Genetic variation and thus genetic stability will decrease from one generation to the next in small populations (Table 1). Even in populations of 100 individuals, only 608 of the original genetic variation exists after 100 generations. A generation is the young produced from the mating of two parents. Subsequent generations constitute the young produced from the young of the first mating and so on. In populations of two individuals, genetic variation is reduced to only 68 of the original variation (Table 1). For no loss in genetic variation through subsequent generations, population sizes of about 500 individuals are necessary. But sudden environmental changes such as drought or floods can increase this necessary size requirement. For genetic stability to be maintained, land quantity must be sufficiently large to support 500 or more individuals.

Babitat diversity is also land area dependent. Diversity indicates the number of different species a particular piece of land can support. Generally, the larger the area, the greater number of species which can be indefinitely supported. 
Evidence of this relationship has surfaced from island biogeography studies, which describe the spatial distribution of island species. For instance, some New Guinea islands lost up to 958 of their non-marine, lowland bird species (Figure 1) . The rate of collapse was inversely related to island size. The same relationship has been established for terrestrial mammals (Figure 2). This area effect is a firmly established geographic rule.

Babitat diversity will also effect species diversity. Diverse habitats will provide more varied food, shelter, and water sites and thus support more varied animals than homogeneous habitats.

Loss of species diversity will disrupt ecosystem stabi1ity. An ecosystem is a unit of physical and biological interaction in which energy flows and materials such as oxygen, water, carbon, nitrogen and phosphorus cycle. Animal species are an integral part of ecosystem cycles. Loss of species diversity will increase the vulnerability of remaining wild and domestic species of disease, droughts and other environmental catastrophies. Disruption of ecosystem dynamics will ultimately adversely effect human populations. Therefore, of the intellectual values placed on wildlife the maintenance of genetic variation and diversity is most critical to the survival of animals and humans alike. 


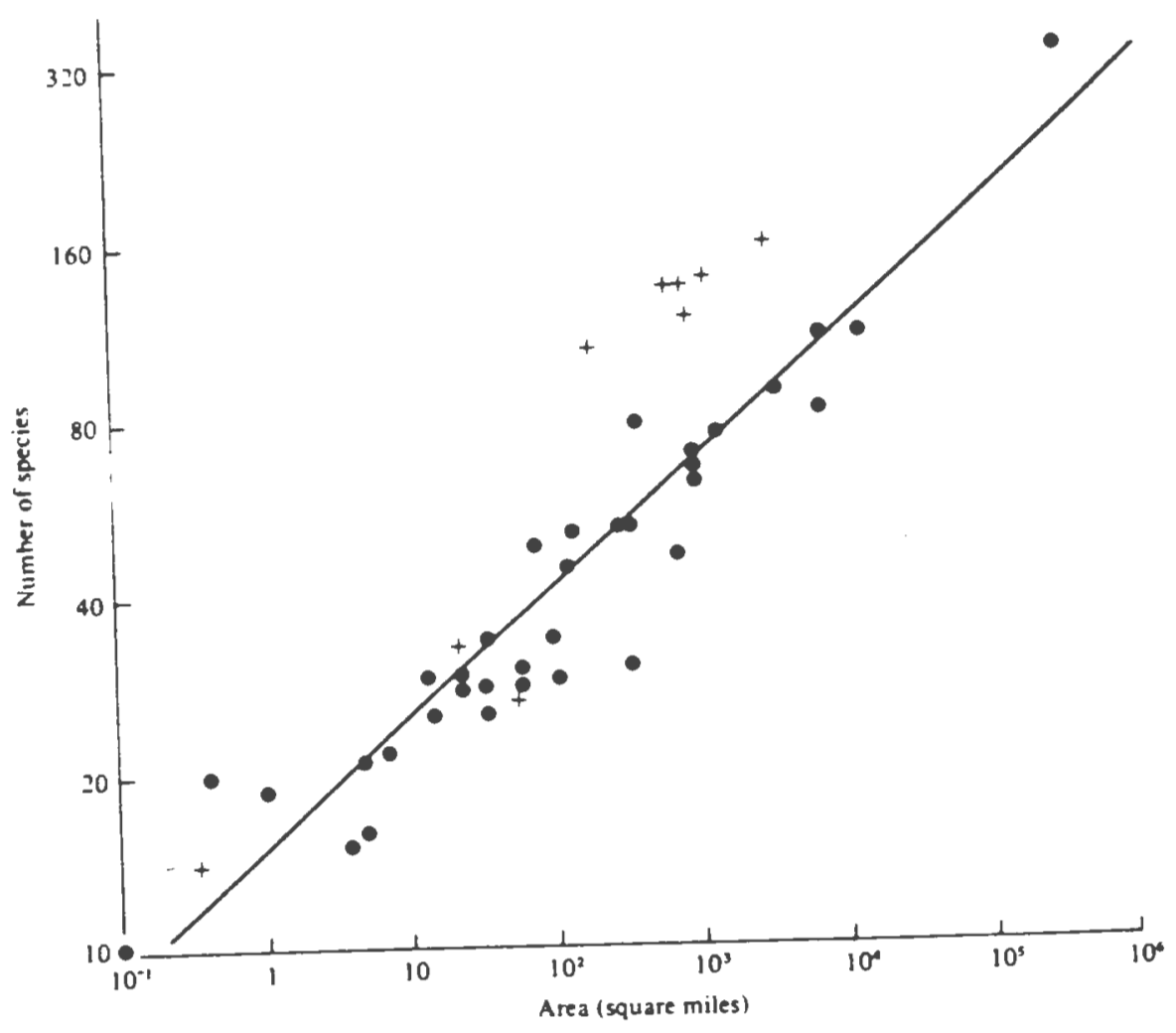

Figure 1: The relationship between bird species number and $l$ and area. The number of resident, nonmarine, lowland bird species on satellite islands of New Guinea, plotted as a function of island area on double logarithmic scales. The circular points are islands which have not had connection to New Guinea and whose avifaunas are presumed to be in equilibrium. The + points are islands connected by land-bridges at time of lower sea-level about 10,000 years ago.

Source: Frankel, O.H., and M.E. Soule, Conservation and Evolution, Cambridge University Press, Cambridge, 1981, p.164. 


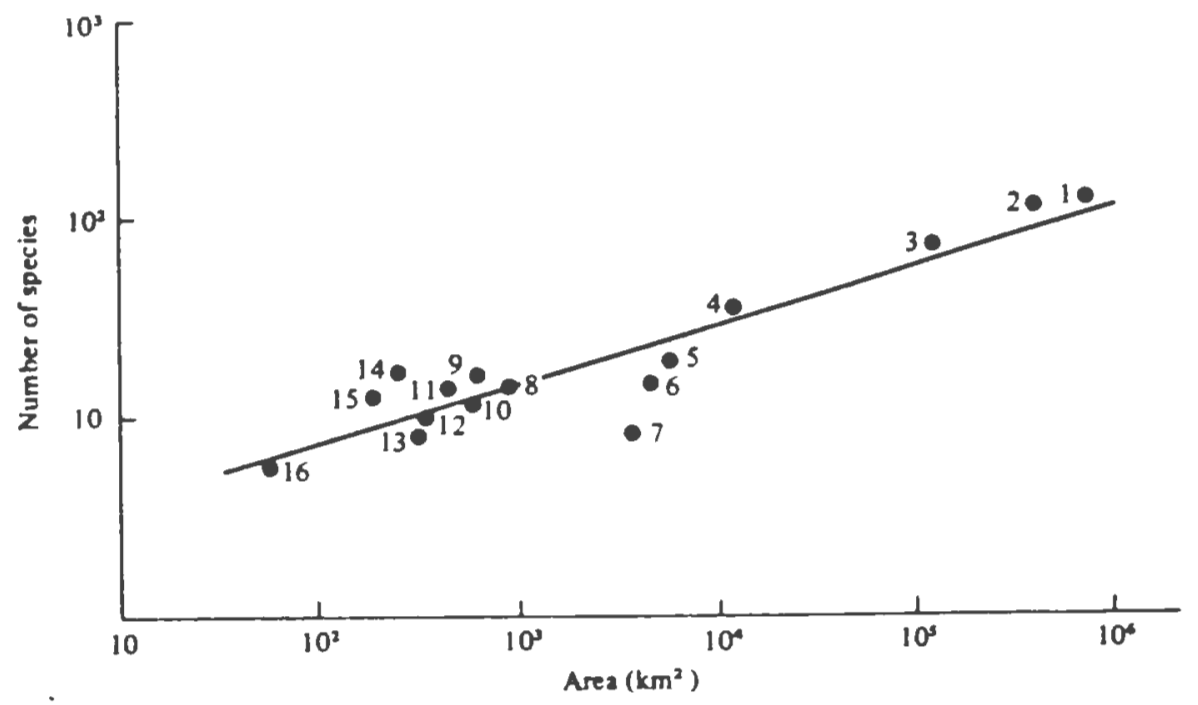

Figure 2: The relationship between the number of land mammals (excluding bats) and island area for the Sundra Island. (1) Borneo, (2) Sumatra, (3) Java, (4) Banka, (5) Bali, (6) Billiton, (7) Siberut, (8) S. Pagi, (9) Sipora, (10) Singapore, (11) Tanabala, (12) Tanamasa, (13) Pini, (14) Penang, (15) Tunangky, (16) Bangdaru.

Source: Frankel, O.H., and M.E. Soule, Conservation and Evolution, Cambridge University Press, Cambridge, 1981, p.101. 
Because wildife need clean water, food, adequate vegetation, cover, clean air and quiet, satisfaction of wildlife requirements improves human environmental quality. For instance, draining wetlands not only destroys valuable wildlife habitat but increases downstream pollution and flooding potentials. Noise restrictions close to wildlife preserve areas also increases the quality of life for residents. Vegetation retention during development not only provides good wildlife habitat, but also prevents soil erosion leading to water pollution and unstable building foundations. Vegetation conservation also provides residents with open space. So, wildife conservation often overlaps with other community goals.

\section{Non-intel lectual wildife values}

Recreation will continue to be a significant focus in people's lives. If wildlife resources are available they will be utilized extensively by the public. Be they sports people, photographers, or nature study hobbyists, wildlife captivates them all. As of 1965 , more than 108 of Americans took nature walks . A survey of Massachusetts forest landowners revealed personal recreation as the highest priority reason for owning a woodland . The value of wildlife recreation to people is often seriously underrated.

Probably the most important value of wildife to people is the fulfillment of a basic psychological need for 
natural beauty. The specific physiological reactions to natural beauty and diversity, to the shapes and colors of nature (especially to green), to the motions and sound of other animals, such as birds, we as yet do not comprehend. But it is evident that nature in our daily life should be thought of as part of the biological need. It cannot be neglected in the discussions of resource policy for man .

Aesthetic perceptions are so important that the acceptance of wildife plans could hinge on them. Planners must realize that land of high habitat value to wild ife may not be perceived as having high wildlife value to citizens. Perception is based on observation. Highly visible wildlife species and areas will be more highly valued than hidden, 11 sheltered areas. Landscape preservation values capable of being rationalized as public policy based on intellectual criteria must be coalesed with landscape preservation values associated with actual personal perception to gain public 12 support .

Preservation as a matter of ethics is fundamentally a religious arguement. No scientific proof for the right to exist is possible ${ }^{13}$. Most religions link man with nature in some way, and promote reverence for $l$ ife and or stewardship over the earth.

wildlife education can function either to increase one's appreciation of nature or to teach conservation principles to insure nature will be sustained. Education is 
a cultural value. People are not only interested in wildlife because of their own values, but wish to perpetuate and instill those values in their children.

wildife produces monetary gain from the commercial sale of recreational and sports equipment, literature, films, and other products. Wildlife species are used in the production and testing of medicinal products. They are also sources of food. Ducks, geese, turtles, large and small game, mammals, fishes, crabs, lobsters, oysters, shrimp, clam and mussels are commercially and individually harvested. The economic value of wildife is multiplied by the fact that the resource is renewable.

A community's values represent the cumulative values of its' citizens. Each community will possess a unique hierarchy of wildife values based on its' people and natural resources. Therefore, individual community wildlife plans should uniquely reflect the sum of citizens' values.

\section{Wildlife Planning as a Local Planning Issue}

The importance of local governments to the fate of wildlife has long been overlooked. Habitat destruction from the drainage of swamplands and wetlands by farmers and real estate developers, destruction of land by strip miners and builders, channelization of streams, clear cutting road building, and stripping away forests by timber companies, are perhaps the greatest threat to wildife presently .

Agriculture and forestry are becoming less diversified. 
In short, a land ethic changes the role of Homo sapiens from conquerors, to members of the land-community. It implies respect for his fellow members and also respect for the community as well".

The conservation minded politician, Stewart L. Udall, wrote "Local governments still hold the key to planning. Many zoning boards are as important as the courts. Zoning regulation should not merely prevent the worst from happening, it should encourage positive action to provide esthetic opportunity for the present and future while preserving the history of the past" ${ }^{19}$.

Writers for the Nature Conservancy, a non-profit organization, state that " diversity is so important to ecological balance which includes the human component that it should be a central planning focus. It seems just short of miraculous that the preservation of diversity has not become a basic raison d'etre for local land use planning. Instead, the land use planning movement has concentrated upon matters of carrying capacity and development constraint. Most likely a great deal more could be accomplished by gearing the effort toward protecting what is valuable" . While the efforts of a single community may not significantly effect the survival of any particular wildlife species, the cumulative effect of many community conservation efforts will. Local communities should direct their preservation efforts towards protecting valuable wildlife habitats with their borders. 
While state and federal wildlife strategies are imperative to sustaining species diversity, local governments are often in a better position to protect many local wildife resources. Local governments are often advantaged because 1) they have closer contact with citizens who are personally familiar with a community's resources both perceptually and physically, 2) they can follow through with plans and policies, because of daily interaction with community members. State and federal personnel may be in too short supply to oversee plan implementation, 3) they have more at stake to lose, if wildlife resources are irreplaceably destroyed and 4) they have the ability to regulate development practices through zoning and subdivision regulations.

\section{Limitations of State and Federal Jurisdiction Concerning} Wildlife

While state and federal programs and policies directed towards protection of target species, or the preservation of diversity are imperative to the sustenance of many wildlife species, their jurisdiction and power is limited. Local government programs and policies will fill in the gaps of wildife resource protection. States can act directly to preserve wildife habitat but may be reluctant to override local zoning authority. The federal government can regulate national and international wildlife trade but not privately owned wildlife habitat. Federal focus on private lands is primarily through incentive programs. 


\section{Rederal laws, treaties and programs}

The following important Federal Laws, Treaties and Programs clarify the powers and limitations of the Federal government control over wildlife resources ${ }^{21}$.

Under the U.S. Constitution the federal government reserves the $r$ ight to international treaty making and the regulation of interstate commerce - International treaties primarily concern the taking, importing and transporting of animals, and cooperative research and conservation agreements. For instance, the Endangered Species Act of 1973 prohibits unauthorized taking, possession, sale, or transport of endangered species. It does not, however, prohibit irreparable habitat alteration by individual landowners.

Federal laws applying to Federally owned lands and federally funded projects are more stringent and specific. For instance, fish and wildife conservation at Federal reclamation projects authorize $\mathrm{fish}$ and wildlife conservation at water resources projects of the Bureau of Reclamation, in the Department of the Interior. The National Environmental Policy Act of 1969 requires that any Federal actions significantly affecting the quality of human environment require a detailed environmental impact statement. Other acts regulate activities within National wildlife refuges.

In addition to international treaties and federal control over federal land and projects, many acts have been established promoting federal and state combined ventures. 
These acts do primarily supply funds to mutual state federal projects. The Fish and Wildlife Improvement Act of 1978 authorizes the establishment for law enforcement training for state fish and wildife law enforcement personnel. The Land and Water Conservation Fund Act of 1969 provides matching grants to states for outdoor recreation projects. And the Endangered Species Act of 1973 authorizes establishment of co-operative agreements and grant-in-aid to those states which establish and maintain an active and adequate program for endangered and threatened wildife.

A very important recent federal policy is set forth in 23 the Fish and wildlife Conservation Act of 1980 . In section $2 a$ the Act acknowledges that "Fish and wildlife are of ecological, educational, aesthetic, cultural, recreational, economic, and scientific value to the nation." It recognizes that historical fish and wildife conservation programs that focus on more recreationally and commercially important species do not adequately meet the needs of non-game fish and wildlife. Each state is encouraged to develop, revise, and implement in consultation with appropriate federal, state, and local and regional agencies a plan for the conservation of fish and wildlife, particularly those species which are indigenous to the state. Inter-agency cooperation is recognized as being essential to effective programs.

Conservation is defined, in the Act, as methods and procedures which are necessary to ensure, to the maximum 
extent practicable, the well being and enhancement of fish and wildife and their habitats for the ecological, educational, aesthetic, cultural, recreational and scientific enrichment of the public. Methods and procedures include, but are not limited to, scientific resources management, such as research, census, law enforcement, habitat acquisition, maintenance, development, information, education, population manipulation, propagation, technical assistance to private landowners, live trapping and transplantation. Fish and wildlife means wild vertebrate animals such as mammals, birds, fish, reptiles, and amphibians.

\section{state laws}

Currently, states bear the major burden for wildlife management. This is because under the U.S. constitutional provisions, the states have primary legal responsibility for wildife protection and administration, both through their administration of well established and recognized doctrine of public ownership of wildlife, and through police power . But state doctrine relates primarily to the control of wildlife and to the manner in which hunters and fishermen utilize the resource, not to the habitat upon which wildife production depends. The landowner controls the habitat upon which 25 wildife production occurs.

Legislation such as the Fish and wildlife Conservation Act of 1980 indicates that the state's role in wildlife protection will be more habitat preservation oriented than in 
the past. Although zoning was not mentioned as a conservation method, it was not restricted. States car zone land directly. If zoning powers have been delegated to local municipalities, stais may find considerable local resistance to state zoning. Local governments may feel that states already have too much control of their own internal affairs.

Some states have applied zoning principles directly to wildlife conservation issues. The validity of such methods have been upheld in recent Supreme Court cases. The states of New Jersey and Florida have been directly involved with wildlife habitat protection through zoning. Two cases: Orlean Builders and Developers v. Byrne, and Sarasota County v. Barg will be discussed.

\section{State zoning cases}

In the case of Orleans Builders and Developers v. Byrne, a cedision of the Pinelands Planning Commission denying a developer's application for a major development was ap26 pealed - The Pinelands Planning Commission was established to develop a plan and review all proposals for the Pinelands National Reserve. The Reserve was created through a 1978 Congressional amendment to the National Parks and Recreation Act. New Jersey was given responsibility to develop a management plan to protect the Pinelands natural resources. Within this general category, wildife resources were specified. These included endangered, unique and unusual plants, 
and animals, and habitats of the Pine Barrens tree frog (an endangered species), and the pine snake (a threatened species) .

The developer in this case wished to create a larger development than wis permitted under the management plan and he charged inverse condemnation of his property. This charge was dismissed by the court, because the developer was not deprived of beneficial use of his entire remaining undeveloped property. The court found any restrictions on development were to prevent public danger or to protect against threats to public interest.

Another case in Florida, (Sarasota County v. Barg) involved a challenge to density and use restrictions placed on residences within the Manasota Rey Conservation District. The District was created by a Florida Act, which declared 29

the area a marine life sanctuary - Owners of property within the District brought actions for declaratory judgment to determine the constitutionality of the Act. The court found all legislative enactments to be valid. The use of police power to preserve natural resources was upheld. It stated that:

"when an area is uniquely scenic and has the rare natural quality of serving as a haven or refuge for marine, animal, and bird life, it may well be the subject of legislative protection under the state's police power."

Both of these cases indicated that the protection of unique and or endangered plants and animal species is in the public's interest. They upheld the validity of zoning ordi- 
nances in the interest of wildlife preservation at the state and local level. Although the Pineland National Reserve was established through a National Act, its' management was delegated to the state, which in turn could delegate it to local governments. In the case of Manasota Rey Conservation District, the state identified a high value natural resource area, and essentially created its' own overlay zone. Within this overlay zone, development restrictions were developed which specifically protected wildlife habitat. States do have legal authority then, to not only regulate animal harvest as they have traditionally done, but to regulate valuable wildlife habitat through zoning as well.

Other examples of states directly using zoning as a natural resource management tool are the Hawaiian Land Use Law of 1961, and the Maine Site Location Law of 1971 . The Hawaian law divided the state into conservation, agricultural, rural and urban districts. Local zoning regulations applied to urban districts. Agricultural and rural districts were regulated by the State Land Use Commission, and conservation districts were under the control of the Department of Land and Natural Resources. The state established its own "super zones" that superseded local land use authority. The Maine Site Location Law required state approval of certain types of new development in areas where local governments had adopted no land use regulations. 


\section{Lecal zoning cases}

No appellate or supreme court cases exist which challenge local zoning ordinances specifically protecting wildlife habitat, but this does not indicate a lack of local zoning in this regard. Although rare, some communities have included wild ife preservation within their community goals. One such community is Jackson Hole Wyoming.

Jackson Hole, Wyoming is a town of 11,000 people, within Teton County. The County is located in the northwest corner of Wyoming, adjacent to Teton National Park, and south of Yellowstone National Park. Jackson contains a National elk refuge which accommodates a wintering elk population almost as large as the human population. The region is known for its superb scenic beauty and big game animals. Consequently, tourism is the major industry in the immediate area. In view of these facts, it is not suprising that wildife is considered a valuable community resource.

The Town of Jackson Development Code contains specific wildife protection provisions, which apply to all identified wildlife reserves, riparian areas and critical winter habitats, including waterways and surrounding water bodies

31

Challenges to local preservation zoning regulations such as those in Jackson are eminent. Will courts uphold local zoning regulations, as they have state instigated regulations? Is concern with wildife habitat loss a valid local purpose? Does wildlife serve a public purpose only in commu- 
nities whose economic foundations are based on their wildlife resources? Or is ecological balance in itself a valid community purpose?

Although no local ordinances protecting wildlife habitat have been challenged, similar types of ordinances acted to preserve an adequate water supply and ecological balance of the area. The court found that just as historical character and aesthetic appeal of a community were legitimate concerns, so was the community's ecological balance as the result of urban development.

The court futher stated that:

"Respecting ecology as a new factor, it appears that the time has come--if, indeed, it has not already irretrievably passed--for the courts, as it were, to take "ecological notice" in zoning matters."

"(5). . the municipality has here presented sufficient evidence to warrant the rezoning of the petitioner's property, for it was prompted to do so by ecological considerations based not upon whim or fancy, but upon scientific findings. The definition of "public health, safety and welfare" surely must now be broadened to include and to provide for these belatedly recognized threats and hazards to the public weal. The Town's decision to forego what, undoubtedly, would be substantial addition tax revenue would appear to constitute a recognition that it as well as an owner must subordinate immediate to long-term interests."

From the preceding case and other cases, ecological 34

balance is considered a valid purpose . Municipalities have the authority to determine what kind of activities will adversely effect ecology, and they can enact legislation to minimize these effects. Ecology is the study of inter- 
relationships between organisms and their environment. Certainly wildife is an integral part of this discipline.

While courts have upheld ordinances preventing ecological harm in local communities, one Florida case indicates they may be antagonistic to ordinances enacted solely for community benefit. In Bob Grahm v. Estuary Properties, Inc., the court found that while preventing pollution was a valid exercise of police power, the retention of forest simply to create a public benefit by proving a source of recreational fishing for the public was a regulatory 35

taking . This contradicts the courts opinion in Moviematic Inc. $v$ Bd. of county comm'rs. who held that:

"With respect to the objective of preserving
ecological systems, zoning regulations which tend
to preserve the residential or historical character
of the neighborhood and to enhance the aesthetic
appeal of the community are considered valid
exercises of the public power as relating to the
general welfare of the community

How courts view these changes will depend on how they interpret the meaning of ecology. Until more specific terms are used in ordinances, it will remain difficult to predict how courts will react.

Local municipalities can justifiably enact zoning ordinances directed towards protecting rare and endangered animals and or preserving wildlife habitat. There is some ambiguity whether courts will uphold all habitat preservation ordinances as having a valid public purpose. Some interpret ecological preservation ordinances in the context 
of promoting general welfare, while others interpret such ordinances as promoting public safety. In some states, it may be necessary to not only show community benefit from a specific zoning ordinance, but to show that without the ordinance the community will be harmed. For this reason the importance of wildife for ecological balance, ecosystem functioning, public health, education, and economics should be stressed when drafting legislation along with recreation, aesthetics, and ethics, regardless of community wildlife values.

Municipalities interested in habitat preservation management, should consider the taking issue when drafting ordinances. Towns should provide for alternative administrative channels short of court battles, for aggrieved landowners, suffering unreasonable hardships, because of zoning regulations.

Finally, although most zoning ordinances involve regulation of residential, commercial and industrial activities, they could easily be adapted to include management of agricultural and forestry activities within a community. Wildlife should be considered simultaneously with more traditional community goals when comprehensive plans and zoning regulations are created.

When Is Wildifife Planning Necessary?

Wildife Planning is important to all communities regardless of their indigenous wildlife resources. This 
report focuses on communities with enough existing wildlife habitat to warrant habitat preservation. This includes all communities except those extensively urbanized. Urban governments will focus on the creation of wildlife habitat where none exists, through landscaping or park development. Rural or urbanizing communities will focus on the preservation of valuable existing wildlife habitat.

Communities possessing the following wildlife habitats should develop preservation plans.

1) Habitats of endangered, threatened or rare species.

2) Unique or irreplaceable habitats.

3) Habitats of high species diversity.

4) Habitats of species valued for recreational, aesthetic, educational, scientific, or economic reasons. The ideal community for wildlife planning is one that has abundant wildlife resources and low development pressures. This may seem ironic, because if development pressures are low wildlife will not be threatened. But sensitive and unique lands in slow growth towns can be zoned for preservation purposes with little opposition. Also, purchase of those lands is possible at low real estate prices. Early policies will set the stage for conservation minded development. Unfortunately, rural communities rarely percieve the need for natural resource planning. They don't have much incentive to undertake preservation projects when no immediate threats are present.

A community with abundant valuable natural resources and 
rapid existing or potential growth has the incentive for wildife planning. If it acts quickly and aggressively, it can protect valuable wildife resources without tremendous fiscal burdens. Once growth accelerates, land prices will rise quickly, and the option to purchase conservation lands will rapidly disappear. However, zoning and subdivision controls remain options, regardless of land prices.

Rapidly growing communities with few unique and naturally diverse areas remaining also need to plan for resource protection. These communities may in fact possess a larger proportion of threatened or endangered species simply because habitat is scarce. If so, efforts should be directed and coordinated with state and federal agencies immediately.

In summary: 1) Wildife conservation is an important element of a community's health, safety and general welfare, based on wildlife as an integral element of ecosystem functioning, of which human commities are subject. 2) Wildlife is valued by people for many reasons. 3) Wildife planning is a local responsibility, as well as a state, regional, and federal responsibility. 4) Wildlife planning is legally justifiable under the general powers of zoning. 5) The best time to begin planning is now. Extinction is forever, and once valuable wildife habitats are destroyed they cannot be reclaimed without very expensive and time consuming efforts. 
CHAPTER THREE - DEVELOPING THE HILDLIFE PLAN

How does a planner go about developing a community-wide wildife conservation plan? While this task may seem insurmountable, it can be successfully undertaken methodical1y. The ten important steps to wildlife planning are as

\section{follows:}

1) Determine community goals and commitment to wildife resources.

2) Align with other local, regional, state and federal non-profit and governmental agencies with similar goals and objectives.

3) Identify valuable wildlife Babitats.

4) Determine habitat units based on animal movement barriers and ecosystem functioning.

5) Compile and map valuable habitats.

6) Prioritize habitat unit values based on intrinsic wildife values, and wildlife planning values.

7) Determine habitat unit values based on economic development opportunities.

8) Develop corridor system plan based on maximizing total habitat unit values.

9) Establish the wildife plan as an essential element of the community's master plan.

10) Develop zoning regulations applicable to preservation of biologically sensitive areas within habitat units, and or enhancing habitat productivity. 
Community Goals And Comoitment To Wildilfe Resources

There are two ways to approach planning. One is for professional planners, elected officers, and administrators to decide what is best for the the community and convince them of it. The other is to determine what the community needs and wants, through use of surveys and personal inverviews, and then plan to satisfy those needs and wants. The best approach is a combination of both.

From a community viewpoint, the most rational goal of wildife conservation is the maintenance of ecological diversity and genetic variability. Because human communities are an integral part of natural ecosystems, their stability will have a significant effect on human health, safety, and welfare. Both ecological diversity and genetic variation promote ecosystem stability.

Ecological stability will always effect the health, safety, and welfare of a community. Planners must educate the public about the values of ecological diversity and stability, so that previously uninformed citizens can embrace and personalize these values. They must also learn what values toward wildife resources are held by citizens who compose the community. Both sets of values should be considered in the development of wildlife plans. 


\section{Allignment With other Agencies With Similar Goals}

\section{And objectives}

Wildlife conservation goals will best be realized through inter-agency cooperation. This ideal is not easy to achieve. Different agencies will have different goals, even within the wildife conservation field itself. All agency goals cannot be realized simultaneously.

One current wildife planning guide suggests for planners to consult with biologists in evaluating wildlife habi37 tats for larger-scale planning . Community goals should be clearly articulated prior to any consultation. Biologists from different agencies will analyze identical habitats differently depending on their own orientation. Once town goals are firmly established, i.e. our town is particularly interested in endangered species habitat or in species diversity, then biologists can help identify these habitats.

Lack of consensus about which habitats are valuable, should not discourage planners to seek help from biologists. Rather, it should accentuate the need to clearly establish local community goals toward wildlife preservation before professional biologists are consulted. Then communities are not dispatchers of other agencies' programs, but are equal participants in wildlife conservation efforts. It is important for communities to establish their own identity and orientation to their wildlife resources. Then, interaction with biologists from different agencies will help clarify or readjust community goals and programs, so that optimal cooperative inter-agency agreements can be reached. 


\section{Wildlife Habitat Identification}

The next step is to identify valuable wildife preserve habitats. This step is the most critical for successful conservation planning. Important wildlife areas have already been described as those 1) of endangered, threatened, or rare species, 2) unique or irreplacable habitats, 3) habitats of species valued for recreational, aesthetic, education, scientific, or economic reasons, 4) habitats of high species diversity. Valuable habitats can be identified through information derived from a variety of sources (Appendix A) .

\section{Endangered species}

Identification of endangered, threatened, or rare species habitat requires consultation with other agencies, such as the U.S. Fish and Wildife Service, state fish and game departments, and local naturalists (Appendix A). Local Audubon Societies may have knowledge of endangered species habitat occurrences. Public and University libraries contain many reference books which can help identify the location of endangered species habitats. The Liason conservation Directory for Endangered and Threatened Species is a very important source of contacts for local wildife planners. It lists federal and state endangered species ex- 
perts. For a copy, write to:

\author{
Editors \\ Liason Conservation Directory \\ office of Endangered Species \\ U.S. Fish and wildlife Service \\ Department of the Interior \\ Washington, D.C. 28240
}

Although identification of endangered, threatened or rare species habitat is relatively difficult, its' value to wildife planning is singularly important. Community actions can make the difference between survival and extinction of animal species. Although many of the largest endangered animals, with extensive habitat requirements, cannot be protected by community efforts alone, smaller species can be protected at the community level. Local, statewide, regional, and national efforts must be coordinated to insure the survival of many of our endangered animal species.

The danger of municipal neglect of endangered species habitat is evident in a survey of U.S. urban conservation leaders. Although they expressed interest in rare and endangered species, few leaders could identify resident animals in that category ${ }^{38}$. Therefore endangered wildifife played no role in aquisition of conservation land. Yet rare and endangered species preservation is one objective sure to find considerable citizen support. Emphasis on this objective could carry an entire wildlife plan through. 


\section{Unique and ir replaceable habitats}

Unique and irreplaceable habitats can be identified by consulting with biologists and naturalists. They can also be identified through the use of vegetation maps, U.S. Geological Survey maps(U.S.G.S.), aerial photographs, and infrared remote sensing images such as LANDSAT. Unlike endangered species habitats, planners can identify these areas by themselves, by obtaining maps and images from state, federal and local public and private agencies (Appendix A). Unique habitats are those found rarely within a community. They are valuable because they will support a unique variety of animal species. These species may or may not be endangered, threatened, or rare on a statewide or national level. There value may not be significant on an ecosytem level, if adjacent areas contain an abundance of these seemingly unique habitats. Still, their rarity within the community makes them valuable to local citizens.

Irreplaceable means that once the habitat is disturbed is cannot be recovered. This is true of any habitat that is paved over or built upon. So, essentially all habitats undergoing urbanization are irreplaceable. For planning purposes, irreplaceable means that to recreate a comparable habitat in another area would be extremely costly, time consuming, and of questionable success. An example of this would be trying to build wetlands in new areas to replace those destroyed in others. In contrast, an early succession 
field would be relatively simple to recreate in another area.

\section{Highly diverse habitats}

Species diversity is primarily a function of habitat size and habitat diversity (many vegetation types). The greatest number of wildife species will benefit from large preserves containing diverse habitats. However, some species may require extremely large areas of continguous and similar habitats . These will suffer from diverse habitat blocks. It is impossible to maximize diversity and at the same time maximize numbers of a particular species. Thus diversity must be considered in combination with the needs of target species, such as threatened or endangered species $^{40}$.

Where endangered or threatened species' habitats have been identified, within a particular habitat unit, habitat diversity may not be a desirable planning objective. In other units, diversity should be a goal. While diversity may not benefit any one particular species, it benefits the largest number of different species.

Diverse habitats can be identified by planners using vegetation and U.S.G.S maps and remote sensing (Appendix A). One species diversity index estimates diversity based on the length of edge relative to area. Edges are boundaries between two distinct habitat types. Often habitats overlap, forming a region called an ecotone. Edges and ecotones are 
rich in wildlife, both in number of species, and of individuals, because of the additive effect on the fauna when two plant communities or successional stages meet (Figure 3$)^{41}$. As edge quantity increases so does diversity, until habitat blocks become too small to support diverse animal species.

One study, on bird populations concluded that for vertebrate wildife, the optimal average habitat block size which maximized species diversity is from 74 to 99 acres $(3 \theta-40$ hetares). For average block sizes smaller than the optimum, the diversity decreased rapidly. For larger block sizes diversity decreased slowly then leveled of . From this single study, it is impossible to generalize as to the optimum quantity of edge and homogenous habitat blocks to support the maximum quantity of species in all regions, under all conditions, but it does provide some important insites for planners. First, it indicates that more of a good thing (edge) is not always better. Species diversity loss is relatively greater when edge quantity per unit area exceeds the optimum, than when edge quantity is less than optimum. When in doubt, planning schemes which maintain homogenous habitat are preferable to those which form smaller heterogenous habitats. 


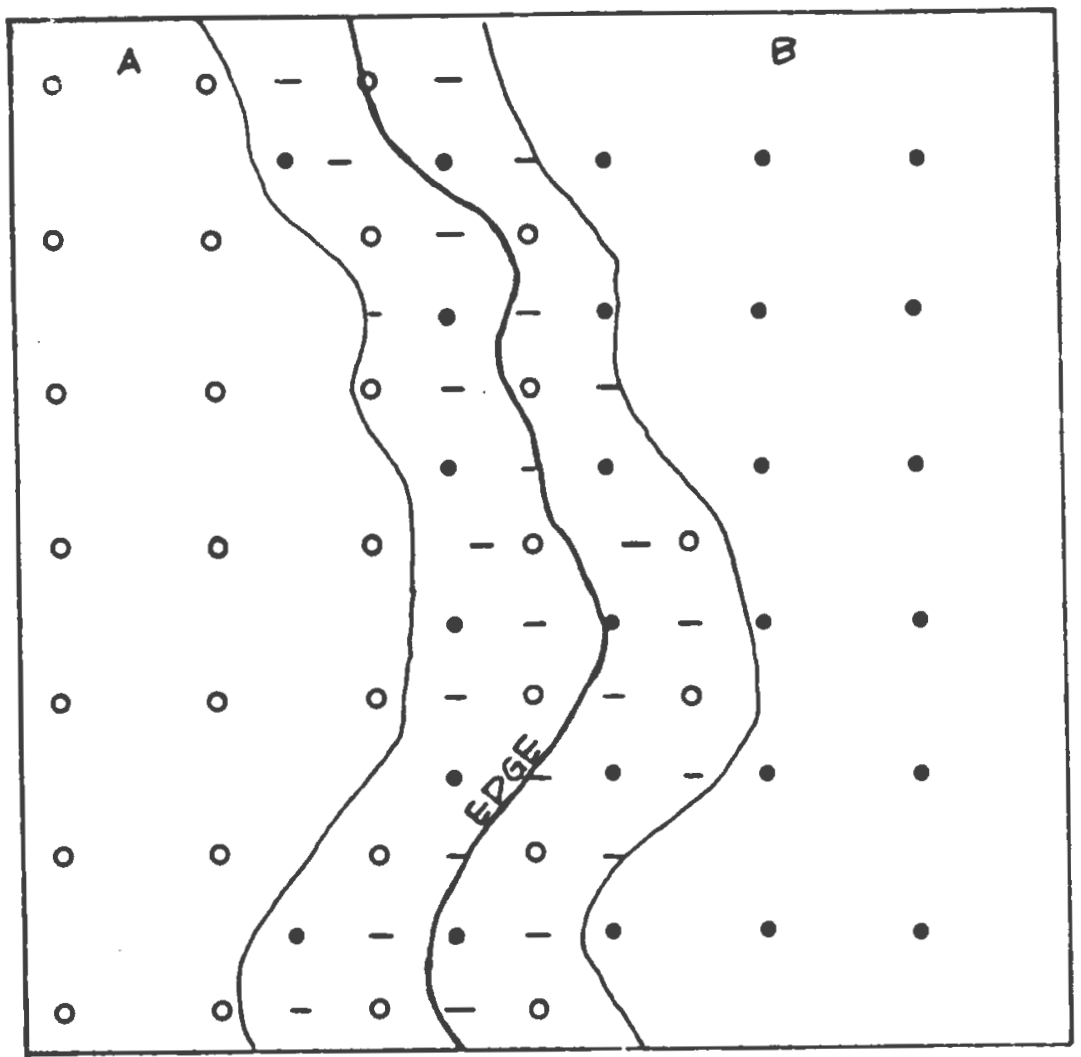

Figure 3: The relationship between habitat diversity and animal species diversity. Habitat $A$ species are designated by - and Habitat $B$ species are designated by 0 . Habitats meet at the edge. Some overlap of habitats and species occurs within the ecotone, designated by -. Ecotones are richer in species than either habitat $A$ or $B$ alone.

Source: J.W. Thomas, Wildlife Habitat in Managed Forests: The Blue Mountains of Oregon and Washington, U.S.D.A. Forest Service, Wildlife Management Institute, and U.S.D.I. Bureau of Land Management Agricultural Handbook No. 553, 1979, p.51. 


\section{Diversity index calculation}

The following is an example of one of the many indexes of diversity which planners can utilize ${ }^{43}$.

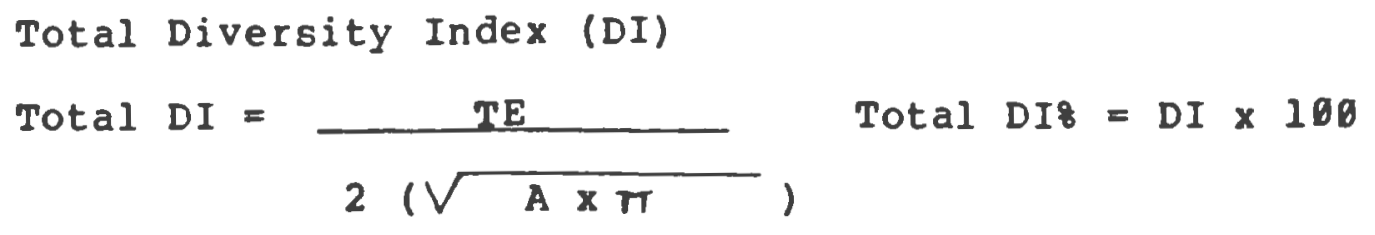

Where:

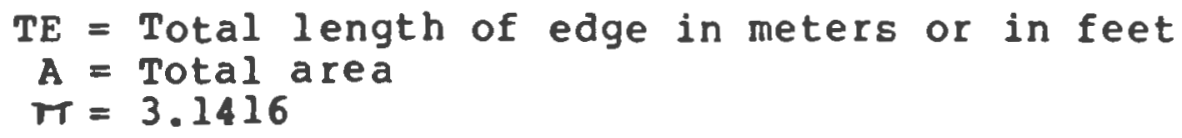

\section{Average bleck size calculation}

To calculate average habital block size, determine the size of each habitat block, using a planimeter or a dot grid, and divide by the total number of blocks. Areas with both a high diversity index and optimal average block size are preferred.

\section{Habitat of community valued species}

As with unique and diverse habitats, those of community value can be identified by planners. In fact, planners may be in a better position to do this than other professionals, because they know of the community's values. Within this category, citizens themselves are the experts.

Compilation of valuable habitats

Once valuable habitats are identified, they should be 
compiled into a spatial representation. This can be accomplished manually, by preparing maps of the same scale, and overlaying them. It can also be more precisely accomplished through the use of geographic information systems, which compile identical scale images, from digitalized natural resource data. Many states have these systems, and they are potentially accessible to local planners(Appendix A).

\section{Habitat Unit Determination}

Rather than evaluating all wildife habitat within a community simultaneously, it is useful to subdivide land into manageable units based on ecosystem dynamics and animal movement barriers.

The following habitat unit determination is based on the objective of maximizing land area available to terrestrial vertebrates, and relates to eventual land corridor system formation, once barriers and valuable habitats are identified. It is not particularly useful when planning for arboreal or aquatic animal species, but it does not interfere with planning for these species.

Watersheds are suggested as the basic unit of ecosystem, and therefore habitat analysis. Watersheds act as ecosystems, because within them energy flows and nutrients are recycled. The topographic, geologic, and hydrolic characteristics of a watershed determine the nature of soil formation, vegetation, and wildife.

within a watershed, habitats need be further divided by 
terrestrial animal movement barriers. Because maintaining species diversity, which is land area dependent, is a primary planning objective, it is essential that potential habitat area dividers be identified. Movement barriers can reduce effective habitat size, and thus reduce species diversity. Once potential barriers are identified, strategies can be employed to minimize the effect of these barriers.

Both rivers and roads pose movement barriers for many terrestrial animals. Some animals can not or will not cross certain water bodies or roads. The degree of movement restriction varies considerably with the size and behavior of different wildife species, and with the size and characteristics of the water body or road. In general, the wider the barrier, the more restrictive it will be to animal movement.

The width and flow of streams and rivers determines the degree of animal movement restrictions they pose. Stream width varies with relative location within a watershed. As streams decrease in elevation, in the lower portion of watersheds, they increase in width. The volume of water also increases with declining elevation. At higher elevations, narrow intermittent streams flow for only part of the year. Wider, lower elevation, perennial streams, flow throughout 45 the year - Therefore, perennial streams pose greater movement restrictions to terrestrial vertebrates than do intermittent streams.

Planners can identify relative widths and flow volumes, of streams and rivers in their community, through use 
of maps. Rivers can be classified as primary, secondary, tertiary, and so on, depending on their relative location to one another, and within the watershed(Figure 4). Primary streams arise at high elevations from runoff, springs, and snowmelt. Secondary streams are the product of primary stream mergers. Tertiary streams are the product of secondary stream mergers, and so on. Stream classification is useful for determining habitat unit boundaries.

For the same width, roads generally pose twice the 46 barrier of rivers . The degree of animal movement restriction depends on the width of road, construction materials, traffic flow, and the total length of road. Paved, high traffic volume roads produce a greater barrier for many animals than do unpaved low traffic volume roads . In addition, as road density per unit area increases, habitat effectiveness declines.

In a recent study on deer and elk, both utilized habitat less, as the length of road per mile of habitat increased. Habitat utilization by elk declined by only 108 as road length increased from zero to 6 miles per mile of habitat, in areas with gravel and dirt roads. Conversely, main roads, one and one half lanes wide or more, improved, in good condition, main routes of travel, with constant maintenance, showed nearly a 1008 decline under the same change in road length relative to habitat size. Narrower, less travelled paved roads caused a 908 decline in habitat utilization in the same study . 


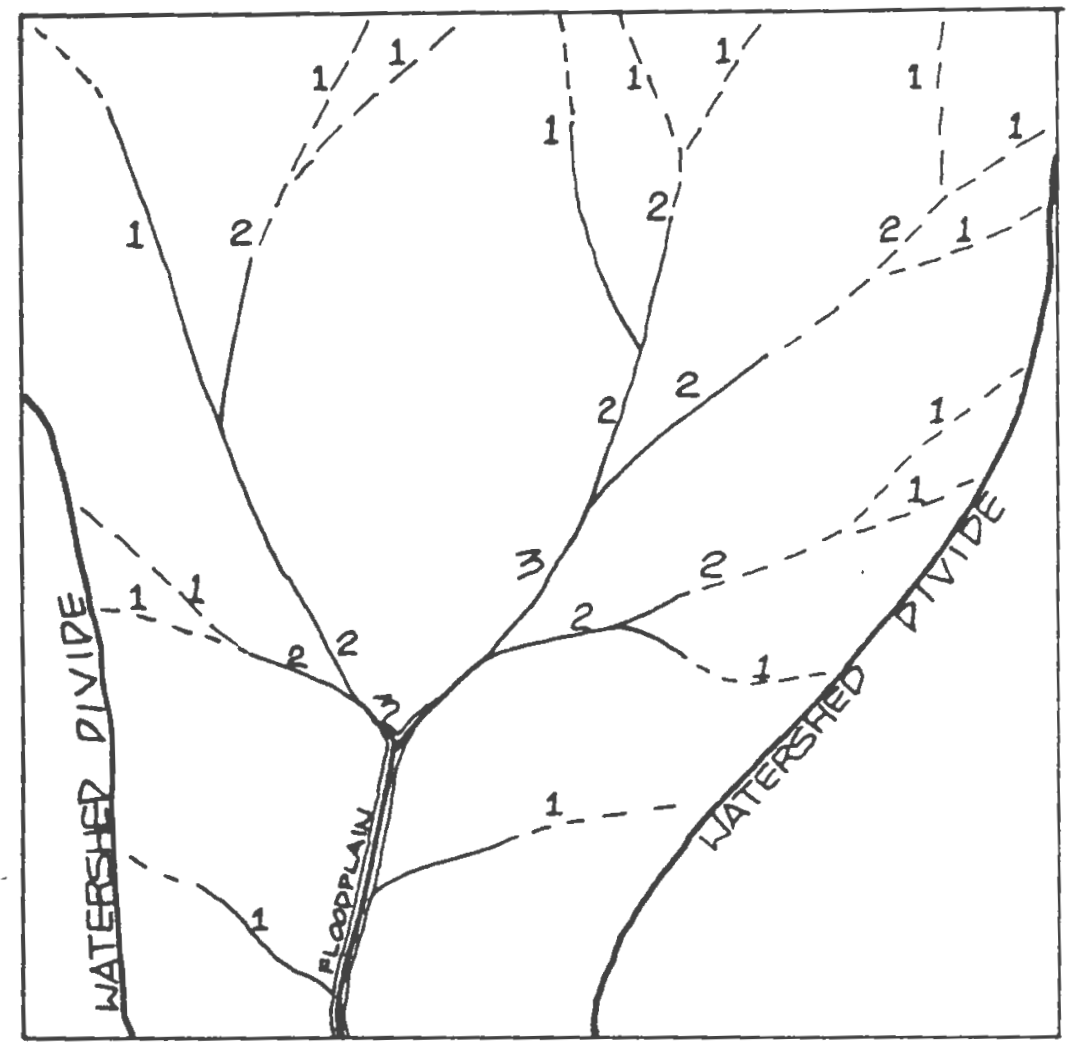

FIGURE 4: Classification of streams as primary, secondary, or tertiary based on relative location within a watershed. Primary streams (1) arise at the highest elevations. Two or more primary streams merge to form secondary streams(2). Two or more secondary streams merge to form tertiary streams(3). Stream width and floodplain development increases from primary to tertiary or higher streams. 
Road location also effects animal movement potential. Watershed divides, although serving as animal migration corridors, have a great potential for road construction. Many existing roads are built on divides. These locations are often cheaper and easier road construction sites than are low elevation sites. Road construction could sever watershed divide habitat linkages connecting one watershed to another (Figure 5)

Habitat unit boundaries should include watershed divides, busy paved roads, and wide rivers (Figure 6). In the absence of specific local data regarding the migration patterns of indigenous terrestial wildlife, or the volume of traffic on streets, the author suggests tertiary streams, and one and one-half lane or wider paved, well maintained roads as boundaries. These widths should restrict many terrestrial species. However, specific local research is recommended. The unique landscapes of individual communities should also be considered when assigning boundaries.

Planners must use their own judgement regarding what constitutes a significant migration barrier in their community. If a community is riddled with waterways, the planner may choose only the widest streams as boundaries.

The same is true for roadways. In an urbanized community, interstate highways may be the most logical habitat unit boundary. In a small community, any two lane paved road might be considered as a boundary.

Ideally, important wildife habitats and the key species $-45-$ 


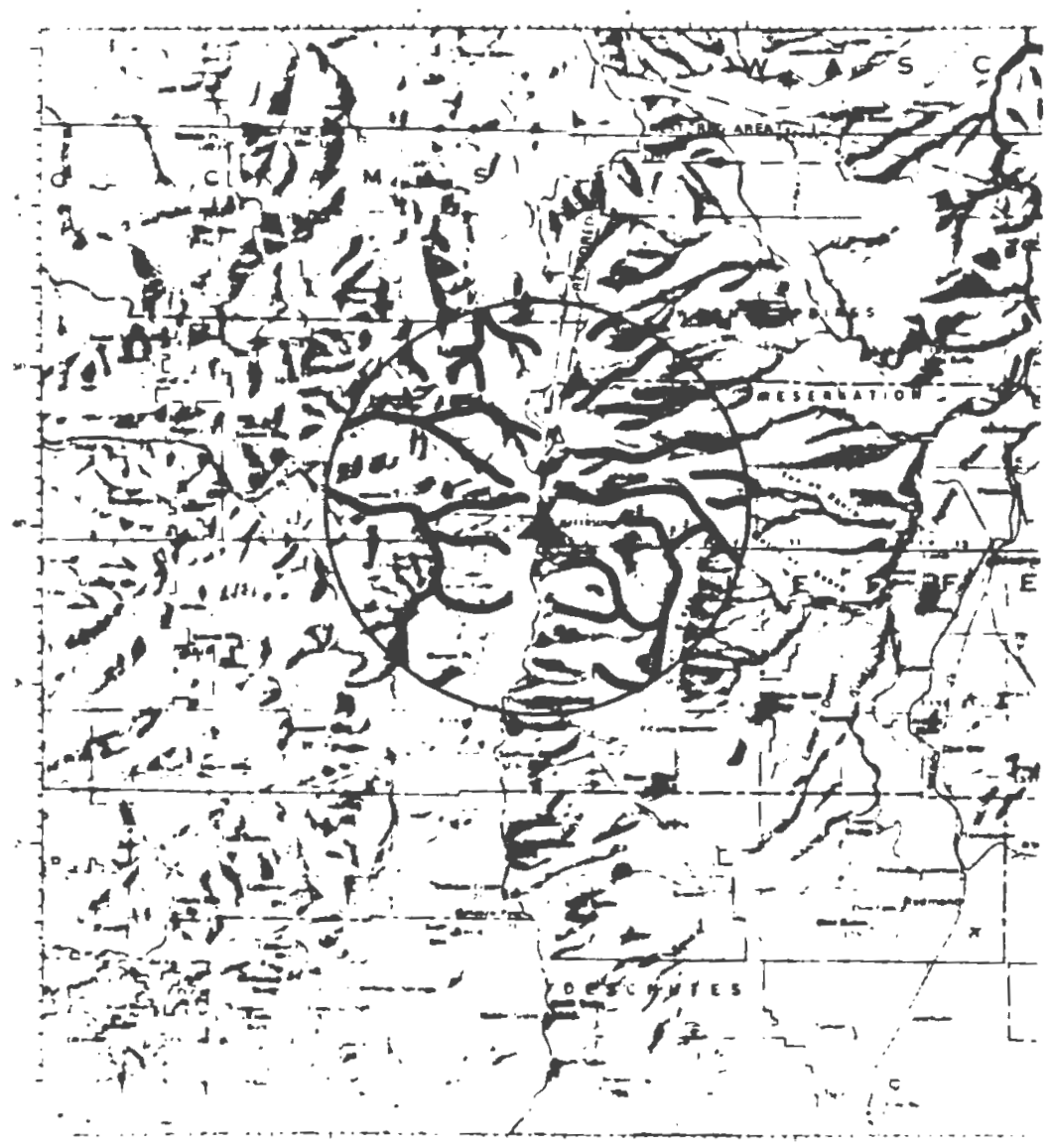

Figure 5: Rivers from one drainage juxtaposed with rivers from another drainage. Protected riparian strips along these rivers facilitate animal movement and gene flow between populations.

Source: L.D. Harris, The Fragmented Forest: Island Biology Theory and the Preservation of Biotic Diversity. University of Chicago Press, Chicago, 1984, p. 149. 


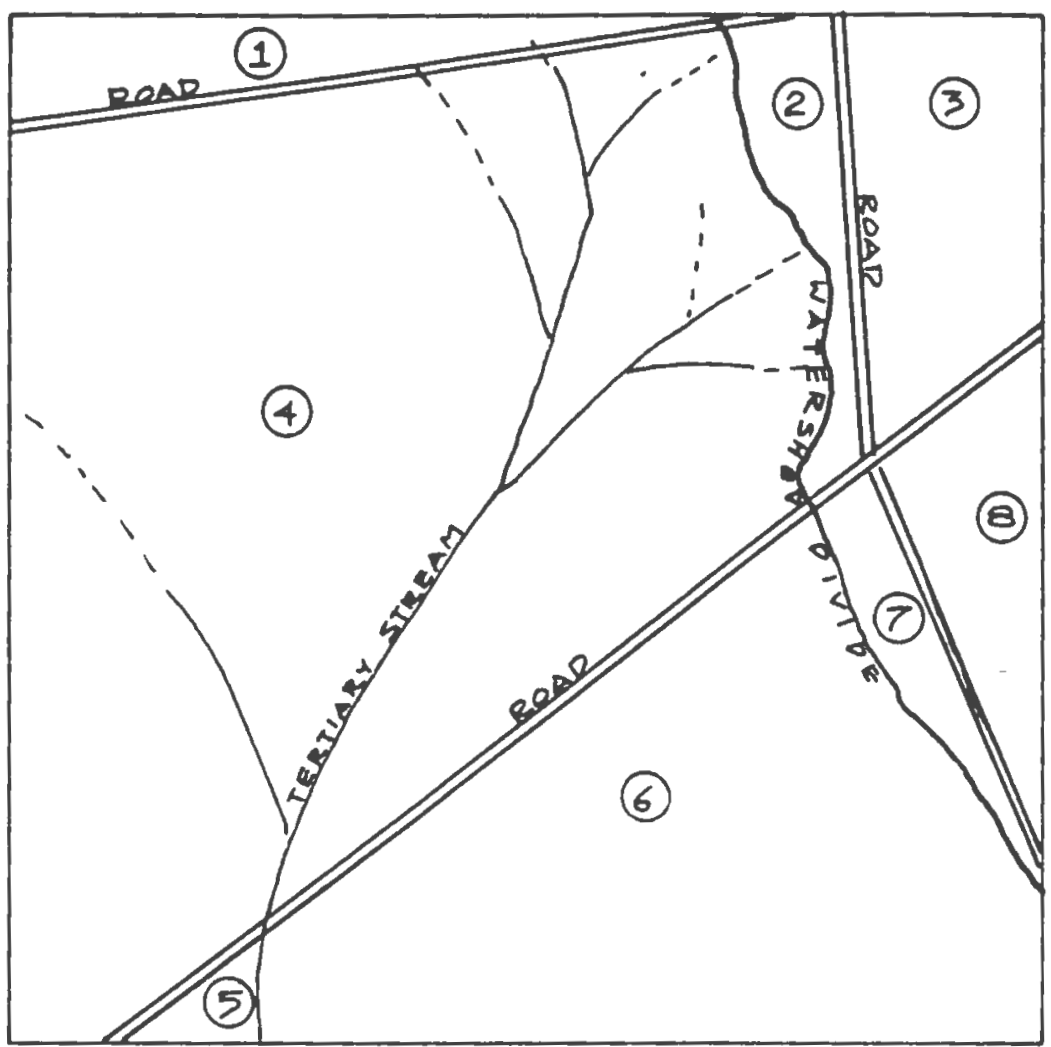

Figure 6: Determination of Habitat Units by the Intersection of watershed devides, two lane paved roads and tertiary streams and rivers. Note that while a tertiary stream is present in Habitat Unit 4 , it does not intersect any other barriers. Movement then will not be restricted through the entire habitat unit although the direction of movement is limited. 
within them which warrent protection, are identified prior to habitat unit assignment. Then realistic migration barriers can be determined, relative to the migration patterns of community valued species.

\section{Prieritization of Babitat Unit Values}

Once habitat units are delineated, and valuable preserves within them identified, each unit should be ranked according to its' wildlife value, planning value, and economic development potential. Wildlife and planning ratings will serve three functions. First, they will identify areas in which the community should focus its' protection efforts. Secondly, they will form a convenient basis for corridor system formation. And lastly, they will provide a clearly delineated management unit, in which zoning regulations and non-regulatory programs and policies can be applied. Economic development potential ratings will serve to identify possible conflicts of interest. Intrinsic wildife ratings

wildlife ratings should be based on the intrinsic value to animal species(Table 2$)^{51}$. This value includes habitat diversity, size of homogeneous habitat blocks, endangered, threatened, or rare species habitats, area of such habitats, fragility of habitats, productivity, relative location within watersheds, water supplies, and proximity to watershed divides. 
Table 2

Ten Intrinsic Wildife Evaluations, Each with a Possible score of 5 points.

Category

Possible

Points

1) Diversity Index (DI)

Bigh

Moderate

Low

5

Low

$74-99$

$50-73$

$100-124$

$>124$

$<49$

3

2) Average Habitat Block Size

Endangered 5

3) Nationally Endangered,

Threatened, or Rare Species

5) Total Preserve Area

Excluding Diverse Habitats in Acres

Threatened 3

Rare

1

$1000+$

$500-999$

$100-499$

$10-99$

$<10$

\section{5}

4

3

2

6) Fragility of system

High

Moderate

Low

5

Bigh

7) Productivity

Moderate

Low

5

4

4

3

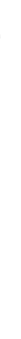

Lower Third 5 Hiddle Third 3 Upper Third 1

9) Types of Streams

Tertiary Secondary Primary

10) Number of Watershed Devide Borders

$\begin{array}{ll}3+ & 5 \\ 2 & 3 \\ 1 & 2\end{array}$

Source: Some catagories modified from F.O. Sargent and J.H. Brande, classifying and evaluating unique natural areas for planning purposes, Journal of Soil and Water conservation, 1976, 31(3), pp.113-116. 


\section{Wildlife olanning ratings}

Planning ratings should be based on the value of wildife preservation to the community, and on policy implementation considerations(Table 3) . Planning values include economic, recreational, educational, scientific, aesthetic, perceptual, and public health values. Also important to planning status, is the community's overall interest in wildlife conservation, the integrity of targeted areas, current zoning, the established significance of specific areas, and the potential for corridor system network development.

\section{Economic development ratings}

Economic development potentials should be rated for development opportunities, and optimum siting for residential, commercial, and or industrial development. Location, and access should also be considered, as should established community development policies, as articulated in the master plan (Table 4).

Economic pressures will effect even the most well concieved plan. Therefore, planning without economic development considerations is futile. Development opportunities within habitat units must be addressed in order to resolve potential development/conservation conflicts. Potential conflicts can be resolved through active negotiation between 
Table 3

Nine Wildife Planning Evaluations, Each With a Possible score of 5 Points.

1) Economic Value

High

Moderate

Low

3

2) Recreational Value

Community-wide 5

Neighborhood 3

Personal

3) Educational

Community-wide 5

Ne ighborhood 3

Personal

4) Public Health Value

$\mathrm{High}$

Moderate

Low

5

3

5) Aesthetic/Perceptual Value

Community-wide

Ne ighborhood

Personal

$$
5
$$

3

1

6) Community Interest in

$>508$ of Community 5

wildlife Conservation

25-508 3

$<258$

7) Integrity of Area

Safe $<5$ yrs

Safe 5-20 yrs

Safe $>20$ yrs

5

Rlo-20

8) Current zoning

$R 10-20$

Commercial

Industrial

R40-199

R200+

\section{1}

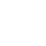

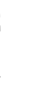

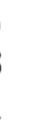

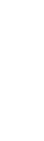

Federal

9) Established Significance
Interstate
State
Substate
Local

5
3
1

Source: Some catagories modified from F.O. Sargent and J.H. Brande (1976). 
Table 4

Five Economic Development Evaluations, Each With a Possible Score of 5 Points.

Category

Possible

Points

1) Long Term Tax Revenues

High

5

Moderate

3

Low

2) Job Creation Potential

High

Moderate

Low

5

1

3) Lack of Physical Constraints to Development.

Top 208 of sites Middle 31-798 3

Bottom 308 of sites

4) Location and Access

Good

Fair

Poor

5

High

Moderate

Low

5) Area Development in Accordance With Master Plan

5

3 
development and conservation interests . Mutually acceptable outcomes are possible through planner mediated negotiations.

\section{Explanation of table categories}

In the intrinsic wildife rating system, the first two categories relate to natural diversity based on habitat diversity.

1) The diversity index indicates habitat diversity resulting from the edge effect.

2) The average habitat block size indicates the optimum average block size for the highest sustainable species diversity.

The next 5 categories relate to wildife habitat value based on the presence of endangered, threatened or rare species, and/or on highly productive, unique or irreplaceable habitats.

3) Nationally endangered, threatened, or rare species habitat indicates areas where nationally protected species occur. Preservation of these areas promotes national as well as local conservation interests.

4) State endangered, threatened, or rare species habitat indicates areas where state protected species live. Preservation of these areas promotes state as well as local conservation interests. State protected species may also be nationally protected.

5) Total area of endangered, unique, and or community valued 
habitats indicates the total size of a preserve area within a habitat unit. Highly diverse areas, as determined in the first 2 categories, should not be included in the area determination, as they are evaluated separately.

6) The fragility of the system indicates the irreplaceability of habitat. Habitats in later stages of succession are often more difficult to replace than early successional habitats. Some habitats are intolerant to human disturbance, such as salt marshes, and alpine areas.

7) Productivity indicates the growth rate of vegetation per unit area, per unit time. It is usually expressed as killograms per meter squared per year $(\mathrm{kg} / \mathrm{m} / \mathrm{yr})$. Productivity varies with the type of ecosystem. From least to most productive are deserts, boreal forests, grasslands, cultivated lands, cold deciduous forests, warm temperate mixed forests, rain forests, freshwater wetlands, and salt marshes. Productivity in terms of wildife populations also depends on the type of vegetation found within a particular ecosystem. Areas containing vegetation of high wildlife food value will be highly productive for wildife. Appendix B lists wildife food values for various regions of the United States.

The last 3 intrinsic wildlife categories relate to wildlife habitat values based on location within the watershed, and proximity to streams. 8) Location in the watershed indicates the access to large streams, which support a wider array of wildlife species 
than do small streams. Stream size and water quantity increases from the top to the bottom of watersheds. 9) Types of streams within a habitat unit also indicates access to water sources. Again, the larger the stream, the higher the potential wildlife value.

10) Watershed divide location indicates the possibility of inter-connecting preserve areas with corridors. Because wildife use watershed divides as migration corridors their existence effectively increases preserve area size.

In the wildife planning rating system, the first 6 categories indicate community wildife values and commitment to wilalife conservation.

1)Economic values indicate the income generated by the sale of wildife recreation or education related equipment, and by ancillary service provision. Economic values also indicate potential costs the community might acrue if wildlife preserve areas are developed. An example is the cost of flood storage development, if wetlands that provide natural flood storage are destroyed.

2) Recreational values indicate areas used by community members for wildife recreation activiites. Examples are nature study, photography, hunting, and fishing. 3) Educational values indicate whether the area is or could potentially be used as part of the community's primary or secondary education system.

4) Public health value indicates the degree in which preserve areas function as pollution abaters and monitors, and stress 
relievers. The less conservation land which is available, the more valuable the remaining undeveloped land is for the public's health.

5) Aesthetic and perceptual values indicate which areas the community believes are valuable instinctively. More visible wildife species will be considered more valuable than less visible species.

6) Community interest in wildlife preservation indicates consensus regarding action in wildife conservation.

The next 4 categories relate to the need for planning action and implementation.

7) Integrity indicates the degree of development pressure a habitat unit faces. Preserve establishment is most imperative in areas threatened with immediate development. Although those areas threatened within 5 years score the highest points, those threatened within 10 years need immediate consideration as well. Comprehensive preservation schemes may take a long time to implement. 8) Current zoning indicates the potential threat to wildlife habitat. Threats imposed by commercial and industrial development vary considerably depending on the specific development design. They may or may not be more harmful than residential development. Dense development results in the most habitat loss, and is therefore most threatening to wildlife.

9) Established significance indicates the degree of interagency cooperation and support which can be anticipated. 
In the economic development rating system, categories relate to the potential development pressures an area faces, either from zoning, community policies, or market demands, and the desirability of development to the community.

1) The first economic development category indicates the long term tax revenues that development could bring into the community. This determination is somewhat hypothetical, but current market conditions could give planners some indication of potential revenues.

2) Jobs created by development indicates whether development in this area would stimulate the community's economy, by supplying jobs for citizens. Again, this determination is somewhat hypothetical and instinctive, rather than empirical.

3) Lack of physical constraints to development indicates which areas are best suited to development based upon physical land features such as soil, groundwater, topography, geology, and vegetation. If land, which is free from physical constraints is limited, this land is particularly valuable for community development. Top 208 of sites means that the majority of land within the habitat unit possess fewer physical constraints than 808 of the community's potentially developable lands. This consideration could also effect potential town revenues, as installation of town supplied infrastructure is more costly when particular physical constraints are present. 
4) Location and access will effect the economic value of land and determine the success of development projects. Commercial and industrial developments in particular, rely on good location and access.

5) Area development, in accordance with community master plan indicates whether or not development within the habitat unit has been a stated community goal. The 4 previously mentioned economic development categories are probably considered in the formation of community policy regarding the optimum direction of community growth.

\section{Corridor System Development}

Once habitat units are prioritized, they can be incorporated into a community-wide corridor system. Corridors are habitat bridges connecting one preservation area to another, which allow for plant and animal migration. Corridors effectively increase preserve size by forming networks. Land corridor development in conjunction with existing wetland and stream corridors will produce an effective animal migration system for aquatic and terrestrial species alike.

As already stated, large land areas will support a more diverse array of wildife than small areas. And species diversity should be the primary rational objective of any local planning strategy. Because isolated preserve areas are likely, where privately owned lands predominate, connection of these lands into a system is imperative to increasing effective land area. 
The corridor system plan should include 4 major features. These include: 1) corridors connecting isolated preserve areas within habitat units. 2) corridors connecting preserve areas across habitat unit boundaries. This means across roads, and watershed divides. 3) corridor development parallel to river systems. and 4)corridor widths which vary with target species and watershed characteristics.

Corridor systems within habitat units require little expense. They can be maintained by controlling development within designated corridors. This control could be furnished by increased open space requirements, and subdivision design requirements which permit animal migration. The promotion of cluster developments, which preserve more open space area than conventional subdivsions, and residential compounds, which permit dirt roads and also preserve open space, is recommended in valuable wildlife habitat areas (Appendix C).

Corridor development across road barriers is more complex and expensive. As mentioned previously in this chapter, traffic volume relates positively with animal movement restriction. So, strategies which decrease traffic volume could be employed to minimize the effect of roads as migration barriers. Speed limit reductions, and strategically placed stop signs could slow down traffic, thus reducing road kill frequency. Lack of road maintenance along travel corridors, in combination with improved maintenance along alternative travel pathways could encourage motorists 
to frequent alternative roadways. This measure would also minimize animal movement restriction in critical areas.

Finally, creation of road underpasses or overpasses is a costly, but effective alternative. Road underpasses, or tunnel construction, would allow animals to walk over roadways without encountering traffic. These walkways would be surfaced with the same vegetation as the adjacent areas. Overpasses, which bridge over valuable wildife travel corridors, would also separate animals and automobiles, yet permit movement of both.

Maintaining open corridors across watershed divides is possible by limiting road construction in these areas. Corridors across watershed divides allows genetic interchange between watersheds to occur. Corridors should be oriented perpendicular to watershed divides, and parallel to streams, so that animals can travel along streams to watershed divides, then cross over to adjacent watersheds. Once across watershed divides, animals can resume migration parallel to the next watershed stream system.

The optimal corridor design will utilize existing water channels. Wildife species concentrate near creeks, streams, and rivers(riparian areas). Riparian areas function not only as corridors, but act a preserve areas as well. Riparian areas tend to support hardwood forests which provide seeds and fruit for wildlife. Softwood forests are less productive for wildife food sources 56 .

Corridor width should coincide with elevation differe- 
nces, and the corresponding wildlife value differences. Lower elevation sites, associated with wider streams, are richer in species. These sites receive water, nutrients, and energy from upland and upstream systems - Corridor width should increase, as stream width increases. Larger animals, such as carnivores, require large land areas. They are associated with wider streams than are smaller animals(Figure 7$)^{58}$. Large animals require large individual territories, and would be restricted by narrow corridor widths.

How wide should the travel corridor be? Although still debated, many communities require buffers from 25 to 250 feet along creeks, streams, and rivers. But, buffers of even 300 feet may be too narrow to serve as effective corridors for some large mammals. A good rule is to establish minimum buffers for corridor systems, of 100 feet or more, and add to the requirement depending on a particular target species, or upon stream width.

Corridor width requirements can be determined for a particular species, targeted for protection because of its' endangered, threatened, or rare status, or community value. One strategy is to establish corridor width requirements based on the home range size of the target species. Home range is the area normally traversed by an individual animal or group of animals during activities associated with feeding, resting, reproduction, and shelter-seeking . Home ranges have been determined for many mammals. A mathemati- 


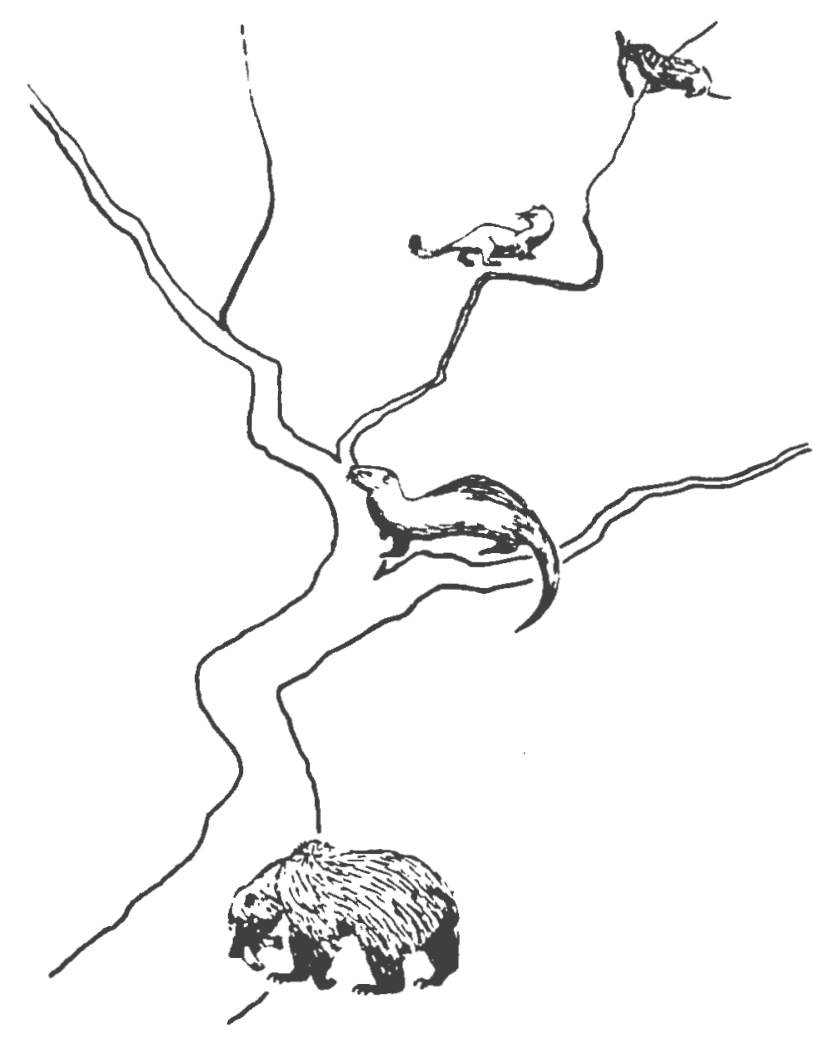

Figure 7: Association of different-sized carnivorous mammal species with stream order and typical food particle size in accordance with the streamcontinuum concept. From top to bottom are pictured a shrew, a mink, an otter, and a grizzly bear.

Source: L.D. Harris, The Fragmented Forest:Island Biogeography Theory and the Presrvation of Biotic Diversity University of Chicago Press, Chicago, 1984, p. 143. 
cal relationship between body weight and home range size for herbivores has been determined (Table 5) .

Table 5

Relationship between home range and body size, for herbivores, omnivores, and carnivores, and possible corridor width requirements, assuming square shaped home ranges, and home range width as corrdor width.

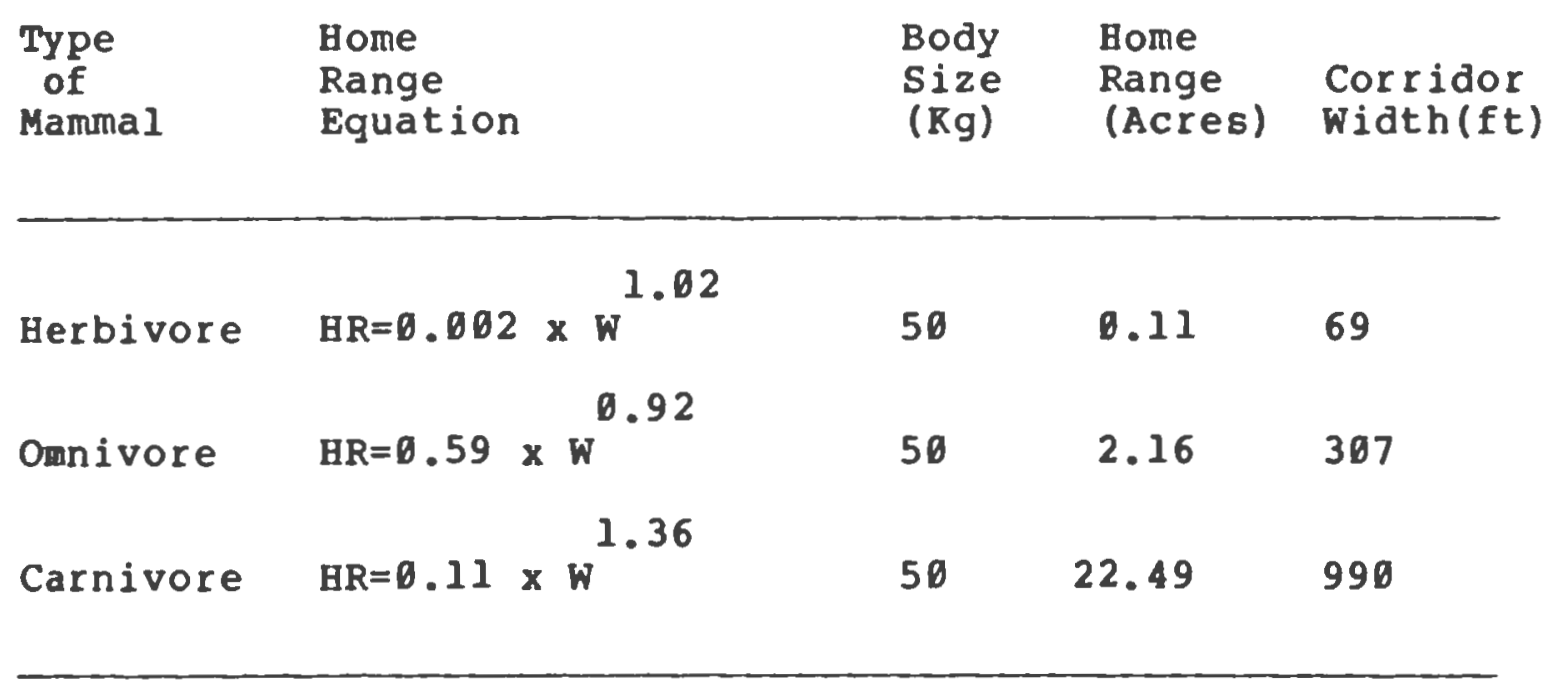

$\mathrm{HR}=$ home range, and $\boldsymbol{W}=$ weight of animal.

Source: A.S. Harestad and F.C. Bunnel, Home range and body weight: a re-evaluation, Ecolegy, 1979,

(60) pp. 389-402 
Carnivores require the largest home ranges, followed by omnivores and herbivores. The largest targeted carnivore would determine the largest corridor requirement. Once home range requirements are determined, corridor widths can be determined by assuming that home range area in approximately square shaped, and that corridor width should equal one side of that square(Table 5). Use of this method would indicate the need for very wide corridors for large omnivores and carnivores, and moderately wide corridors for herbivores. For instance, a $50 \mathrm{~kg}(110 \mathrm{lb})$ carnivore would require a 990 foot wide corridor, whereas an herbivore of the same size would only require a 69 foot wide corridor. The home range method would be useful to planners who have access to information regarding species distribution in their community. No mathematical equation has been determined to estimate the relationship between maximum animal body weight and stream width for herbivores, omnivores, and carnivores. This information would be very valuable to planners.

\section{Il lustration of Wildife Planning Method}

The following example illustrates the habitat identification, and corridor system development method. A section of a U.S.G.S. Quadrangle map of Tiverton, Rhode Island is used. The purpose of this example is to provide a visual representation of the planning process, not to provide an actual wildife plan. In actual planning practice, the land 
area would typically be much larger than this example, and the data base for the plan would be more extensive.

The mapping process illustrated in this example includes: 1) identification of endangered, threatened, or rare species habitats, unique and irreplaceable habitats, and habitats of species valued for recreational, aesthetic, educational, scientific, or economic reasons(Figure 8 ), 2) highly diverse habitats(Figure 9 ), 3) a compilation of valuable habitats(Figure 10), 4) habitat unit identification, using watershed divides, roads, and tertiary or higher order streams or rivers as boundaries(Figure 11), and 5) a corridor system which includes intra-habitat unit corridors, inter-habitat unit corridors, corridors parrallel to river systems, and variable corridor widths(Figure 12).

For ease of representation, only unique and irreplaceable habitats are illustrated(Figure 8). Endangered, threatened, or rare habitats, or those valued for recreational, aesthetic, educational, scientific, or economic reasons are not illustrated in this example. In actual planning, these important habitats would also be separately identified and mapped. 
Figure 8: Identification of unique and irreplaceable habitats which consist of wetlands, open water bodies, and unique forested areas.

legend: $\quad$ Wetlands

(3) surface water bodies

(1) unique forested areas 


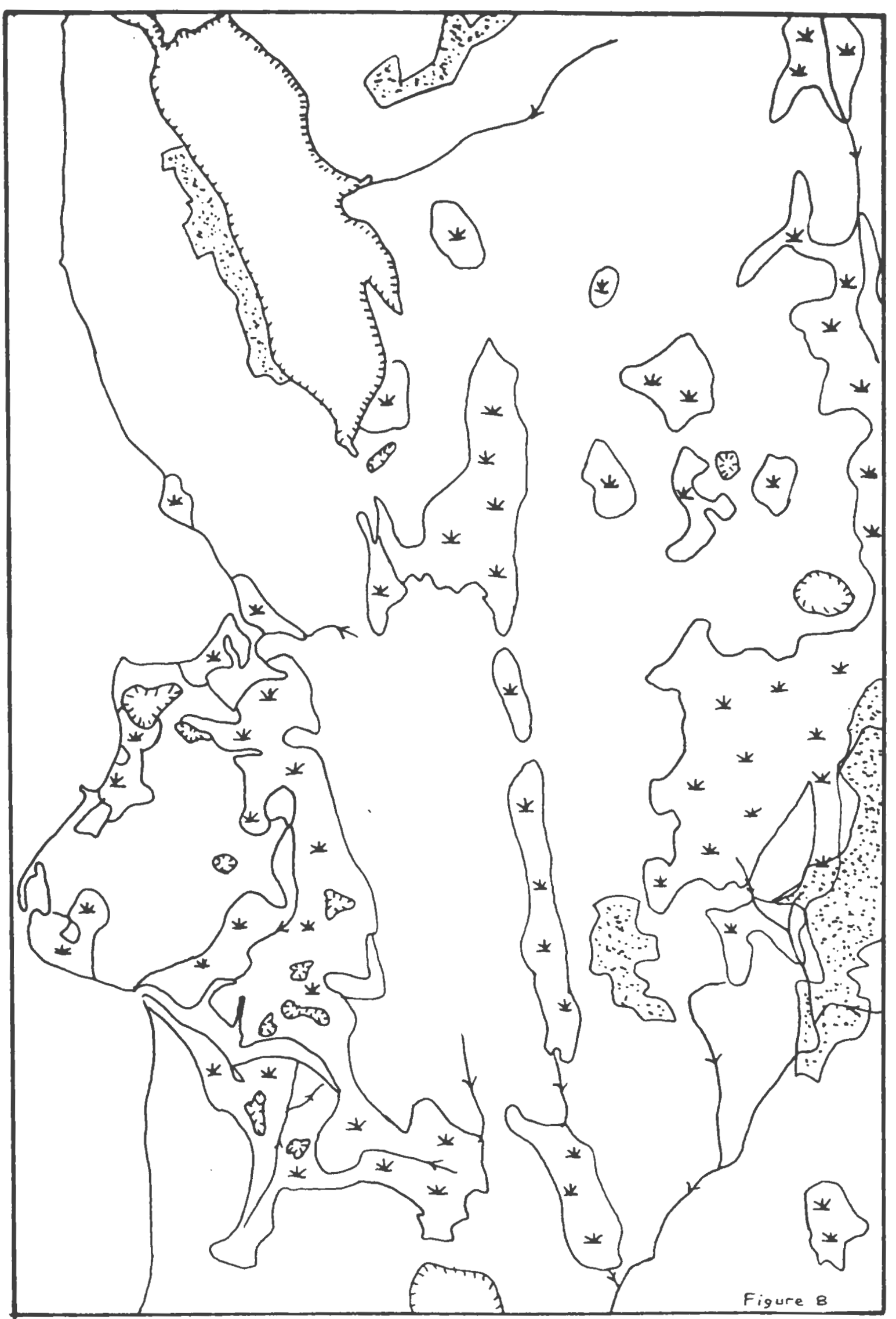


Figure 9: Habitat diversity as illustrated by habitat edges. Each area represents a different habitat type. As one square inch equals approximately 91 acres, and the optimal average habitat block size is from 74 to 99 acres, blocks of nearly one inch square are preferred for protection. Most of this diverse habitat is located in the lower portion of the figure.

legend:

23 habitat edge 


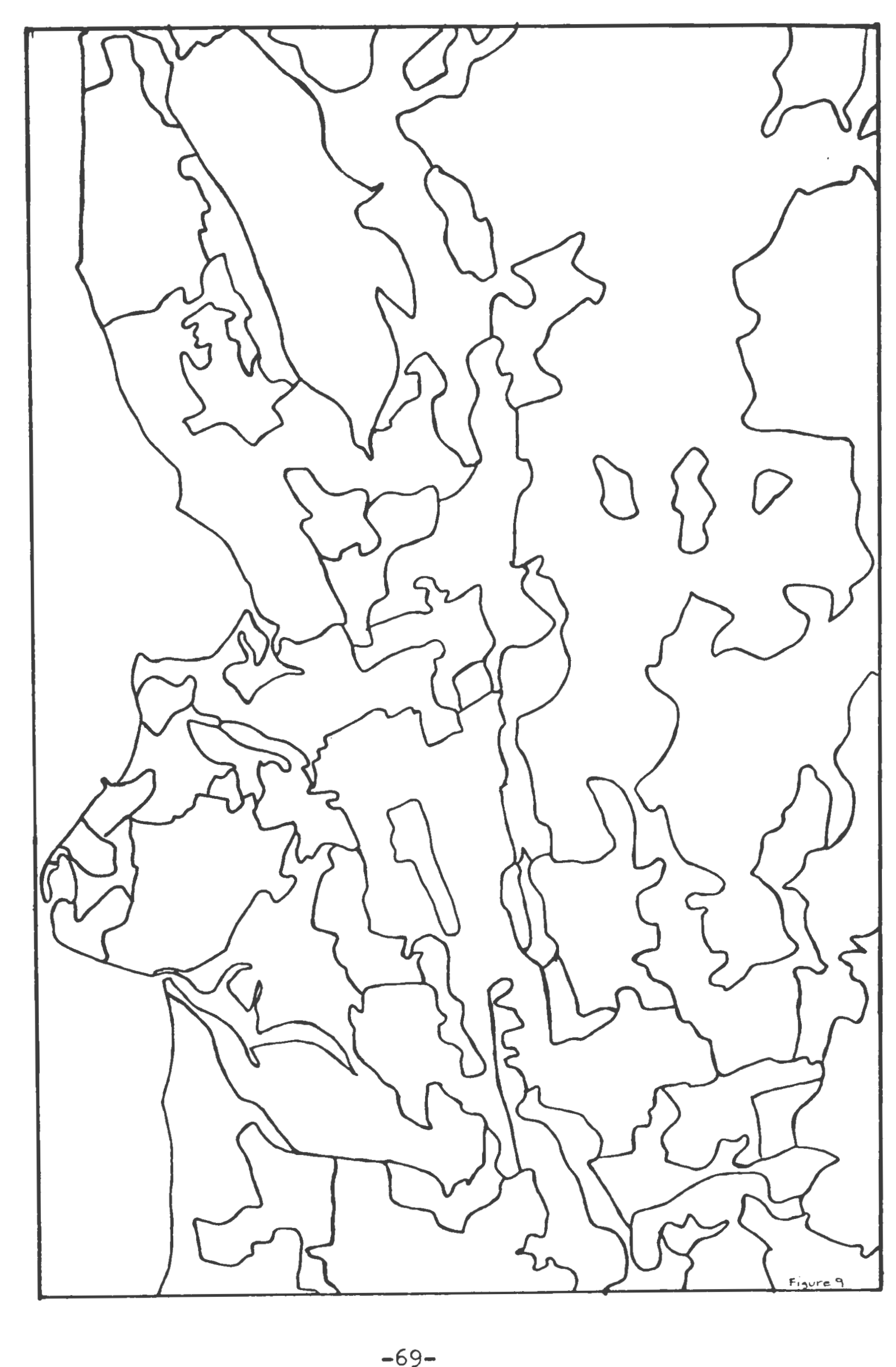


Figure 10: Complilation of valuable habitats. Unique and irreplaceable habitats are overlayed on diverse habitats. Much of the unique and irreplaceable habitat overlaps with diverse habitats. Areas with both uniqueness and diversity are more valuable than areas with either. 


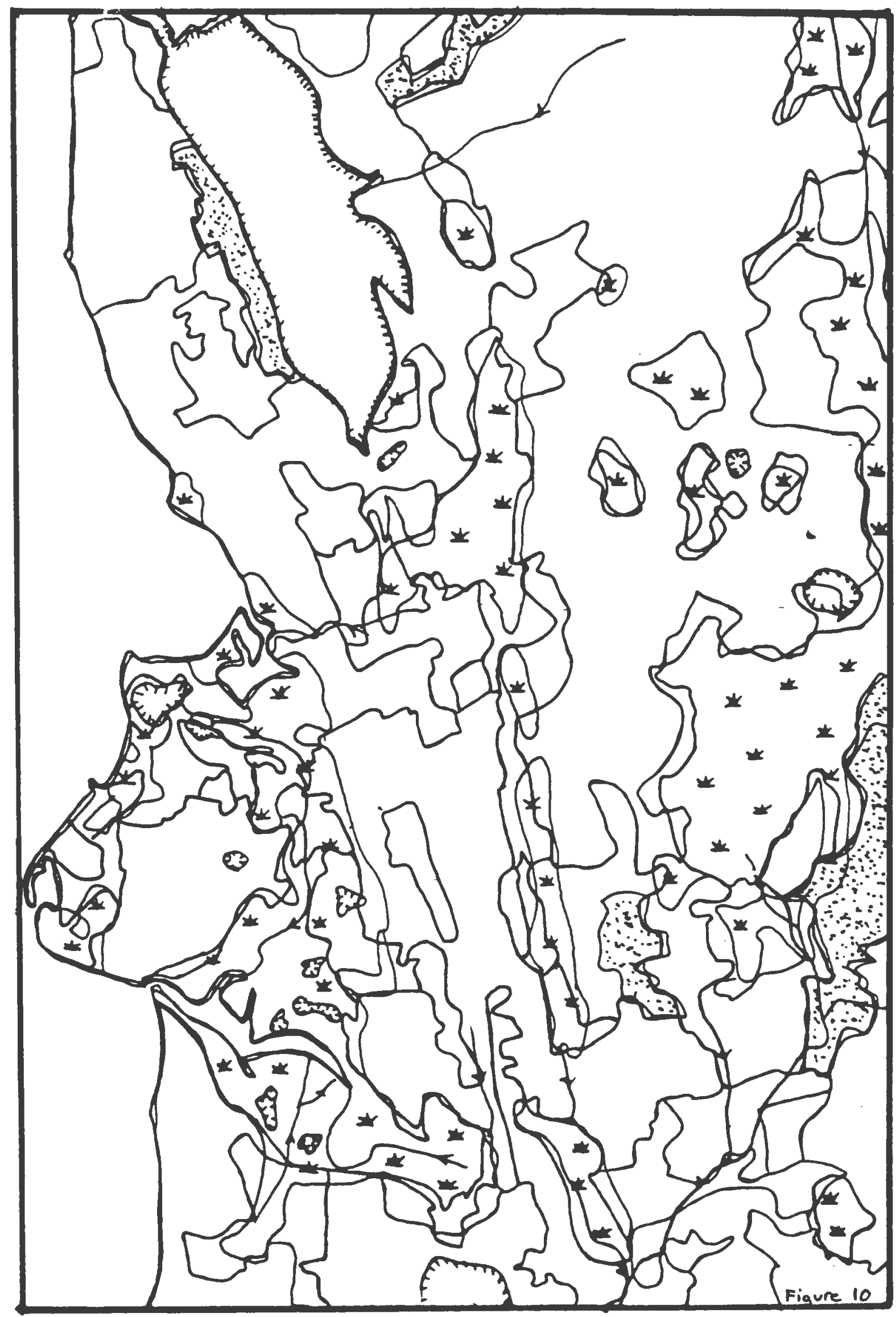


Figure 11: Habitat Units as determined by movement barriers, and watershed divides. The Sakonnet River is the only river which qualifies as a boundary. Nine separate units are delineated. Units 6 through 9 are too small or of insignificant value to warrent ranking.

legend: $=$ roads
(8) watershed divides 


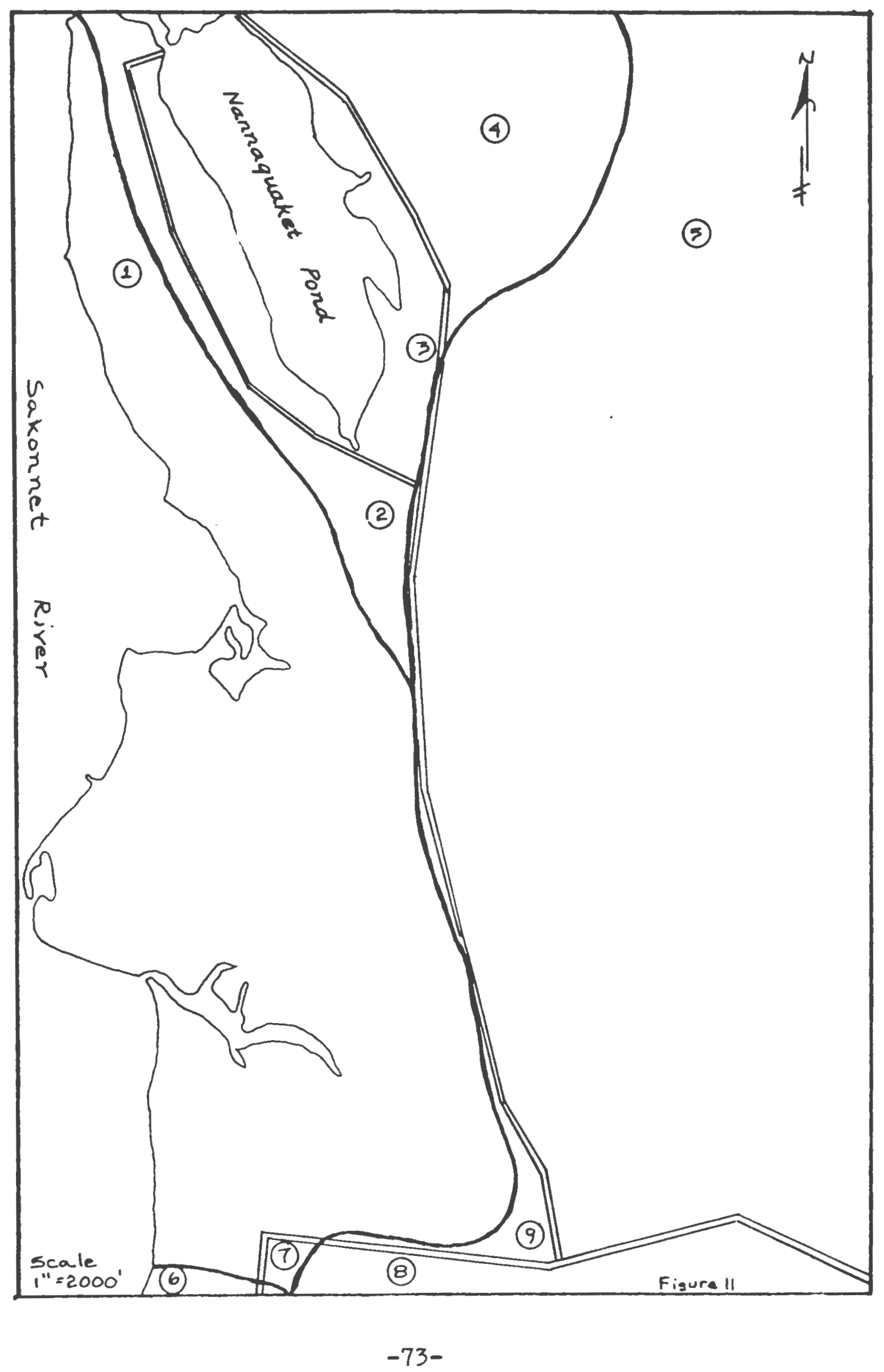


Figure 12: Preserve areas and corridor systems, overlayed on habitat units. Road barrier mitigation strategies are proposed where high ranking habitat units are juxtaposed, and preserve areas bisect roads.

legend:

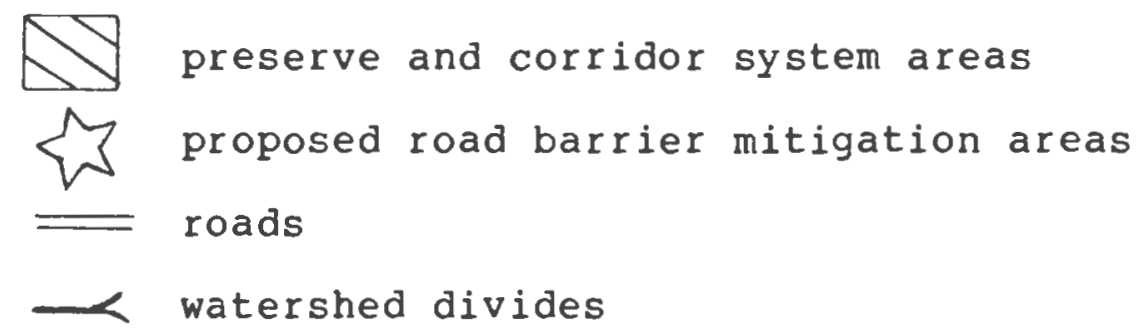




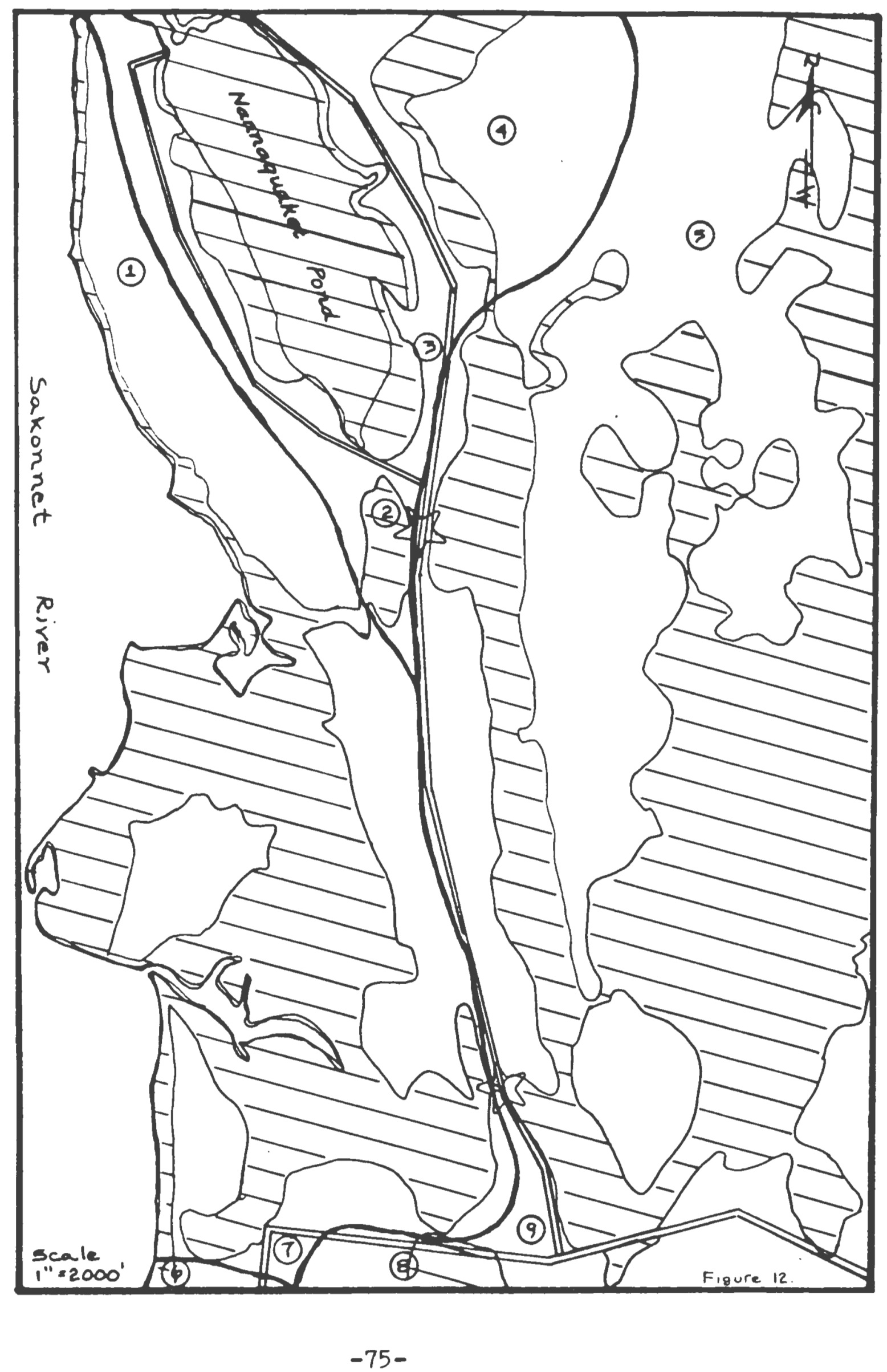


The first four processes involve mapping variables and overlaying them. The fifth, corridor system formation, requires the planner's personal judgement. Not all valuable land within a community can be preserved, particularly if valuable wildlife resources dominate the landscape. So, some valuable areas must be overlooked in order to concentrate preservation efforts on the most valuable habitats. This applies to corridor and preserve development within as well as between habitat units. Preserving areas which satisfy a number of criteria is optimal.

The purpose of ranking habitat units, rather than ranking only individual preserve areas, is to indicate where corridor connections across existing road systems should be proposed. Also, some regulations may be applied more easily to clearly delineated habitat units, than to preserve areas individually.

\section{Wildife Preservation as a Master Plan Element}

It is important to incorporate wildlife resource protection as part of the community's comprehensive or master plan. This will insure that : 1) the community's goals regarding wildlife preservation are clearly articulated. 2) the legal framework for wildife zoning regulations is satisfied. 3) specific plans and implementation policies for wildlife conservation are determined. and 4) long term as well as short term wildlife planning objectives are considered. Once a wildlife plan is established, regulatory and 
non-regulatory strategies for implementation can be employed. 
CAAPTER FOUR - IMPLEMENTATION STRATEGIES

\section{Regulatery}

Regulatory strategies include zoning and subdvision regulations. Zoning is the most versatile and effective means to protect natural resources such as wildife. zoning for ecological protection has been wpheld as a valid local public purpose. And maintaining species diversity is critical to ecological stability. As zoning powers are delegated by states to local governments, specific authorities vary considerably from one state to another.

Planners should review relevant state enabling legislation before undertaking non-traditional or innovative zoning strategies. Some localities are authorized to exercise home rule, while others must derive all zoning powers from specific enabling legislation. A lawyer with an environmental, land-use, or planning law background, is helpful when drafting zoning ordinances.

The taking issue must always be addressed in restrictive zoning regulations. As with all ordinances, protection of the public health, safety, and welfare should be dealt with. Provisions for landowners with undue hardships posed by regulations should be included in ordinances. zoning regulation

Four basic forms of zoning ordinances are common. They are: 1)district, 2)environmental impact, 3) single purpose, and 4) growth control ordinances. Of these district 
ordinaces would best apply to entire habitat units, as described in this report. Within habitat units, environmental impact statements could be required when critical habitats are in jeopardy. Single purpose ordinances, like environmental impact statements, leave much of the identification and assessment up to the developer. Growth control ordinaces, used in conjunction with other types of ordinances can protect wildife for extended periods of time.

District zoning applies to areas predetermined by the municipality. Typical district zoning for natural resource protection involves overlay zones, which follow the boundaries of some particular preserve area. This zone may be difficult to delineate, as boundaries are not clear cut. This is why habitat units are convenient land delineations for zoning purposes. Habitat units can be clearly delineated, as rivers, roads, and watershed devides are undisputable landscape features, which will not change appreciably. Communities using habitat units as zoning districts, still have the option of applying overlay zones to critical areas within habitat units.

Examples of district zoning ordinances include open space conservation, floodplain, wetland, and corridor system ordinances. Model ordinances can be consulted in Appendix C. Protection of these areas protects wildife. For example, the Open Space District Regulations of Palo Alto, California, include wildlife habitat conservation as an objective(Appendix C). This ordinance permits agricultural 
uses, botanical conservatories, wildlife sanctuaries, and one family dwellings within the district.

Another important model ordinance, the Floodplain and Wetlands Protection Ordinance of Oakland County, Michigan, specifies one purpose, as the prevention of damage to wildlife habitat. Because wetlands are valuable wildlife habitats, and floodplains serve as natural animal migration corridors, their protection is important for both preserve and corridor system development(Appendix C).

To further the goal of corridor system development, Dallas, Texas enacted a Corridor Development Controls ordinance. Land within the designated corridor area requires different setbacks, and building heights, in order to increase open space (Appendix C).

Some of the more progressive wildife protection ordinances have emerged from western localities. In these regions, big game animals are present in large numbers, and hunting and wildife recreation contributes significantly to the economy.

For instance, the Town of Jackson, Wyoming requires that all wildlife areas identified by the Division of Wildlife, U.S. Fish and Wildlife Service, or the Wyoming Game and Fish Department, be dedicated to the public in the platting process. No development is permitted on brush slopes in mule deer winter ranges, on elk movement corridors, within 300 yards of bald eagle or osprey nests, or in riparian habitat within 50 feet of a creek. Fences must be 
built in conformance with Game and Fish regulation, and access roads must be constructed parallel to creeks, to maintain movement corridors for big game animals. The regulations prohibit development in critical winter habitats, migration routes, or breeding areas as recommeded by the Game and Fish. In addition, Game and Fish recommendations must be sought and incorporated into developments in critical areas, if allowed(Appendix C).

Another western area, Boulder County, Colorado, has adopted a mandatory cluster zoning policy for significant wildlife habitats . Teton County, Wyoming also encourages clustering of residential development to protect wildife habitats and migration routes(Appendix C). Al though clustering is a type of subdivision development, zoning can designate where cluster subdivisions should occur. Clustering means reduced subdivision lot sizes, which accomodate more open space than would conventional subdivisions. Open space is usually commonly owned by homeowners.

Boulder County requires that 758 of the land in a cluster subdivision must remain in open space 62 . This open space requirement is high relative to other cluster zoning ordinaces(Appendix C). Still, this is the type of aggressive approach necessary to save many animal species facing local extinction.

single purpose ordinances require a specific performance standard for development, or require protection measures when a particular feature is present. They are site 
specific. The responsibility for identification and mitigation in with the developer.

Examples of single purpose ordinances enhancing wildlife habitat are those requiring indigenous landscaping, or landscaping containing productive wildlife foods. Teton County ordinances prohibit the disruption of wildlife habitat or migration routes (Appendix C).

Environmental impact ordinances are also site specific, but are more general in scope. As with single purpose ordinances, the developer is usually accountable for the assessment. Clear municipal specifications of what impacts need be addressed is important. Environmental impact ordinances are expensive and time consuming to enforce. However, they may be useful in particularly sensitive situations, such as where endangered species habitats are involved (Appendix C).

Growth control ordinances can prevent unconformity with community character, and uncontrolled urban sprawl. Leapfrogging developments, which disect wildlife habitat, can be controlled by these ordinances.

A particularly valuable growth control ordinance is the transfer of development rights(TDR). This allows the transfer of eligible residential building lots, or dwelling units form one tract of land to another. The Transfer of Dwelling Units Ordinance of Southeast, New York specifies that transfers can occur for the purpose of reserving permanently tracts of land having assets for park, recrea- 
tion, conservation, and other open space purposes(Appendix C).

\section{Subdivision requlations}

Subdivision regulations apply to the platting of land into subdivisions, road layout, and lot design standards. They also apply to public sites, and open space requirements within a subdivision. Mandatory open space or park land dedications as part of the subdivision process, benefit wildlife by conserving habitat. Most open space dedication requirements do not specify what land is to be preserved.

Specifying wildlife habitat features to be preserved in the dedication process is possible. Habitats containing highly productive wildife foods should be preserved over less productive habitats(Appendix B).

Corridor systems can also be maintained by specifying open space design within subdivisions. One approach is to reguire two major open space corridors running perpendicular to one another, meeting near the center of the subdivi63 sion. While this requirement is stringent and inflexible, it does prevent entrappment of habitat by development. Requiring access roads parallel to streams would also help maintain reparian corridors. Subdivision designs should not

[entrap wildife. They should allow connectivity between intra-subdivision open space and the surrounding landscape. The particular orientation of open space should complement the corridor system plan. 


\section{Non-regulatory}

Numerous non-regulatory approaches to wildife conservation have been employed by planning agencies, non-profit organizations, and individuals. While the main emphasis of this report is on zoning, some of the more popular land preservation strategies warrent mentioning. Communities can directly run or encourage non-regulatory programs. Most involve landowner incentives, or purchase of conservation lands or easements.

Conservation land may be aquired by fee simple purchase or by purchase of one specific right or interest, such as a right of way, the right to develop, or an easement. A conservation easement is an agreement that some specific portion of land will be preserved. Easements may run with the land and apply to subsequent owners . Purchase of development rights applies to an entire property.

Land may also be donated. Federal income tax provisions provide incentives for donations, by permitting the deduction of charitable gifts from income during the five years after donation and by excluding appreciation in the value of donated property from the donor's taxable income.

Another alternative, land banking, has been very successful in Nantucket, Massachusetts. The Nantucket Land Bank is funded by a 28 tax on all island real estate transactions. From these funds, the Bank is empowered to aquire beaches, wetlands, aquifer recharge areas, moorlands, heathlands, and other land preventing urban sprawl. In 


\section{6}

1984 , the Bank yielded $\$ 40,000$ per week . Real estate is booming on Nantucket, and housing prices are high. Community support for the program is high as well.

Communities less wealthy than Nantucket might find tax incentive programs more fruitful. Tax incentive programs either administered locally of by States can preserve conservation land. These programs permit lowered assessment values for farm, forest, or open space land, in exchange for short or long term commitments to leave land undeveloped. They usually penalize landowners who withdraw their lands prematurely. The effectiveness of taxation incentive programs depends on landowner commitment, land development pressures, withdrawl penalties, and communication between landowners and administrators of the programs.

A number of different approaches can be applyed simultaneously. In addition to designating wildlife habitats on the County's comprehensive plan, Boulder County has employed a variety of tools - conservation easements, public purchase, and cooperative management agreements to protect 67 designated localities. Although there is no County law expressly forbidding building in designated wildlife areas, the County planning staff monitors proposals with an eye to saving these spots from development.

An exciting aspect of Boulder County's wildlife planning venture, is the fact that local residents volunteered over 5,000 man hours of research and field time during a one 68 year period . Volunteers provided field research to 
identify the exact whereabouts of endangered, threatened, or rare species, those with a long term local population decline, those found in a narrow range of habitat types, and those vulnerable to a large population loss, because of high concentrations in specific locations.

One innovative non-profit organization, the colorado Open Lands(COL), has exercised entrepreneural land preservation techniques. They have coordinated private and public interests. One 3,200 acre cattle ranch was saved from becoming a 1600 lot subdivision, through purchase of the land, with the help of a private company, subdivision of the land into 5 ranches, and the establishment of a covenant running with the land prohibiting further de velopment. Five home sites were permitted. Each ranch had a share of valuable range land and each al lowed movement easements for the other four.

While incentive and cost sharing programs are ideal, and many landowners resist regulation, the combination of non-regulatory and regulatory approaches is preferable for long term planning. Incentives work best in well educated, affluent, and conservation minded communities, such as Boulder County, Colorado, or Nantucket, Massachusetts. Some communities may not have the funds to offer incentives, or development opportunities and economic forces outweigh incentives. In these communities, regulatory approaches should take precedence.

What is most imperative, is that community's take res- 
ponsibility for protecting their wildife resources. This involves identifying valuable wildife habitats and developing planning strategies to preserve and protect these habitats. Wildlife is not an extraneous resource to be considered after all other business has been attended to, but is a vital component of the community, whos stability directly influences the health, safety, and welfare of all citizens. 


\section{Endnotes}

1. Daniel L. Leedy, Robert M. Maestro, and Thomas M. Franklin, Planning for Wild ife in cities and Suburbs, Urban Wildlife Research Center, Inc., Ellicott City, MD, 1978, pp.29-32.

2. Department of the Environment, Sinews for Survival, London:HMSO, British governments submission to the: United Nations Conference on the Human Environment, Stockholm, 1972

3. O.H. Frankel, and M.E. Soule, Conservation and Evolution, Cambridge University Press, Cambridge, 1981 , p.36.

4. I.A. Franklin, Evolutionary change in small populations, In:Conservation Biology: An Evolutionary-Ecological Perspective, Eds. M.E. Soule and B.A. Wilcox, Sinauer Associates, Sunderland,Mass., 1980 , pp.135-150.

5. Frankel and Soule, p.104.

6. Ibid, p.101.

7. F.W. Preston, The canonical distribution of commoness and rarity, Ecology, 1962, Part l (43) pp.185-215, Part 2 (43) pp.410-432.

8. Paul Ehrlich, and Anne Ehrlich,Extinction: The Causes and Consequences of the Disappearance of Species, Random House, New York, 1981, p.46.

9. Philip Barske, The growing importance of privately owned woodlands to wildlife habitat, In: Transactions of The Northeast Fish and Wildlife Conference of 1972, Ellenville, New York, 1973, p.14l.

10. H.H. Iltis, P. Andrews, and O. Loucks, Criteria for an optimum human environment, Bulletin of Atomic Scientists, 1970,26 (1) pp.2-6. 
11. G.G. Gray, J.S. Larson, and D.A. Braunhardt, Urban conservation leadership and the wildlife resource, Urban Ecology, 1979, 4(1) pp.1-9.

12. Ervin B. Zube, Robert O. Brush, and Julius G. Pabos, Landscape Assessment: Values, Perceptions, and Resources, Dowden, Butchinson, and Ross Inc., Stroudsberg, 1975, p.47.

13. Ehrlich and Ehrlich, p.48.

14. Lewis Regenstein, The Politics of Extinction: the Shocking Story of the World's Endangered Wildlife, MacMillan Publishing Co. Inc., 1975, p.132.

15. Raymond F. Dasmond, Wildlife Biology, 2nd ed., John Wiley and Sons, New York, 1981, p.184.

16. Ibid, p.184.

17. Ruben L. Parson, Conserving American Resources, 3rd ed., Prentice-hall Inc., Englewood Cliffs, 1972 , p.432.

18. Aldo Leopold, Sand County Almanac, Oxford University Press, New York, 1949, p.204.

19. Stewart L. Udal 1, The Quiet Crisis, Bolt, Rinehart, and Winst on, New York, 1963, p.165.

20. John E. Humke, Barry S. Tindal1, Robert E. Jenkins, Bardy L. Wieting Jr., and Margaret S. Lukowski, The Preservation of Natural Diversity a Survey and Recommendations, The Nature Conservancy, 2nd ed., 1975, p.32.

21. 0.S. Department of Interior, Fish and wildlife Service, Selected List of Federal Laws and Treaties Relating to spert Fish and Wildlife, 0.S. Government Printing Office, Washington, 1979, pp.1-23.

22. Commitee on Agriculatural Land Use and Wildlife Resources, Land Use and Wildlife Resources, National Academy of Sciences, Washington, 1970, p.226.

23. Fish and Wildlife Conservation Act of 1980, Public Law 96-366-Sept.29,1980, 94 STAT.1323 16USC 2982

24. Commitee, p.226.

25. Commitee, p.228

26. Orleans Builders and Developers v. Byrne, 186 N.J.Super.432, p.433. 
27. Ibid, p.439.

28. Ibid, p.433.

29. Sarasota County v. Barg, Pla., 302 So.2d. 737, p.737.

30. H.P. Brokaw(Ed.), Hildlife and America, Council on Environmental Quality, U.S. Government Printing Office, Washington, 1978 , p.5.

31. Town of Jackson, Town of Jackson Development Code, Jackson, Wyoming, 1983

32. Moviematic Ind. v. Bd. of County Commissioners, Fla.; App., 349 So.2d. 667, p.667.

33. Ibid, p.667.

34. Horizon Adirondack Corp. V. State of N.Y. (388 NYS2d. 235); Albano $\nabla$. Washingt on (194 N.J.., Sup. 265); steel Hill Dev. Inc. v. Town of Sanbornton, et al. (469 F2d. 956).

35. Bob Grahm v. Estuary Properties, Inc., 399 So.2d. 1374

36. Moviematic, p.667.

37. Leedy, p.30.

38. Gray, p.1.

39. Jack Ward Thomas(Ed.), Wildlife Habitats in Managed Forests: The Blue Mountains of Oregon and Washington, Agriculatural Bandbook No. 553, U.S. Department of Agriculture, Forest Service, Wildlife Management Institute, Washington, 1979, p.53.

40. Ibid, p.59.

41. Ibid, p.51.

42. Ibid, p.53.

43. Ibid, p.58.

44. Lewis M. Cowardin, Virginia Carter, Francis C. Golet, and Edward T. La Roe, Classification of Wetlands and Deepwater Habitats of the United States, Office of Biological Services, Fish and Wildlife Service, U.S. Government Printing office, Washington, 1979, p.ll.

45. Ibid, p.ll. 
46. Joseph DeChiara, and Lee E. Koppelman, Time-sayer Standards for Site Planning, McGraw-Bill, New York, 1984, p. 179.

47. Thomas, p.122.

48. Ibid, P.122.

49. Ibid, p.122.

50. Larry D. Harris, The Fragmented Eorest: Island Biogeography and the Preservation of Biotic Diversity, University of Chicago Press, Chicago, 1984, P.149.

51. F.O. Sargent, and J.H. Brande, Classifying and evaluating unique natural areas for planning purposes, Journal of Soil and Water Conservation, 1976, 31(3) pp.113-116.

52. Ibid, pp.113-116.

53. Lawrence Susskind, and Scott McCreary, Techniques for resolving coastal resource management disputes through negotiation, Journal of the American Planning Association, 1985, 51(3) pp.365-374.

54. Ralph W. Tiner Jr.. Wetlands of the United States: current Status and Recent Trends, U.S. Fish and Wildlife Service, U.S. Government Printing Office, washington, 1984

55. Thomas, p.53.

56. Harris, P.142.

57. Ibid, P.142.

58. Ibid, p.143.

59. A.S. Harestad, and F.L. Bunnel, Home range and body weight - a re-evaluation, Ecolegy, 1979, (68) pp. 389-402

60. Ibid, p.389

61. Dave Hallock, Boulder County makes room for wildlife, Planning, $1984,50(9)$ p.14.

62. Ibid, p.14.

63. DeChiara and Koppelman, p.7. 
64. Rhode Island statewide Planning Program, Methods of Eliminating Conflicts, Technical paper Number 82, Appendix, 1979, p.A-17.

65. CPAD Urban Field Center, Cooperative Extension Service, and the University of Rhode Island, Preserving Open space: Approaches for Rhode Island communities, 1978 , p.29.

66. Patrick Phillips, Nantucket,s land bank: a new direction in land conservation, Urban Land, 1985, $44(12)$ p. 34.

67. Hallock, p.13.

68. Ibid, p.13.

69. Ibid, p.13.

70. Donald V.H. Walker, and Martin E. Zeller, Promoting public/private initiatives for preservation: Colorado open lands, Urban Land, 1985, 44 (11) p.14. 
Appendix A :

Sources of Information and Assistance 
From: Daniel L. Leedy, Robert M. Maestro, and Thomas $M$. Franklin, Planning for Wildlife in Cities and Suburbs, 1978, American Society of Planning officials, $1313 \mathrm{E}$. $60 \mathrm{th}$ St.. Chicago, IL 60637

PUBLICATIONS

Conservation Directory

The National Wildlife Federation

1412 Sixteenth st. 20036

Water Quality Criteria 1972

U.S. Gov. Printing off.

Washington, DC 20402

NON-PROFIT ORGANIZATIONS

Nature Conservancy

Suite 800

1800 N. Kent st.

Arlington, VA 22209

The National Wildlife Federation

1412 Sixteenth st.

N.W. Washington, DC 20036

From: Liason Conservation Directory, Office of Endangered Species, U.S. Fish and Wildlife Service, Department of the Interior, Washington, DC 20240

U.S. FISH AND WILDLIFE ENDANGERED SPECIES COORDINATORS

Write to: Regional Director

U.S. Fish and Wildlife Service

PACIFIC REGION

Suite 1692

Lloyd 500 Building

500 NE. Multnomah st. Portland, OR 97232

(503) 231-6131

NORTH CENTRAL

Federal Building

Fort Snelling

Twin Cities, MN 55111

(612) 725-3276
U.S. Government Manual

U.S. Gov. Printing of $f$. Washington, DC 20402
National Audubon Society 950 Third Ave.

New York, NY 10022 
NORTHEAST

Suite 700

One Gateway Center

Newton Corner, MA 02158

(617) 965-5100
DENVER REGION

P.O. Box 25486

Denver Federal Center

Denver, CO 80225

(303) 234-2496

ALASRA AREA

1011 E. Tudor Road

Anchorage, AK 99503

(967) 786-3435

From: Charles Thurow, William Toner, and Duncan Erley, Performance Controls for Sensitive Lands: A Practical Guide for Local Administrators, 1975, American Society of Planning Officials, 1313 East Sixtieth St., Chicago, IL 60637

U.S. FOREST SERVICE REGIONAL OFFICES

EASTERN (CT, DE, IA, IL, IN,

$M A, M R, M E, M I, M N, M O, N B$,

$N J, N Y, O B, P A, R I, V T, W I, W V)$

Clark Building

633 พ. Wisconsin Ave.

Milwaudee, WI 53203

(414) 224-3600

ROCKY MOUNTAIN

$(\mathrm{CO}, \mathrm{KS}, \mathrm{NB}, \mathrm{SD}, \mathrm{WY})$

Federal Center Bldg. 85

Denver, CO 80225

(303) 234-3711

SOUTHWESTERN (AZ, NM)

New Federal Bldg.

517 Gold Ave., S.W.

Albuquerque, NM 87101

(505) 843-2401

INTERMOU NTAIN (ID, NV, UT, WY)

Federal office Bldg.

25 th st.

Ogden, UT 84401

(801) 399-6201
SOU THERN ( AL , AR, FL , GA, RY, LA

$M A, O R, N C, S C, T N, T X, V A)$

Suite $\mathbf{8 0 0}$

1720 Peachtree Rd., N.W.

Atlanta, GA 30309

(404) 526-5177

PACIFIC (OR, WA)

319 S.W. Pine St.

Box 3623

Portland, OR 97208

(503) 226-2101

CAL IFORNIA (CA)

630 Sansome St.

San Francisco, CA 94111

(415) 556-4310

ALASRA (AR)

Federal of ice Bldg.

Box 1628

Juneau, AR 99801

(907) 586-7263

U.S. SOIL CONSERVATION SERVICE STATE OFFICES

ALABAMA

Soil Conservation Bldg.

P.O. Box 311

Audurn, AL 36830

(205) 887-7051
ALASRA

204 E. Fifth Ave.

Anchorage, AR 99501

(967) 277-3064 
ARIZONA

230 N. lst Ave.

Federal Bldg.

Phoenix, AZ 85025

(602) 261-3271

CAL I FORNIA

P.O. BOX 1819

Davis, CA 95616

(916) 678-4411

CONNECTICUT

Mansfield Professional Bldg. Storrs, CT $\$ 6268$

(203) 429-9361

FLORIDA

Federal Bldg.

P.0. Box 1208

Gainesville, FL 32601

(904) 376-3277

\section{BAWA I I \\ Room 440 \\ Alexander Young Bldg. \\ Bonolulu, BI 96813 \\ (868) 546-5792 \\ ILLINOIS \\ Federal Bldg. \\ 1200 W. Church st. \\ Champaign, IL 61820 \\ (217) 356-3785 \\ IOWA \\ 823 Federal Bldg. \\ 210 Walnut $s t$. \\ Des Moines, IA 50309 \\ (515) 284-4260}

RENTUCRY

333 Waller Ave.

Lexington, RY 40504

(606) 252-3212

MAINE

USDA BIdg.

University of Maine

Orono, ME 04473

(207) 866-2132
ARRANSAS

Federal Office Bldg.

700 West Capitol

Room 5401

Little Rock, AR 72201

(501) 372-4361

COLORADO

2490 W. 26th Ave.

Denver, CO 80211

(303) 837-4275

DELAWARE

9 East Loockerman st. Dover, DE 19901

(302) 678-0750

GEORGIA

P.O. BOX 832

Athens, GA 30601

(404) 546-2275

IDAHO

304 N. 8TH st.

P.O. Box 38

Boise, ID 83702

(208) 342-2601

INDIANA

5610 Crawfordsville Rd. Indianapolis, IN 46224 (317) 633-7201

KANSAS

760 S. Broadway

P.O. Box 600

Salina, RS 67401

(913) 823-9537

LOU ISIANA

3737 Government st.

P.O. Box 1630

Alexandria, LA 71301

(318) 443-7395

MARYLAND

Rm. 522

Hartwick Bldg.

4321 Hartwick Rd.

College Park, MD 20740

(202) 388-8457 
MASSACBUSETTS

27-29 Cottage st. Amherst, MA 01002

(413) 549-0650

MINNESOTA

208 Federal Bldg.

U.S. Courthouse

316 N. Robert St.

st. Paul, MN 55101

(612) 725-7675

MISSOURI

601 S. Business Loop 70

Box 459

Columbus, MO 65201

(314) 442-3141

NEBRASRA

134 S. $12 \mathrm{th}$ St.

Lincoln, NB 68508

(492) 475-3301

NEW BAMPSHIRE

Federal Bldg.

Durham, NH 3824

(603) 868-7734

NEW MEXICO

517 Gold Ave., S.W.

P.O. Box 2007

Albuquerque, NM 87103

(505) 843-2166

NORTH CAROLINA

Room 544

310 New Bern Ave.

Raleigh, NC $2760_{1}$

(919) 755-4210

OHIO

311 Old Federal Bldg.

3 rd and state sts.

Columbus, OH 43215

(614) 469-6785

\section{MICBIGAN}

$1405 S$. Barrison Rd.

East Lansing, MI $\mathbf{4 8 8 2 3}$

(517) 372-1910

MISSISSIPPI

Milner Bldg.

P.0. Box 610

Jackson, MI 39205

(601) 948-7821

MONTANA

Federal Bldg.

P.O. Box 970

Bozeman, MT 59715

(406) 587-3322

\section{NEVADA}

Rm. 234

U.S. Post office Bldg.

P.O. Box $485 B$

Reno, NV 89505

(702) 784-5304

NEW JERSEY

1370 Hamilton st.

Somerset, NJ $\mathbf{8 8 7 3}$

(201) 846-4500

NEW YORK

Midtown Plaza

Room 400

700 E. Water st.

Syracuse, NY 13210

(315) 473-3530

NORTH DAROTA

Federal Bldg.

P.O. Box 1458

Bismarck, ND 58501

(701) 255-4011

ORLAHOMA

Agricultural Center Bldg. Farm and Admiral Rd. Stillwater, OR 74074 (405) 372-7111 
OREGON

Washington Bldg.

1218 S.W. Washington st.

Portland, OR 97285

(503) 226-1831

PUERTO RICO

G.P.O. BOX 4868

San Juan, PR 60936

(809) 725-8966

SOUTH CAROLINA

Federal Bldg.

901 sumter st.

Columbia, sC 29201

(803) 253-8371

TENNESEE

561 U.S. Court House

Nashville, TN 37203

(615) 242-5471

UTAH

4012 Federal Bldg.

125 S. State St.

Salt Lake City, UT 84111

(801) 524-5052

\section{VIRGINIA}

Federal Bldg.

400 N. 8th St.,

P.O. Box 10026

Richmond, VA 23240

(703) 782-2455

WEST VIRGINIA

209 Prairie Ave.

P.O. Box 865

Morgantown, WV 26505

(304) 599-3441
PENNSYLVANIA

Federal Bldg.

Harrisburg, PA 17108

(717) 782-2297

RHODE ISLAND

Post office Bldg.

East Greenwich, RI $\$ 2818$

(401) 884-9499

SOUTH DAROTA

239 Wisconsin Ave., S.W.

P.O. Box 1357

Buron, SD 57350

(605) 352-8333

TEXAS

P.0. Box 648

Temple, TX 76501

(817) 773-5261

VERMONT

96 College st.

Burlington, VT 05401

(882) 862-6261

WASH INGTON

360 U.S. Court House

w. 920 Riverside Ave.

Spokane, WA 99201

(569) 456-3711

WISCONSIN

4601 Hammersley Rd.

P.O. Box 4248

Madison, WI 53711

(608) 256-4441

WYOMING

Tip Top Bldg.

345 E. 2nd St.

P.O. Box 2440

Casper, WY 82601

(307) 265-3201

U.S. GEOLOGICAL SURVEY REGIONAL PUBLIC INQUIRES OFFICES

108 Skyline Building

508 Second Avenue

Anchorage, AR 99501
7638 North Los Angeles St. Los Angeles, CA 90012 
504 Custom House

555 Battery St.

San Fransisco, CA 94111

General Services Building

18 th and F. Streets, N.W.

washington, DC 20244

8102 Federal Building

125 South State St.

Salt Lake City, UT 84111
1012 Federal Building 1961 Stout St. Denver, CO 80262

1045 Federal Building

1100 Commerce st.

Dallas, TX 75202

National Center

Room 1C-402

Reston, VA 22092

678 U.S. Court House

West 920 Riverside Ave.

Spokane, WA 99201

STATE GEOLOGICAL SURVEYS (U.S.G.S. MAPS)

ALABAMA

Geological Survey of Alabama

P.O. Drawer 0 .

University, AL 35486

ARIZONA

Arizona Bureau of Mines

University of Arizona

Tucson, AZ 85721

CAL I FORNIA

Division of Mines and Geology

Dept. of Conservation

1416 Ninth St., Room 1341

Sacramento, CA 98514

CONNECTICUT

Natural Resources Center

Dept. of Env. Protection

State office Bldg., Room 561

165 Capitol Ave.

Hartford, СT

FLORIDA

Bureau of Geology

963 West Tennessee St.

Tallahassee, FL 32304

BAWAI I

Div. of Water and Land Dev. P.O. Box 373

Bonolulu, HI 96809
ALASRA

Geological Surveys

3001 Porcupine Dr.

Anchorage, AR 99501

ARKANSAS

Ardansas Geological Comm. Vardelle Parham Geol. Ctr. 3815 West Roosevelt Rd. Little Rock, AR 72204

COLORADO

Colorado Geological Survey 1845 Sherman St.

Room 254

Denver, Co 86203

DELAWARE

Delaware Geological Survey Oniversity of Delaware Newark, DE 19711

GEORGIA

Earth and Water Division Georgia Dept. of Nat. Res. 19 Bunter St., S.W. Room 400

Atlanta, GA 30334

IDAHO

Idaho Bureau of Mines and Geology

Moscow, ID 83843 
ILLINOIS

Illinois state Geol. Survey 121 Natural Resources Bldg. Orbana, IL 61801

IOWA

Iowa Geological Survey

16 West Jefferson St.

Iowa City, IA 52240

RENTUCKY

Rentucky Geological Survey

307 Mineral Industries Bldg.

University of Rentucky

Lexington, $\mathrm{KY} \quad \mathbf{4 0 5 0 6}$

MAINE

Bureau of Geology

State Capitol

Augusta, ME $\$ 4330$

MASSACHUSETTS

Dept. of Public Works

99 Worcester st.

Wellesley Bills, MA 02181

MINNESOTA

Minnesota Geological Survey

1633 Eustis St.

St. Paul, MN 55108

MISSOURI

Missouri Geol. Survey

and Water Resources

P.O. Box 250

Rolla, MO 65401

NEB RASRA

Conservation and Survey Div. University of Nebraska

Lincoln, NE 68588
INDIANA

Indiana Geological Survey

Dept. of Natural Resources 611 North Walnut Grove Bloomington, IN 47481

\section{RANSAS}

Ransas Geological Survey

Raymond C. Moore Ball

1936 Avenue A. Campus West

University of Ransas

Lawrence, RS 66044

LOU ISI ANA

Louisisana Geol. Survey

Box G

Oniversity station

Baton Rouge, LA 70803

MARYLAND

Maryland Geol. Survey

214 Lat robe Ball

Johns Hopkins University

Baltimore, MD 21218

MICBIGAN

Geological Survey Div.

Michigan Dept. of Natural

Resources

Stevens T. Mason Bldg.

Lansing, MI 48926

MISSISSI PPI

Mississippi Geol. Survey

2525 North West st.

P.O. Box 4915

Jackson, MS 39216

MONTANA

Montana Bureau of Mines and Geology

Montana College of Mineral

Science and Technology

Butte, MT 59701

NEVADA

Nevada Bureau of Mines

and Geology

University of Nevada

Reno, NV 89507 
NEW BAMPSHIRE

Dept. of Res. and Econ. Dev. Office of State Geologist

James Hall

Oniversity of New Bampshire

Durham, NH 3824

NEW MEXICO

New Mexico Bureau of Mines

and Mineral Resources

Campus station

Socorro, NM 87801

NORTH CAROL INA

Office of Earth Resources

Dept. of Nat. and Econ. Res. P.O. Box 27687

Raleigh, NC 27611

OHIO

Div. of Geological Survey

Ohio Dept. of Nat. Res.

Fountain Square

Columbus, OH 43224

OREGON

State Department of Geology

and Mineral Industries

1069 State office Bldg.

1400 S.W. Fifth Ave.

Portland, OR 97201

PUERTO RICO

Programa De Geologiz

Deptamento De Recursos

Naturales

Apt. 5887

Puerta de Tierra

San Juan, PR 00906

SOUTH DAKOTA

State Geological Survey

Science Center

University of South Dakota

Vermillion, SD 57069
NEW JERSEY

Bureau of Geology and

Topography

P.O. Box 2809

Trenton, NJ $\$ 8625$

NEW YORKRA

State Museum and Science

Service

Geological Survey

State Education Bldg.

Room 973

Albany, NY 12224

NORTH DAROTA

North Dakota Geol. Survey University Station

Grand Forks, ND 58201

OKLAHOMA

Oklahoma Geological Survey

University of Oklahoma

830 Van vleet Oval

Room 163

Norman, OR 73069

PENNSYLVANIA

Bureau of Topographic and Geologic Survey

Dept. of Env. Resources

660 Boas st.

Harrisburg, PA 17120

SOUTH CAROLINA

Division of Geology

State Development Board

P.O. Box 927

Columbia, SC 57069

TENNESSEE

Dept. of Conservation

Division of Geology

G-5 state office BIdg.

Nashville, TN 37219 
TEXAS

Bureau of Economic Geology

University of Texas

University station, Box $x$

Austin, TX 78712

VERMONT

Vermont Gological Survey

Room 211, Perkins Ball

University of Vermont

Burlington, VT $\$ 5401$

WASH INGTON

Div. of Geol. and Earth Res.

Dept. of Natural Resources

Olympia, WA 98504

WISCONSIN

Wisconsin Geological and

Natural Bistory Survey

University of Wisconsin Ext. 1815 University Ave.

Madison, WI 53706
UTAB

Utah Geological and

Mineralogical Survey

163 Utah Geol. Surv. Bldg. University of otah

Salt Lake City, UT $\mathbf{8 4 1 1 2}$

VIRGINIA

Virginia Div. of Min. Res. P.O. Box 3667

Charlottesville, VA 22903

WEST VIRGINIA

West Virginia Geologic

and Economic Survey

P.O. Box 879

Morgantown, WV 26505

WYOMING

Geol. Survey of Wyoming

P.O. Box 3808

University station

University of Wyoming

Laramie, WY 82071

From: Zev Naveh, and Arthur S. Lieberman, Landscape Ecology:Theory and Application, 1984, Springer-Verlag, New York, 356 pp.

STATE-LEVEL NATURAL RESOURCE INFORMATION SYSTEM LOCATIONS

State and system Name

ALABAMA RESOURCE

INFORMATION SYSTEM

(ARIS)

ALASRA

ARIZONA RESOURCE

INFORMATION SYSTEM

(ARIS)
Address

Office of state Planning and Federal Programs

3734 Atlantic Bighway

Montgomery, AL 36130

Department of Natural Res. 323 E. 4th Ave.

Anchorage, AR 99501

State Land Department

Information Services Div. 1624 West Adams, Room 300 Phoenix. AZ 85007 


\author{
ARRANSAS RESOURCE \\ MANAGEMENT INPORHATION \\ SYSTEM (ARHIS) \\ CAL IFORNIA ENVIRONMENTAL \\ DATA CENTER
}

COLORADO

CONNECTICUT NATURAL

RESOURCES CENTER

FLORIDA GENERAL ENVIRONMENTAL DATA

GEORGIA RESOURCE

ASSESSMENT PROGRAM

IOWA WATER RESOURCES

DATA SYSTEM(IWARDS)

RENTUCKY RESOURCE

INPORMATION SYSTEM

(RRIS)

LOUISIANA AREAL RESOURCE

INFORMATION SYSTEM (LARIA)

MAINE

MARYLAND AUTOMATED

GEOGRAPHIC INFORMATION

SYSTEM (MAGI)
Department of Economic Development

$\$ 1$ Capitol Mall

Little Rock, AR 72201

Office of Planning and Research

Governor's office

1440 Tenth Street

Sacramento, CA 95814

Dept. of Local Affairs 520 State Centennial BIdg. 1313 Sherman street

Denver, V4CO 80203

Dept. of Environ. Protect. 165 Captial Avenue

Hartford, CT $\$ 6115$

Dept. of Env. Regulation, Office of Program and

Data Analysis

2600 Blair stone Road

Tallahasee, FL 32301

Dept. of Natural Resources 270 Washington St. SW.

Room 700

Atlanta, GA 36334

Iowa Geological Survey

123 N. Capitol st.

Iowa City, IA 52242

Office of Policy and

Analysis

Capitol Plaza Tower

Frankfort, $K Y$

State Planning office

4528 Bennington Ave.

Baton Rouge, LA 70808

Maine Forest Service

255 Nutting Ball

Orono, Maine B4469

Dept. of state Planning

38I w. Preston St.

Baltimore, MD 21201 
MINNESOTA LAND MANAGEMENT

INPORMATION SYSTEM (MIMIS)

MISSISSIPPI AUTOMATED

RESOURCE INPORMATION

SYSTEM (MARIS)

MISSOURI GEOGRAPHIC

RESOURCE CENTER

MONTANA GEO-DATA

INPORMATION SYSTEM

NEBRASRA NATURAL RESOURCES

INPORMATION SYSTEM

(NATURAL RESOURCES DATA BANR)

NEI JERSEY

NEN YORR LAND USE AND

NATURAL RESOURCE

INPORMATION SYSTEM

NORTH CAROLINA LAND

RESOURCES INFORMATION

SERV ICE (LRIS)

NORTH DAKOTA REGIONAL

ENVIRONMENTAL ASSESSMENT

PROGRAM (REAP)

OHIO CAPABILITY ANALYSIS

PROJECT (OCAP)

ORLAHOMA GRAPHICS

DATA SYSTEM
Land Management Information Center

550 Cedar st.

st. Paul, MN 55101

Mississippi Research and Development Center

P.O. Box 2470

Jackson, MI 39205

University of Missouri

240 Electrical Engineering Building

Columbia, MO 65211

Dept. of Community Affairs Research and Info. Systems Capitol Station

Belena, MT 59601

Natural Resources Comm. 301 Centennial Mall South P.O. Box 94876

Lincoln, NB 68509

Div. of state and Regional Planning, Bureau of Planning and Automated Systems

88 E. State street. Trenton, NJ $\$ 8625$

Resource Info. Lab. Box 22

Roberts Ball

Ithaca, NY 14853

Dept. of Natural Resources and Community Development Box 27687

Raleigh, NC 27611

Legislative Council State Capitol

Bismarck, ND 58505

Dept. of Natural Resources Division of Water Fountain Square, Bldg. E. Columbus, OH 43224

Oklahoma Foundation for Research and Development utilization 


\begin{tabular}{|c|c|}
\hline & $\begin{array}{l}\text { P.O. Box } 1328 \\
\text { Edmond, OR } 73034\end{array}$ \\
\hline $\begin{array}{l}\text { PENNSYLVANIA LAND USE } \\
\text { DATA ANALYSIS (LUDA) }\end{array}$ & $\begin{array}{l}\text { Dept. of Environmental } \\
\text { Resources, Bureau of } \\
\text { Environmental Planning } \\
\text { lol S. 2nd St. } \\
\text { Harrisburg, PA } 17120\end{array}$ \\
\hline SOUTH CAROLINA & $\begin{array}{l}\text { Univ. of South Carolina } \\
\text { Computer Services Div. } \\
\text { Columbia, SC } 29208\end{array}$ \\
\hline $\begin{array}{l}\text { SOUTH DAROTA RESOURCE } \\
\text { INPORMATION SYSTEM }\end{array}$ & $\begin{array}{l}\text { State Planning Bureau } \\
\text { Planning Info. Section } \\
415 \text { S. Chapelie } \\
\text { Pierre, SD } 57501\end{array}$ \\
\hline $\begin{array}{l}\text { TENNESSEE AREAL DESIGN } \\
\text { AND PLANNING TOOL (ADAPT) }\end{array}$ & $\begin{array}{l}\text { Tennessee Dept. of Public } \\
\text { Health, Div. of Water } \\
\text { Quality Control } \\
621 \text { Capitol Bill Building } \\
\text { Nashville, TN }\end{array}$ \\
\hline $\begin{array}{l}\text { TEXAS NATURAL RESOURCES } \\
\text { INPORMATION(TNRIS) }\end{array}$ & $\begin{array}{l}\text { Dept. of Water Resources } \\
\text { P.O. Box } 13687 \\
\text { Austin, Texas } 78711\end{array}$ \\
\hline $\begin{array}{l}\text { VIRGINIA RESOURCES } \\
\text { INPORMATION SYSTEM } \\
\text { (VARIS) }\end{array}$ & $\begin{array}{l}\text { Office of Commerce and } \\
\text { Resources } \\
\text { Richmond, VA } 23219\end{array}$ \\
\hline $\begin{array}{l}\text { WASH INGTON GRIDDED RESOURCE } \\
\text { INVENTORY DATA SYSTEH(GRIDS) }\end{array}$ & $\begin{array}{l}\text { Department of Natural } \\
\text { Resources }\end{array}$ \\
\hline
\end{tabular}


Appendix B :

Regional Listing of Selected Plants Ranked According to Their Value for Wildlife 
From: Daniel L. Leedy, Robert M. Maestro, and Thomas M. Franklin, Planning for Wildlife in Cities and Suburbs, 1978, American Society of Planning Officials, 1313 E. 60th St., Chicago, IL 68637

REGIONAL LISTING OF SELECTED PLANTS

RANRED ACCORDING TO TEEIR VALUE FOR WILDLIFE

NORTHEAST REGION

Woody

Plants
Upl and Weeds and Berbs
Marsh and Aquatic Plants Plants

$\begin{array}{ll}\text { Oak } & \text { Ragweed } \\ \text { Blackberry } & \text { Bristle grass } \\ \text { Hild cherry } & \text { Sedge } \\ \text { Pine } & \text { Crabgrass } \\ \text { Dogwood } & \text { Panic grass } \\ \text { Grape } & \text { Pigweed } \\ \text { Maple } & \text { Clover } \\ \text { Beech } & \text { Sheep sorrel } \\ \text { Blueberry } & \text { Goosefoot } \\ \text { Birch } & \text { Dropseed grass } \\ \text { Sumac } & \text { Bluegrass } \\ \text { Aspen } & \text { Pokeweed } \\ \text { Spruce } & \text { Dandelion } \\ \text { Bickory } & \text { Plantain }\end{array}$

Fir

Alder

Poison ivy

Black gum

Smartweed

Pondweed

wild rice

Bulrush

Wild celery

Naiad

Cord grass

widgeon grass

Cut-grass

Spike rush

Eelgrass

Bur reed

Wild millet

Duckweed

Algae

Ar rowhead

Muskgrass

Mulberry

Arrow arum

Corn

Wheat

Oats

Apple

Cherry

Timothy

Barley

Elm

Cedar

Serviceberry

Hazelnut

Willow

Heml ock

Greenbrier

Ash

Elderber ry

Virginia creeper

Tulop tree

Mountain ash

Bolly

Bawthorn

Black walnut 
PACIFIC REGION

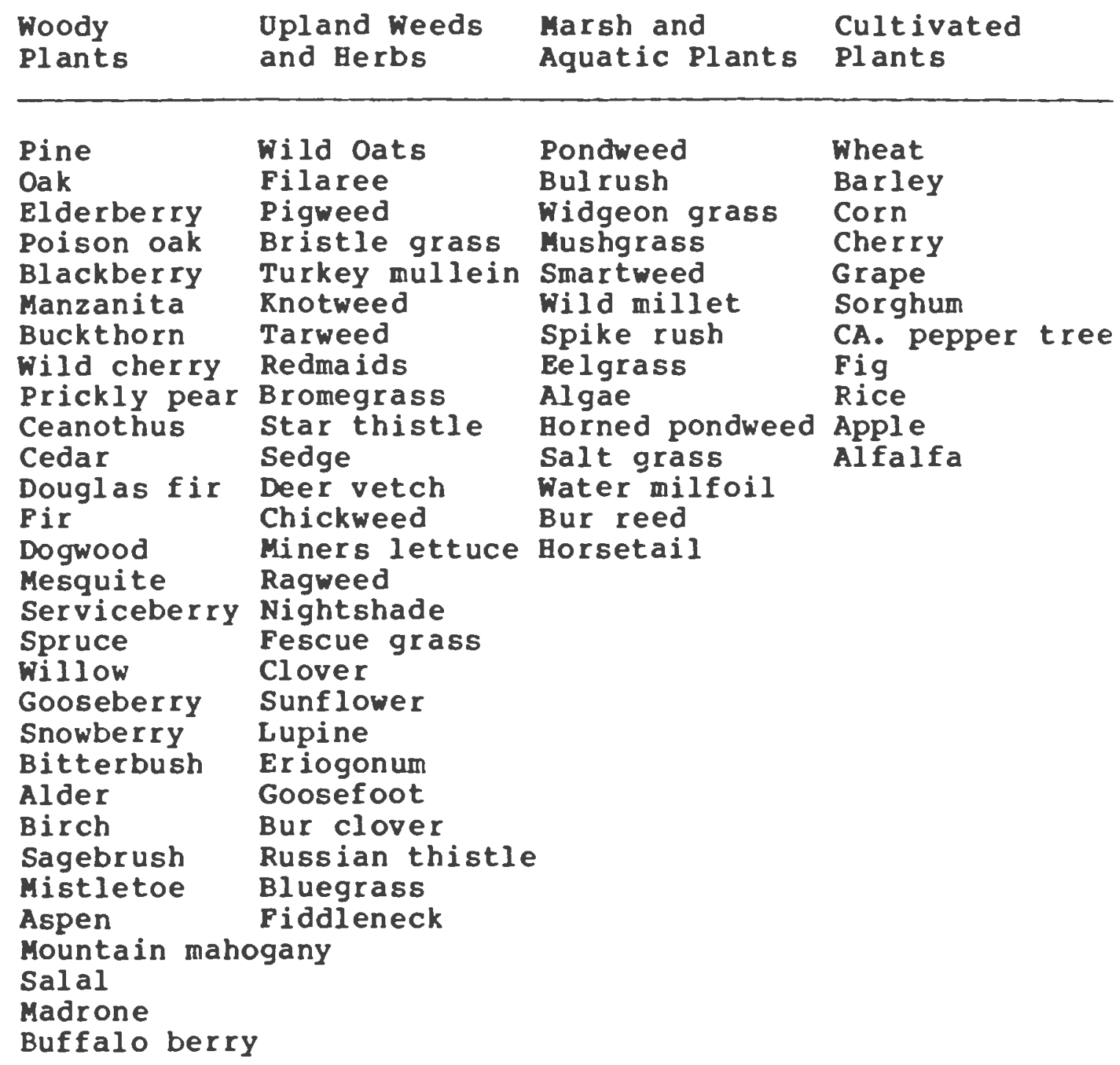


PRAIRIE REGION

\begin{tabular}{|c|c|c|c|}
\hline $\begin{array}{l}\text { Wood } \\
\text { Plants }\end{array}$ & $\begin{array}{l}\text { Upland Weeds } \\
\text { and Herbs }\end{array}$ & $\begin{array}{l}\text { Marsh and } \\
\text { Aquatic Plants }\end{array}$ & $\begin{array}{l}\text { Cultivated } \\
\text { Plants }\end{array}$ \\
\hline $\begin{array}{l}\text { Oak } \\
\text { Hackberry } \\
\text { Prickly pear } \\
\text { Wild rose } \\
\text { Wild cherry } \\
\text { Cedar } \\
\text { Grape } \\
\text { Sagebrush } \\
\text { Snowberry } \\
\text { Sumac } \\
\text { Poison ivy } \\
\text { Persimmon } \\
\text { Mulberry } \\
\text { Dogwood } \\
\text { Serviceberry } \\
\text { Saltbush } \\
\text { Holly } \\
\text { Blackberry } \\
\text { Pine } \\
\text { Mesquite } \\
\text { Alder } \\
\text { Barberry } \\
\text { Bearberry } \\
\text { Virginia cree } \\
\text { Rabbit brush }\end{array}$ & $\begin{array}{l}\text { Bristle grass } \\
\text { Ragweed } \\
\text { Sunflower } \\
\text { Panic grass } \\
\text { Rnotweed } \\
\text { Pigweed } \\
\text { Doveweed } \\
\text { Goosefoot } \\
\text { Russian this. } \\
\text { Crabgrass } \\
\text { Dropseed gr. } \\
\text { Clover } \\
\text { Needle grass } \\
\text { Sedge } \\
\text { Fescue grass } \\
\text { Grama grass }\end{array}$ & $\begin{array}{l}\text { Pondweed } \\
\text { Bulrush } \\
\text { Widgeon grass } \\
\text { Muskgrass } \\
\text { Smartweed } \\
\text { Wild millet } \\
\text { Spike rush } \\
\text { Algae } \\
\text { Bur reed } \\
\text { Horestail } \\
\text { Borned pondweed } \\
\text { Water milfoil } \\
\text { Cattail }\end{array}$ & $\begin{array}{l}\text { Corn } \\
\text { Wheat } \\
\text { Oats } \\
\text { Sorghum } \\
\text { Apple } \\
\text { Alfalfa } \\
\text { Barley }\end{array}$ \\
\hline
\end{tabular}




\section{SOUTHEAST REGION}

\begin{tabular}{|c|c|c|c|}
\hline $\begin{array}{l}\text { Woody } \\
\text { Plants }\end{array}$ & $\begin{array}{l}\text { Upland Weeds } \\
\text { and Herbs }\end{array}$ & $\begin{array}{l}\text { Marsh and } \\
\text { Aquatic Plants }\end{array}$ & $\begin{array}{l}\text { Cultivated } \\
\text { Plants }\end{array}$ \\
\hline $\begin{array}{l}\text { Oak } \\
\text { Pine } \\
\text { Blackberry } \\
\text { Wild cherry } \\
\text { Greenbrier } \\
\text { Grape } \\
\text { Blueberry } \\
\text { Hickory } \\
\text { Black gum } \\
\text { Holly } \\
\text { Poison ivy } \\
\text { Beech } \\
\text { Maple } \\
\text { Virginia cree } \\
\text { Persimmon } \\
\text { Wax myrtle } \\
\text { Dogwood } \\
\text { Mulberry } \\
\text { Tulip tree } \\
\text { Ash } \\
\text { Palmetto } \\
\text { Sweet gum } \\
\text { Elderberry } \\
\text { Cedar } \\
\text { Hackberry } \\
\text { Swamp ironwoo }\end{array}$ & $\begin{array}{l}\text { Panic grass } \\
\text { Bristle grass } \\
\text { Ragweed } \\
\text { Paspalum } \\
\text { Crabgrass } \\
\text { Dovewood } \\
\text { Sedge } \\
\text { Pokeweed } \\
\text { Lespediza } \\
\text { eper }\end{array}$ & $\begin{array}{l}\text { Bulrush } \\
\text { Pondweed } \\
\text { widgeon grass } \\
\text { Cord grass } \\
\text { Smartweed } \\
\text { Spike rush } \\
\text { Duckweed } \\
\text { Naiad } \\
\text { Water lily } \\
\text { Muskgrass } \\
\text { Chufa } \\
\text { Arrowhead } \\
\text { Algae } \\
\text { Wild millet } \\
\text { Cattail } \\
\text { Coontail } \\
\text { wild rice } \\
\text { Salt grass } \\
\text { wild celery }\end{array}$ & $\begin{array}{l}\text { Corn } \\
\text { Rice } \\
\text { Wheat } \\
\text { Oats } \\
\text { Apple }\end{array}$ \\
\hline
\end{tabular}


MOUNTAIN-DESERT REGION

Woody Plants
Upland weeds and Berbs
Marsh and

Aquatic Plants Plants

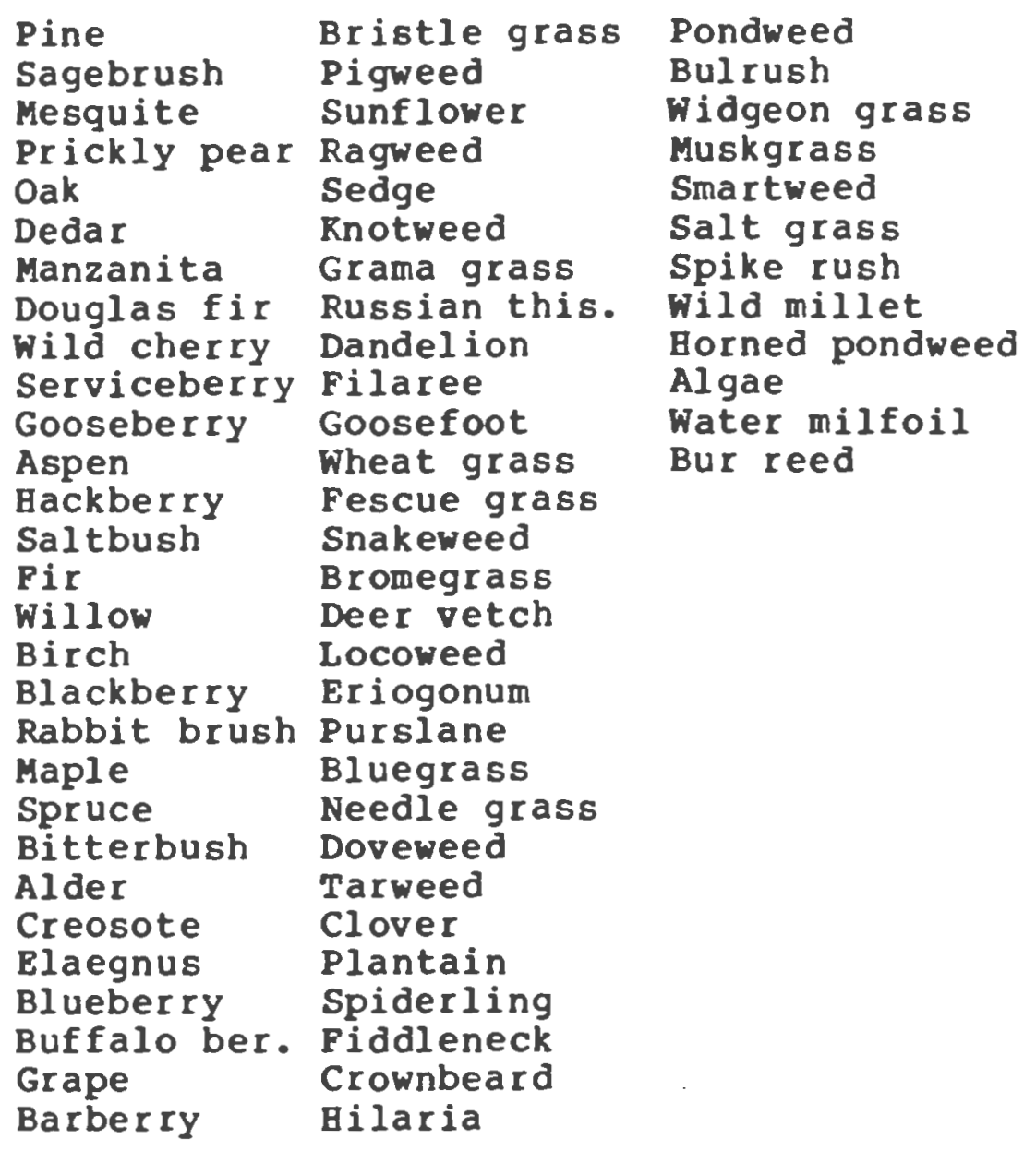

Wheat

Oats

Corn

Sorghum

Barley

Alfalfa

Cherry

Apple 

Applicable to Wildlife Conservation 
ENV IRONMEITAL IMPACT STATBMENT ORDINANCE (CHATAM, M.J.)

BE IT ORDA INED by the Township Comnittee of the Tomohip of Chatan, in the County of Morria, New Jervey, as follows:

1. Section 16.03 of the Zoning Ordinance of the Tomehip of Chatan entitle "An Ordinance to Divide the Township of Chetan into Districts or Zones ad to Regulate Thesein the Location and Bulk of Buildings and other structures and the Noture and Extent of Their Use;" adopted June 3 , 1943, as supplemented and amended, and known as the "Zoning Ordinance of the Township of Chatan," is hereby anended by adding thereto the following:

"Every developaent plan ahall be accompanied by 12 coples of an environmental impact statement which shall

1. describe all of the probable effects, both on-site and off-site, of the proposed development upon:

a. The natural resources of all kinds, including plant and vildife;

bb. hydrologic conditions and existing surface and storm ter drainage pattern;

cc. 8011 erosion and sedimentation -1 th reference to standards established by Township Ordinance 21-72;

dd. water nuality - ith reference to standards established by the Ner Jersey Department of Environmental Protection;

ee. Ir nuality -ith reference to standards established by the Ner Jeraey Department of Environmental Protection;

11. noise:

gg. potable water supply;

hh. trapflc volume and flow;

11. municipal services renulred to serve the proposed development, and

fj. health, gafety and welfare of the public;

2. discuss alternative proposals for the proposed development which will reduce or eliminate any adverse onsite or off-site environmental effects; and 
3. discuss the steps proposed to be ta'en before, during and after the development to minimize ony adverse on-gite or off-gite onvironmental effects which cannot be avoided.

"The Planning Board ohall formid 2 coples of every environmental impact stotement to the Townghip Environmental Conission, which ay furnigh comente thereon to the planning Board."

2. Section 16.04 of the Zoning Ordinance of the Tomnghip of Chatan 18 bereby amended by adding thereto the following paragraph:

"In approving a development plan, the planning Board an renuire revision or supplementation of the environmental impact stotement, may select anong alternative proposals and way establish conditions considered necessary to eliminate or ainimize any temporary or permanent adverse on-site or off-site environmental effects of the proposed development." 


\section{ENVIRONMENTAL IMPACT STATEMENT ORDINANCE (WONHOUTH BEACH, N.J.)}

\section{"514. E Environmental Impact Report}

An environmental impact report shall accompany all applications for site plan approval. Such report shall provide the information needed to evaluate the effects of the project for which site plan approval is sought upon the environment and shall include data to be distributed, reviewed and passed upon as follows:

a. A project description which shall specify what is to be done and how it is to be done, during construction and operation, as well as recital of alternative plans deemed practicable to achieve the objective.

b. An inventory of existing environmental conditions at the project site and in the surrounding region which shall describe air quality, water quality, water supply, hydrology, geology, soils and properties thereof, including capabilities and limitations, sewerage systems, topography, slope, vegetation, wildlife, habitat, aquatic organisms, noise characteristics and levels, demography, land use, aesthetics, history and archeology. Air and water quality shall be described ith reference to standards promulgated by the Department of Environmental Protection of the State of New Jersey and soils shall be described with reference to criteria contained in the Soil Conservation District Standards and Specifications.

c. An assessment of the probable impact of the project upon all topics set forth in $b$, above.

d. A listing and evaluation of adverse environmental impacts which cannot be avoided, with particular emphasis upon air or water pollution, increase in noise, damage to plant, tree and wildlife systems, damage to natural resources, displacement of people and businesses, displacement of eyisting farms, increase in sedimentation and siltation, increase in municipal services and consequences to municipal tay structure. Off-site impact shall also be set forth and evaluated. 
e. A description of steps to be taken to minimize adverse environmental impacts during construction and operation, both at the project site and in the surrounding region, such description to be accompanied by necessary maps, schedules and other e:planatory data as may be needed to clarify and $e$ plain the actions to be taken.

f. A statement concerning any irreversible and irretrievable commitment of resources which would be involved in the proposed action should it be implemented.

g. A statement of alternatives to the proposed project which might avoid some or all of the adverse environmental effects, including a no-action alternat ive.

h. Three copies of the Environmental Impact Report shall be submitted to the planning Board of the Borough of Monmouth Beach together with a filing fee of $\$ 200.00$ to cover the cost of reviewing and processing the same.

i. The Planning Board shall submit the Environmental Impact Report to the Environmental Commission of the Borough of Monmouth Beach for review and recommendation. The Environmental Commission shall review the Report and submit to the planning Board its recommendations respecting the same within 60 days after receipt thereof. Upon completion of all reviews and public hearings, but in any event not later than 30 days after the date of its next regular meeting following the filing of the Report, the planning Board shall either approve or disapprove the Environmental Impact Report as a part of its underlying function with respect to site plan review. In reaching a decision the Planning Board shall take into consideration the effect of applicant's proposed project upon all aspects of the environment as outlined above as well as the sufficiency of applicant's proposals for dealing with any immediate or projected adverse environmental effects. If the planning Board fails to act within the time period set forth above, unless e tended by agreement with the applicant, the Report shall be deemed to have been disapproved.

j. Upon approval by the Planning Board, the Environmental Impact Report shall be marked or stamped "Approved" 
by the Secretary of the Planning Board and ahell be designoted as tbe "Final Environmental Iapact Report."

k. Notrithstanding the foregolng, the planning Bonrd may, at the reouest of an applicant, wive the reaulrement for an Environeental Inpact Report if oufficient evidence is subnitted to support a conclusion that the proposed developeent -111 have alight or negligible environmental impsct. Portions of such ronuirement may 11 cerise be mived upon a Pinding that a conplete Report need not be prepared in order to evaluate adenuately the environmental inpact of a particular project.

1. An Environmental Inpact Report as reaulred herein ghall also be submitted as to all public or oussipublic projects unless such are exempt from the renulroments of local lav by supervening county, state or federal 1จ०." 
OPEN SPACE DISTRICT REgULATIONS (PALO ALTO, CALIPORNIA)

18.71.010 Purpose. The purpose and intent of this district is (a) to protect the public health, safety and velfare; (b) the protect and preserve open space land as a limited and valuable respurce; (c) to permit the reasonable use of open space land, while at the same time preserving and protecting 1 ts inherent open space characteristics to assure its continued a vallability for the following: as agricultural land, scenic land, recreation land, conservation or natural resource land; for the containment of urban sprawl and the structuring of urban development, and for the retention of land in 1 ts natural or near natural state to protect life and property in the community from hazards of fire, flood, seismic activity; and (d) to coordinate with and carry out federal, state, reglonal, county, and city open space plans. (Ord. 26 54 Art. II Section 1 (part), 1972).

18.71.020 Definitions. As used in this chapter, unless otherise apparent from the context, the following definitions shall apply:

a. "Conservation or Natural Resource," Includes, but is not necessarily limited to streams, watersheds, ground water recharge, solls, wildife habitat, as defined hereln, special land forms, natural vegetation.

c. "Open Space Land" any parcel or area of land essentially unimproved or in its natural state, and devoted to an open space use as defined herein, and which 1s designated in the Open Space Blement for an open space use.

d. "Open Space District", any area of land or water designated ' $O-S$ ' and subject to all of the terms and regulations of this chapter.

e. "Open Space Use" means the use of land for

1. Public recreation

2. Enjoyment of scenic beauty

3 . Conservation of use of natural resources

4. Production of food and fiber

5. Protection of man and his artifacts (buildings, property,etc.)

6. Contalnment and structuring of urban development

f. "Recreation land," any area of land or water susceptible to recreational uses.

g. "Scenic land," any a rea of land or mater which possess scenic qualities worthy of preservation. 
b. "Wildlife babitat," any area of land or weter valuable or necesears to the precervetion and enbacenent of vildilfe resources. (Ord. 2654 Art II, section 1 (part), 1972).

18.71.030 Regulat1ong eatablished. The folloolng apecific regulations and the general reguiatione eet fortb in Chapter 18.88 of this code shall apply in all 0-s diatricts. (Ord. 2654 Art II Sect1on I(part), 1972).

18.71.040 s1te and Design approval requ1red. All uses peratted vithin tbis district locluding those for which a use pernit is required shall be subject to approval for any developient, construction, or improvenents as provided in Chapter 18.82 of this code. (Ord. 2654 Art II Section 1 (part, 1972).

18.71.050 Use Permitted.

1. Agricultural uses:
a. animal husbandry
b. crops
c. dairglog
d. hortlculture, lncluding nurserles
e. 11 vestock farming
f. tree farming
8. viticulture and aimilar uses not inconsistent $\mathbf{1}$ th the intent and purpose of this chapter, but excluding hog laruling

2. Botanical conservatorles, outdoor nature laboratorles, and sinilar lacilities.

3. Native w11dilfe anctuaries

4. One-tan11y dve111ngs.

5. Accessory bulldings and acceoory uses.

(Ord. 2654 Art II Section1 (part), 1972).

18.71.060 Use requiriag use pernits. A use peritt shall be lirst obtalned for the following uses as provided in Chapter 18.90 of th1s code, when the applicant can establish adequate justification that the proposed use 1111 be consistent and comptible with the intent and purpose of this chapter, and that the number of employees and resident population shall approximate that which would result from a pripcipal permitted use:

1. Comounication and utility facilities

2. Educational, charitable, researcb and philanthropic institutions.

3. Guest ranches. 
4. Recreational uses including riding academies, cluba, stables country clubs, and goll courses. (Ord. 2654 Art II section 1 (part, 1972).

18.71.070 Lot Area. M1nimum lot are shall be ten (10) acres. (Ord 2654 Art II, Section 1 (part), 1972).

18.71.080 Maximun bullding coverage. The maxinum impervious area and bullding coverage, shall be 3.5 percent. (Ord 2564 Art II Section 1 (part), 1972).

18.71.090 Front Yard. Front yards shall be a minimum of thirty (30) feet. (Ord 2664 Art II Section 1(part, 1972).

18.71.100 side Yards. Side yards shall be a inimum of thirty (30) feet. (Ord 2654 Art II Section 1(part, 1972).

18.71.110 Rear Yards. Rear Yards shall be minimum of thirty (30) feet. (ord. 2654 Art II Section l(part), 1972).

18.71.120 Automoblle. Four (4) car spaces shall be required for each dwelling unit, one of which shall be covered parking. Such spaces shall not be located in any required front or side yard. (Ord. 2654 Art II Section I(part), 1972).

18.71.130 Bullding Height limit. Bulldings shall not exceed two (2) storles, or twenty-pive (25) feet. (Ord.2654 Art II Section l(part), 1972).

\subsubsection{Special Regulations.}

1. Geological Solls Investigation and Report. All Applications for site and Design Approval shall be accompanied by a combined in-depth geologic and solls lavestigation and report prepared by a registered geologist certified by the state of California as an englneering geologist, and by a licensed civil englneer qualified in soll mechanics. Such report shall be based on surface, sub-gurface, and laboratory investigations and examinations and shall fully and clearly present (a) all pertinent data, interpretations and evaluations; (b) the significance of the. data; Interpretations and evaluations with respect to the effect upon future geological processes both on and off the site; (c) recommendations for any additional investigations that shoudy be made. All costs and expenses incurred as a result of the requirements of this section, including the costs and expense on an independent review of the material submitted hereunder by qualified persons retained by the city, shall be borne by the applicant.

2. Landscaping. The existing natural vegetation and land formations shall remaln in a natural state unless notification is found to be necessary for a spectfic use allowed herein 
through the Site and Design Approval Procedure. Reduction or elinination of $f$ ire hazards will be required where heavy concentrations of flamable vegetation occurs. Lndscaping as may be necessary and required shall be consistent with the purpose of this chapter.

3. Tree Removal. Removal of 11 ve trees shall be permitted as provided in Title 8 of this code.

4. Access to Remote Areas. Roads, tracks, driveways, trails, or runvays for automobiles, trucks, buses, or motorcycles or other wheeled vehicles shall not be developed except upon the securing of site and Design Approval. No such approval ghall be granted except upon finding that the purpose for which the roads, tracks, driveways, trails. or runways are proposed 18 essential for the establisbment or maintenance of a use which 18 expressiy permitted herein and that the design and location of the proposed roads, tracks, driveways, tra118, or runways $\mathbf{1 1 1}$ be compatible vith the terrain.

The use of all roads tracks driveways trails. or runways existing at the time of the adoption of this chapter which are nonconforming or have been established wi thout proper approvals shall be terminated and shall be returned to natural terrain unless given approval in accordance with the regulations set forth in this chapter.

5. Grading No grading for which a grading permit is required shall be authorized except upon the securing of site and Design Approval. No such approval shall be granted except upon a finding that the purpose for which the grading is proposed is essential for the establishment or maintenance of a use which 18 expressig permitted herein and that the design, scope, and location of the grading proposed will be compatible with adjacent areas and will result in the least disturbance of the terrain and the natural land features. All grading for which no permits or approvals are required shall be subject to the provistons set forth in this chapter.

6 Soil Erosion and Land Management. No site and design plan shall be approved unless $1 t$ includes soil erosion and sediment control measures in accordance with any adopted procedures technical standards and specifications of the planning Commission. No approval 1 ill be granted unless all needed erosion control measures bave been completed or substantially provided for in accordance with said standards and specifications. The applicant shall bear the fibal responsibility for the installation and construction of all required erosion control measures according to the provisions of said standards and specifications.

7. Subdivision. All divisions of land into four (4) or more parcels shall be designedc on the cluster principle and 
minimize roads; to minimize cut, fill, and grading operations; to locate development in less rather than more conspicuous areas; and to achieve the purpose of this chapter.

8. Substandard Lots. Any parcel of land not meeting the area or dimension irequirements of this chapter shall be deemed a lawful bullding site if such parcel was a lawful building site on the effective date of this chapter. All other requirements of this chapter shall apply to any such parcel. (ord 2654 Art II Section l(part), 1972). 
MODEL TLOODPLAIN AND WETLANDS PROTECTION ORDINANCE (OAKLAND COUNTY, MICHIGAN)

An ordinance to protect the watercourses, floodplains and wetlands on Township, Oakland County, Michigan; to regulate the use of land areas subject to periodic flooding; to protect economic property values, aesthetic and recreational values, and other natural resource values associated with the floodplains and wetlands of this township to provide for permits for the use of these resource areas; and to provide for penalties for violations of this ordinance adopted to secure the public health, safety, and general welfare under the combined authority of Act 246 of the Public Acts of 1945, as amended, and Act 184 of the Public Acts of 1943, as amended.

The Township Board of the Township of Oakland, State of Michigan, ORDAINS:

, County of

ARTICLE I - SHORT TITLE

This ordinance shall be known and may be cited as the Ordinance. Township Floodplain and Wetlands Protection

ARTICLE II - PURPOSE

SECTION 1. Consistent with the letter and spirit of Act 246 of the Public Acts of 1945, the Township Board of Township finds that rapid growth, the spread of development, and increasing demands upon natural resources have had the effect of encroaching upon, despoiling, polluting or eliminating many of its watercourses and wetlands, and other natural resources and processes associated therewith which, if preserved and maintained in an undisturbed and natural condition, constitute important physical, aesthetic, recreation and economic assets to existing and future residents of the Township.

SECTION 2. Therefore, the purposes of this ordinance are:

A. To provide for the protection, preservation, proper maintenance, and use of Township watercourses and wetlands in oder to minimize disturbance to them and to prevent damage from erosion, turbidity or siltation, a loss of wildife and vegetation, and/or from the destruction of the natural habitat thereof;

B. To provide for the protection of the Township's potable fresh water supplies from the dangers of drought, 
overdraft, pollution, or mismanagement;

C, To secure safety from floods; to reduce the financial burden imposed upon the community thoough rescue and relief efforts occasioned by the occupancy or use of areas subject to periodic flooding; to prevent loss of life, property damage and other losses and risks associated with flood conditions; to preserve the 10cation, character and extend of natural drainage courses.

\section{ART ICLE VI - WATERCOURSE AND WETLANDS PROTECTION}

SECTION 1. Prohibited Acts. Except as hereinafter provided in this article, it shall be unlawful for any person without obtaining a witten permit therefore from

the Township Board to:

A. Deposit or permit to be deposited any material, including structures, into, within or upon any watercourse or wetland area, or within 25 feet of the edge of any watercourse, designated on the officlal Maps of the Oakland planning Commission.

B. Remove or permit to be removed any material from any watercourse or wetland area, or from any area within 25 feet of any watercourse, designated on the official Maps of the Oakland County Planning Commission.

SECTION 2. Permitted Acts.

A. The following operations and uses are permitted in the watercourses and wetlands areas of the Township as a matter of right, subject to the provisions of section one (1):

1. Conservation of soll, vegetation, water, fish and wildlife;

2. Outdoor recreation including play and sporting areas; filed trails for nature study, hiking, and horseback riding; swimming, skin diving, boatIng, trapping, hunting, and fishing where otherwise legally permitted and regulated;

3. Grazing, farming, gardening and harvesting of crops, and forestry and nursery practices where otherwise legally permitted and regulated;

4. Operation and maintenance of existing dams and other water control devices, and temporary alteration or diversion of water levels or circulation: 
for emergency malntenance or aquiculture purposes, if in compliance with state statutes.

B. The following operations and uses are permitted if done pursuant to terms and conditions of a permit approved by the Township Board. Where a final subdivision plat or final site development plan bas been approved by the Township Board, such approval, together with any additional terms and conditions attached thereto, shall constitute such a permit:

1. Docks, bulkheads, boat launching or landing sites;

2. Municipal or utility use such as water works pumping stations, parks, and recreation facilities, when involving any alteration of existing natural conditions of watercourses or wetland areas;

3. Private recreation facilities as permitted and regulated under section of the Township Zoning Ordinance, and when consistent with the intent and objectives of this Ordinance;

4. Dams and other water control devices, dredging or diversion of water levels or circulation, or changes in watercourses for the purposes of improving fish or wildife habitat, recreation facilities or drainage conditions, when consistent with the intent and objectives of this Ordinance and otherwise permitted under state statutes;

5. Utility trasmission lines;

6. Driveways and roads where alternative means of access are proven to be impractical.

SECTION 3. Scope of Permits. All uses and operations permitted or approved by such permits shall be conducted in such a manner as will cause the least possible damage and encroachment or interference with natural resources and natural processes within watercourses and wetland areas in the Township.

The Township Board shall upon the adoption of a resolution directing the issuance of a permit:

A. Impose such conditions on the manner and extent of the proposed operation, use or activity as are necessary to ensure that the intent of this Ordinance is carried out;

B. Fix a reasonable time within which any removal or deposition operations must be completed; 
C. Require the fillng with the Township of a cagh or surety performance bond, in such form and amount as determined necessary be the Commission to ensure compliance with the approved permit.

\section{SECTION 4. Permit Procedure.}

A. All applicants for a permit to do any of the acts permitted by this Article shall present six copies of the permit application together with other required information and materials to the Township Planning Commission. Thereafter, procedural matters shall be controlled by Article Four. (IV).

B. All applications and copies thereof must be accompanied by or include the following information and fee:

1. Name and address of applicant and of applicant's agent, if any and whether applicant is owner, lesee, license, etc. If applicant is not owner, the written consent of the owner, duly acknowledged, must be attached.

2. Amount and type of material proposed to be removed or deposited, or proposed type of use or activity.

3. Purpose of proposed removal or deposition operations, use or activity.

4. Survey and topographical map of the property upon which such operation or use is proposed, prepared in manner prescribed in subsection $C$.

5. Description of the proposed manner in which material will be removed or deposited, structure installed or use carried out.

6. Aflling fee of fifty dollars $(\$ 50.00)$.

$\because$ The permit application shall be accompanied by a survey and topographical map drawn to a scale of no smaller than one inch equals 30 feet, prepared and certified substantially correct by a registered land surveyor or engineer, and including the information listed below. Whenever the cost of the proposed operation does not exceed $\$ 100.00$, the plans and specifications need not be prepared by a licensed practitioner:

1. Name and address of owner of record of the affected property, and of the applicant if other than owner, location and dimensions of all boundary lines, names of the owners of record of adjoining properties and properties directly across any road, graphic scale, north arrow and date. 
2. Existing contour data for the entire property with a vertical interval of no more than ten feet, and contour data at an interval of no more than one foot for all areas to be disturbed by the proposed operation, extending for a distance of at least 50 feet beyond the 1 imits of sucb areas. Indicated elevation shall be based on an established datum which specify the relationship to sea level.

3. Specifications of the extent of all areas to be disturbed, the depth to which removal or deposition operations are proposed, and the angle of repose of all slopes of deposited materials and/ or sides of channels or excavations resulting from removal operations.

4. An area map at a scale of one incb equals 200 feet showing property 1 ines and proposed changes in the location and extent of existing watercourses and wetland areas.

SECTION 5. Exceptions for Small Wetland Areas. This Ordinance shall not apply to wetlands as defined and designated under Article three (III) which cover an area of less than one (1) acre.

SECTION 6. Inspections. The permit applicant or his agent proceeding with approved operations shall carry on his person or have readily avallable the approved permit and show same to any agency or agent of the Township whenever requested.

Operations conducted under such permits shall be open to Inspection at any time by any agency or agent of the Township or state.

SECTION 7. Invalidated Permits. Subject to the procedures in Article four (IV), any decision regarding a permit application under this ordinance shall be judicially reviewable. In the event that, based upon proceedings and decision of an appropriate court of the state, a taking is declared, the Township may, within the time specified by such court, elect to:

A. Institute condemnation proceedings to acquire the applicants' land in fee by purchase at fair market value; or

B. Approve a permit application with lesser restrictions or conditions.

SECTION 8. Penalties and Enforcement. 
A. Any person found guilty of violating any of the provisions of this ordinance shall be punished by a fine not to exceed $\$ 100.00$ or imprisonment not to exceed 90 days, or by both such fine and imprisonment in the discretion of the court. The Commission, in addition to other remedies, may institute any appropriate action or proceeding to prevent, abate or restrain the violation. Each day's continuance of a violation shall be deemed a separate and distinct offence.

B. The grant or denial of a permit shall not have any effect on any remedy of any person at law or in equity; Provided, that where it is shown that there is a wrongful failure to comply with this ordinance, there shall be a rebuttable presumption that the obstruction was the proximate cause of the flooding of the land of any person bringing suit. 
An Ordinance establishing a setback line for those lots or tracts lying wholly or partially within the following described area, to it: (omitted legal desciption)

providing for a decreased minimum setback through transfer of rights from a contiguous tract to the transferee tract; providing a penalty clause; providing a severability clause; and providing an effective date.

WHEREAS, the City Council has heretofore recognized the need to make a study of the Turtle Creek Environmental Corridor in order to preserve the open space of those lands adjoining streets from Turtle Creek Parway, Lee Park and Reverchon Park from Wycliff Avenue to Maple Avenue in the City of Dallas; and

WHEREAS, on February 25. 1971, the City Plan Commission of the City of Dallas adopted the interim comprehensive plan for the Oak Lawn Community and this study recommended the protection and preservation of the Turtle Creek Parway Corridor; and

WHEREAS, the :City Plan Commission held a public hearing on October 10,1974, with reference to said Turtle Creek Environmental Corridor study followed by a hearing before the Parl and Recreation Board of the City of Dallas on October 17, 1974, and both the City Plan Commission and the Park and Recreation Board of the City of Dallas recommended the adoption of the Turtle Creek Environmental Corridor Plan as described in said study thereof; and

mHEREAS, the City Council of the Dallas at a public hearing held on November 3,1974 , after considering the recommendations of both the City plan Commission and the Park and Recreation Board of the City of Dallas, directed that an ordinance be prepared containing the guldelines and standards for the Turtle Creek Environmental Corridor as hereinafter set forth; Now, Therefore,

BE IT ORDAINED BY THE CITY COUNCIL OF THE CITY OF DALLAS:

SECTION 1. There is hereby created an area to be known as the "Turtle Creek Environmental Corridor, hereinafter referred to as "the Corridor". Such Corridor shall be composed of those lots or tracts which are partially or wholly contained within the following area:

\section{(legal description omitted)}

SECTION 2. The following guidelines and standards shall hereafter govern development within the Corridor: 
A. No off-street vehicular parking surface shall be constructed closer than 50 feet from the right-of-way line of Turtle Creek Boulevard, Turtle Creek Drive and Cedar Springs Road (when Cedar Springs Road is positioned in a nor theast-southwest direction), or closer than 50 feet from the centerline of Turtle Creek. No building permit for any proposed subsurface parking facility shall be issued by the Building Inspector unless a surface landscape plan for such lot or tract has been approved by the Park and Recreation Board of the City.

B. Except as provided in subsections (c) and (d) of this Section, and section 3 of this Ordinance, no structure shall be constructed closer to the right-of-way lines of Turtle Creek Boulevard, Turtle Creek Drive, and Cedar Springs Road (when Cedar Springs Road is positioned in a northeast-southwest direction), than as specified below:

$\begin{array}{crc}\text { Stories } & \begin{array}{r}\text { Height } \\ \text { (Feet) }\end{array} & \begin{array}{c}\text { Setback } \\ \text { (Feet) }\end{array} \\ 1 & 12 & 25 \\ 2 & 24 & 36 \\ 3 & 36 & 44 \\ 4 & 48 & 50 \\ 5 & 60 & 55 \\ 6 & 72 & 59 \\ 7 & 84 & 62 \\ 8 & 96 & 65 \\ 9 & 108 & 67 \\ 10 & 120 & 68 \\ 11 & 132 & 69 \\ 12 & 144 & 70 \\ 13 & 156 & 71 \\ 14 & 168 & 72 \\ 15 & 180 & 72 \\ 16 & 192 & 73 \\ 17 & 204 & 73 \\ 18 & 216 & 74 \\ 19 & 228 & 74 \\ 20 & 240 & 75\end{array}$

For those properties lying between the M K \& T Railroad rightof-way and Turtle Creek, such setback shall be measured from the centerline of Turtle Creek.

C. At the intersections of Turtle Creek Boulevard with Blackburn Street, with Lemmon Avenue, with Hall Street, and with Cedar Springs Road, and the intersection of Turtle Creek Drive with Gillespie street, no structure shall be constructed closer to such intersection than an imaginary line formed between points on each curb 1 ine 100 feet from such intersection. 
D. On those lots or tracts which face Lee Park or Reverchon Park across a public right-of-way, no structure or surface parking shall be constructed closer to the front property ine than 25 feet.

SECTION 3. The minimum setback for any building or other structure may be decreased by transfer to such lot of an allowable setback which is unused upon a contiguous lot which is located within the Corridor. Such transferred rights may be used at a ratio of 2 feet acquired for every 1 foot used. No transfer of additional setback shall be effective unless an instrument, in a form approved by the city Attorney, has been executed by the parties concerned and recorded in the Deed Records of Dallas County, Texas, serving as a notice of the restrictions under this ordinance applying to both the contiguous lot and the transferred lot. Such document shall specify (1) the amount of setback to be transferred, the decreased minimum setback permitted on the transferee lot by virtue of transfer, and the increased minimum setback on the contiguous lot; (2) the duration of the transfer, which shall be specified to be less than the actual Ifetime of any building on the transferee lot whose construction is made possible, in whole or in part, by the transfer; (3) the effect of any subsequent changes in the setback requirements under this ordinance for both lots; and (4) the effect of any subsequent change in the size of either lot, whether by virtue of conveyance, condemnation or otherwise, upon the setback for both lots. In no case shall the setback of the transferee lot be less than that minimum specified below:

Stories

Height

(Feet)

1

2

3

4

5

6

7

8

11

12

13

14

15

16

17

18

19

20
12

24

36

48

60

72

84

96

108

120

132

144

156

168

180

192

204

216

228

240
Minimum

Setback

(Feet)

25

27

32

35

38

41

44

47

50

53

56

58

60

62

64

66

68

70

75 
SECTION 4. Any property owner within the corridor may on his own initiative, offer to the city subject to Park and Recreation Board aproval a dedication in tee aimple or for park purposes any area of land fronting on any public street in the corridor as permanent open space. Upon dedication of such property, the Tax Assessor shall reassess the remaining area to reflect such dedication prior to the next Assessment Ordinance, and the City shall maintain such property so dedicated within normal landscape standards. The Owner may, in lieu of such dedication, grant to the city a landscape easement on any area of land fronting any public street in the corridor. The City shall, upon approval of a landscape easement by the Park and Recreation Board, to be carried out by the property owner, either maintain the same or arrange for its maintainance, and the Tax Assessor shall make such tax reassessments as the facts justify. Any property dedicated or granted for a landscape easement shall be considered in computing floor-area ratio, coverage and density.

SECTION 5. A person who violates a provision of this ordinance is guilty of a separate offense for each day or portion of a day during which the violation is committed, continued, or permitted, and each offense is punishable by a fine not to exceed $\$ 200$. 
WILDLIFE REGULATIONS: TOWN OF JACRSON DEVELOPMENT CODE (JACKSON, WYOMING)

\section{CAAPTER 3 - GENERAL REGULATIONS}

Section 3-4 Design Standards and Development Standards

3-4-8 Natural Resources

A. Natural resources, especially wildlife areas and mineral resources, shall be protected. In the event that development is proposed in an area of known mineral deposits, the development applicant shall provide an estimate of the economic value by a registered engineer prior to approval of developement. The Town Council will make an evaluation of the value of both the resource and the cost of extraction prior development of the property. The Town Council may delay development approval until extraction has been accomplished or protection provided within the design of the development.

Development in areas designated as critical winter habtats shall not be allowed. Development which presents a barrier to wildlife migration routes or breeding areas as designated by Game and Fish shall be avoided as much as possible. If development occurs in such areas, it shall be clustered on portions of the site where the conflict will be minimized. Recommendations from the Department of Game and Fish shall be sought and incorporated into the development plan.

\section{3-4-14 Road Building Construction slash}

To avaid insects, diseases and wildlife hazards all cut combustible materials, vegetative residues, including fallen or cut trees or shrubs, pulled stumps or other such flammable road or building-clearing debris shall be disposed of from the subdivision roadside strips and lots by either chipping or removal. Compacting of slash and debris into road filled areas shall not be permitted.

Section 3-6 standards for Required Submittals, Reports, Studies, and Special Plans

\section{3-6-2 Impact statement}

This document has an indeterminant content because it is the nucleus of all written documentation required or provided by the applicant. Generally it shall contain:

project description 
Sumary of submittal materials

Statement of specific impacts such as water use, sewerage discharges, wildlife, traffic, pollution, environment, views, etc.

Site data-

Total area of project

Total area cleared

Total impervious area

Total open space and public sites

Total cuts and fills

Development data-

Number of lots

Description of buildings or housing units

Building areas, numbers of housing units by types

Parking spaces required and provided

3-6-3 B. Preliminary Plan

Engineering information submitted on preliminary plans is not intended to be detailed design. It should basically be a graphic plan which shows intent and answers basic engineering questions. A preliminary plan constitutes the major step in the review process. The submittals shall be detailed enough to answer the question, "Should this use, designed in this manner, be constructed on this site?"

Clear, crisp copies of map(s) of the proposed development. The map(s) shall be at a scale of not less than $1^{\prime \prime}=60^{\prime}\left(1^{\circ}=100^{\prime}\right.$ if lots are 2 acres or more each), and an accurate outer boundary survey with dimensions certified by a registered land surveyor licensed to work in the state of Wyoming. The drawings shall be on one or more sheets with outer dimensions of $24^{\circ} \times 36^{\circ}$.

Information to be shown:

7. Designation of wildife areas and migration routes 8. Identification of hazard areas and wildlife areas

Section 3-10 wildife Protection

\section{3-10-1 Purpose and scope}

This regulation applies to all identified wildlife reserves, riparian areas, and critical winter habitat. This includes waterways and surrounding water bodies. The intent of this regulation is to:

A. Guide development and land use near and in these areas.

B. Restrict development where adverse impacts are determined to exist by proposed development. 
c. Provide for possible cohabitation of people and wildlife on certain lands where possible.

D. Maintain current conditions for wildlife as minimum levels of response and to their needs work toward improving these conditions.

\section{3-10-3 Validity}

A wildlife area, once identified, shall remain intact and unchanged or suffer changing conditions over time. Wildlife areas shall be identified as public lands and dedicated in the platting process. If platting is not required, an easement for public access must be established and recorded.

Changes in wildife areas can only be accomplished through a public hearing process.

\section{3-10-4 General Requirements}

A. Boundaries of wildlife habitats and migration routes shall be identified by the Division of Wildlife, State Game and Fish, and the U.S. Forest Service. These shall be accurately identified on subject properties and designated as public land.

B. These same agencies shall establish methods of protection, special structures for access and control, and vegetation that will be required to establ ish a permanent working habitat. These comments shall be addressed by the applicant and incorporated into the project.

C. All development shall enhance the wildife areas.

D. All requirements of this Code shall be applied to development in and around wildlife areas. The Commission may modify certain requirements if it is deemed in the best interests of a specific situation.

E. No creek channel alterations such as filling, relocation or development in the channel that would encroach on the creek shall be permitted, unless the change would improve habitat for cutthroat trout and has been approved by the Wyoming Department of Game and Fish.

F. Creek crossing shall be minimized and bridges used instead of culverts, unless otherwise approved by the Wyoming Department of Game and Fish. 
G. No buildings shall be allowed within 50 feet of the riparian zone of any creek.

B. In areas with no apparent riparian habitat, the size of this habitat shall be determined from adjacent areas that do have riparian habitat.

I. Meander fingeres less than 150 feet wide shall not be disturbed as these are likely to be covered by riparian vegetation.

J. No development of brush covered slopes should be allowed in mule deer winter range areas.

R. An open corridor for elk movement to the state feed ground must be maintained undeveloped.

L. Areas within 300 yards of bald eagle or osprey nests or other important habitat for these species as determined by the Wyoming Department of Game and Fish shall be left undisturbed.

M. Fences shall conform to the Wyoming Department of Game and Fish design criteria.

N. Access roads shall run parallel to creeks and springs whenever possible to maintain movement corridors for big game animals.

\section{CHAPTER 4 SUBDIVISION OF LAND AND PROCEEDURES}

Section 4-5 Preliminary Plan Requirements

$4-5-2$

J. The proposed development will not have any significant undue adverse impact on Town's scenic or wildlife resources. 
TETON COONTY WILDLIFE REGULATIONS

(TETON COUNTY, WYOMING)

\section{CHAPTER 3: ENVIRONMENTAL PROTECTION DISTRICTS}

Section 11 Regulations for Watercourse Protection District

B. No structure of clearing of vegetation shall be permitted that would disrupt a wildlife habitat, wildlife migration route, or fishery except where necessary for a road or a utility crossing. Where a structure or clearing is essential, it shall be $1 \mathrm{im}$ ited to the minimum area that is feasible. In addition, the setback requirements of Chapter 4, Section 19, shall apply.

C. Dredging and stream channel alterations shall be prohibited except where part of a flood protection project or channel stabilization project authorized by the County, or where authorized by a permit issued by the U.S. Corps of Engineers.

D. Where grading is essential to a development project, land alteration including any road that must parallel a watercourse to provide access to properties, shall be located as far from the watercourse as is feasible.

E. Permanent fills with the exception of dikes shall not be located so that stormwater runoff will carry sediment into any river, stream, or creek, shall not be located closer than 50 feet to a defined bank of a river, stream, or creek, and shall not be constructed in a manner that will allow sediment to run off onto adjoining property.

F. Damage to existing vegetation within 50 feet of any river, stream, or creek shall be minimized except where necessary for road or utility crossings, and for drainage structures required by these regulations.

\section{CHAPTER 6: DEVELOPMENT PERMITS}

Section 8 Required Considerations

I. Potential effects on wildlife habitats, wildlife migration routes, and fisheries.

Section 9 Required Findings

Before recommending or granting a development permit, the Planning Commission and the Board of County Commissioners shall make the following findings: 
R. The proposed use will not significantly adversely affect wildife with respect to the site's vegetation or water resources in supplying food, water, cover, nesting, or other needs of wildlife.

L. No element of the proposed use, including buildings, drives, pedestrian walkways, and recreation areas, will intrude on watercourses, bogs, lakes, or other areas that are critical wildife habitats.

M. No element of the proposed use will intrude on or present a barrier to wildlife migration, movement, routes, calving, fawning, or nesting areas.

N. Development will be limited to those portions of the site having the least wildlife habitat value.

0. The physical configuration of the development will be such that it does not encircle any areas of high wildife habitat value.

P. Developed and open space areas are designed to retain and enhance existing and potential wildlife habitats.

Q. The proposed use will not interfere with existing agricultural water rights, and provision has been made to ensure access to agricultural water supplies for maintenance. 


\section{CLUSTERED RESIDENTIAL DEVELOPMENT AND PLANNED UNIT DEVELOPMENT (TETON COUNTY, WOMING)}

\section{Section 1 Purposes}

This chapter is intended to encourage clustering of residential development to achieve preservation of open space and scenic areas and consequently the protection of wildlife migration routes and habitats and encouragement of ranching activities. It is also the intent of this chapter to encourage compact rather than randomly scattered development and to encourage concentration of development on the portion of the site most suitable for development and where development will be least visually prominent.

Section 2 where Permitted

Subject to the issuance of a development premit, in accord with the provisions of Chapter 6, planned unit development or clustered residential development may be permitted in any RA(Residential/Agricultural) District.

Section 3 Maximum Number of Units

The maximum number of units that may be contained in a clustered residential development or in a planned unit development shall be determined as follows:

A. A clustered residential development may contain as many units as would be permitted on the entire site by the density limitations prescribed for the land use district or districts within which it is located. Where open space is permanently preserved, a planned unit development may contain as many additional units as are authorized by the bonus provisions of section 6 of this chapter.

B. A planned unit development may contain as many units as would be permitted on the entire site by the density limitations prescribed for the land use district or districts within which it is located. Where open space is permanently preserved, a planned unit development may contain as many additional units as are authorized by the bonus provisions of section 7 of this chapter.

Section 4 Sites in More than One Land Use District

Where the site of a proposed clustered residential development is located in more than one land use district, the following regulations shall apply: 
A. The maximum number of units on the site shall be the sum of the number of units that are permitted by the density limitations prescribed for each separate land use district within which the respective portions of the site are located, without regard to the authorized density bonus.

B. If a portion of the site is located in a RA-6/3 (Variable) Residential/Agricultural District, and all of the units are to be located on a portion of the site within which a density of 1 unit per 3 acres would be permitted by the land use district regulations, a credit of 1 unit per 3 acres may be claimed for the portion of the site in the $R A-6 / 3$ (Variable) District in determining the maximum number of units that may be permitted on the entire site.

C. Provided that sufficient land area is available to meet the standards prescribed in Section 8 of this chapter, the development shall be located on the portion of the site on which the greater density would be permitted by the land use district regulations. If sufficient land area is not available to locate all of the development there, then as much of the development as the Board of County Commissioners may determine, at its discretion, to be sufficient shall be located on that portion of the site.

\section{Section 5 wastewater Treatment}

Connection with a municpal wastewater treatment system, where available, or a community wastewater treatment system shall be required to serve a clustered residential development or a planned unit development, provided that for small clustered developments or for portions of a planned unit development containing small concentrations of development on sites free of ground water problems, individual of shared septic tank systems meeting all required standards of installation shall be permitted if authorized by the County Sanitarian or the Wyoming Department of Environmental Quality.

Section 6 Density Bonus for Clustered Residential Development

Except where the site is located in a 25-50 Year Flood Protection District, a desity bonus not exceeding a total of 50 percent mor units than otherwise would be permitted by the land use district regulations may be authorized in a clustered residential development subject to the following conditions: 
A. To qualify for a density bonus, the site shall be a minimum of 20 acres in area.

B. Not less than 58 percent of the site shall be permanently preserved as open space.

C. The density on the developed portions of the site shall not exceed four units per acre.

Section 7 Density Bonus for Planned Unit Development

Except where the site is located in a 25-50 Year Flood Protection District, a density bonus not exceeding 100 percent more units than otherwise would be permitted by the land use district regulations may be authorized in a planned unit development subject to the following conditions:

A. To qualify for a density bonus, the site shall be a minimum of 200 acres in area.

B. To qualify for a density bonus, not less than 50 percent of the site shall be permanently preserved as open space.

C. The density on the developed portion of the site shall not exceed 8 units per acre.

Section 8 Open Space Requirements

In order to qualify for a density bonus as prescribed in sections 6 and 7 of this chapter, the permanently preserved open space shall conform with the following requirements :

A. Portions of the site devoted to required setbacks, roads, drives, parking areas, gardens, cut or fill slopes, sewage treatment lagoons, or other disturbed areas, except for ground surfaces that are disturbed to accommodate agricultural activities or for a flood control project, shall not be counted as credit for a density bonus.

B. The portion of the site preserved as open space shall remain in agricultural use or in its undisturbed natural state, shall remain a wildlife habitat or migration route, or specifically shall be found by the Board of County Commissioners to yield some other benefit to the public by reason of its preservation.

C. The portion of the site preserved as open space and for which credit for a density bonus is given shall be specifically described by an acceptable 
survey, and shall be made subject to a scenic easement which is dedicated in perpetuity to the scenic Preserve Trust of Teton County or to a tax-exempt non-profit foundation, or shall be dedicated in fee to the scenic Preserve Trust or to a tax-exempt, non-profit foundation.

D. In lieu of provisions for dedication prescribed in Subsection $c$, subject to approval by the Board of County Commissioners, an undivided interest in the open space area for which credit for a density bonus is given may be conveyed to an association of property owners within the clustered residential development or the planned unit development, subject to deed restrictions limiting the uses of the open space area to those prescribed in subsection b.

\section{Section 9 Development Standards}

Clustered developments and planned unit developments shall conform with the performance standards of Chapter 4, and with the following standards:

A. Development shall be concentrated in areas of heaviest tree cover on sites where tree cover exists, provided that such siting does not conflict with any of the wildlife and habitat protection standards prescribed in Chapter 6, Sections 8-9, and except where it would be necessary to construct an access road across slopes greater than 36 percent or to construct an access road within the site exceeding 1,800 feet in length to conform with the standard.

B. Any building, structure, drive, or parking area shall be set back from the land to be preserved in open space for a distance not less than 50 feet.

C. Setbacks for all buildings and other impervious surfaces shall be the same as those prescribed for RA districts in Chapter 4, Section 19. When the site of a development is located in more than one land use district, the setback requirements for that district where the development is actually sited shall govern. When the site of the development itself, excluding the area to be preserved in open space, is located in more than one land use district, the more stringent setback requirements shall govern.

D. The distance between separate buildings in a development shall conform with the following regulations: 
1. A distance of 30 feet shall be provided between a single family residence and any other residential building of any type.

2. For townhouses, condominiums, apartments, and detached accessory buildings, including those accessory to single family residences, there shall be a minimum distance between buildings of ten feet for buildings one story or 15 feet in height, 15 feet for buildings two stories or 25 feet in height, and 28 feet for buildings three stories or 35 feet in height. When buildings have varying heights, the distance requirement for the tallest building shall govern.

E. The length of any single building shall not exceed 150 feet. This measurement shall be the greatest horizontal dimension of any exterior wall of the building. For buildings with wall indentations, the measurement shall be between the two farthest points along the same horizontal wall plane.

F. The maximum height of buildings and structures shall be the same as those prescribed for RA districts in Chapter 4, Section 21 .

G. No more than one-half of the total length of the periphery of the open space to be preserved shall abut any portion of the land on which the development itself is located.

H. The layout of a development shall be designed to minimize the length of internal roads and driveways and to minimize their intrusion on pedestrian areas and recreational areas. 
TRANSFER OF DWELLING UNITS ORDINANCE (SOUTHEAST, N.Y)

ARTICLE 17A Transfer of dwelling units

17A.I General: In accordance with the procedures and standards hereinafter specified, the Southeast Planning Board may grant special exceptions to permit transfer of eligible Planned Subdivision Plat lots under Article 16 and dwellings containing two (2) or more dwelling units under Article 17 from one tract of land to another. All provisions of this Article are in addition to other provisions applicable under Article 16 and 17 except as such provisions are modified herein.

17A.2 Purpose: It is found and determined that conditions affecting development of land in Residence Districts in the Town of Southeast vary significantly from one tract to another with regard to topographic conditions, resources for water supply and sewer disposal, current availability of community facilities and the condition of highway access. Within the established pattern of Residence Districts there are tracts of land having conditions more favorable for early development while there are other tracts having conditions less favorable or on which residential building construction would be best not occur. Based on individual cases and the condition of particular tracts of land, it will be beneficial for the orderly growth and development of the Town of Southeast to permit transfer of eligible residential building lots and/or dwelling units from one tract to another for the following purposes:

17A.2.1 To reserve permanently tracts of land having assets for park, recreation, conservation and other open space purpurposes:

17A.2.2 To avoid premature development or tracts in remote locations, distant from community facilities or served by rural roads:

17A.2.3 To encourage an orderly pattern and growth of residential neighborhoods in a manner that makes use of suitable streets and highways and that provides for construction and extension of central water supply and sewage disposal systems: and /or

17A.2.4. To further the timely and economical provisions of community facilities.

17A.3 Application. Application for a special exception for transfer of lots and/or dwelling units shall be submitted in writing to the Southeast Planning Board, simultaneously with an application for a special exception under Article 16 or 17 for the tract to which lots and/or units are to be transferred; the application shall be accompanied by the fol- 
lowing in additon to the requirements of Paragraph 16.3 and 17.2 as applicable:

17A.3.1. Statement: A written statement describing the number and type of lots or units to be transferred, the purposes which will be accomplished by the transfer and the proposed use and ownership of the tract from which transfer is to be made.

17A.3.2. Preliminary Plat: A preliminary subdivision plat showing a layout of the tract from which transfer is to be made and conforming to the regular provisions of this Ordinance and the Land Subdivision Regulations of the Town of Southeast.

17A.3.3. Other: The Southeast Planning Board may request the submission of additonal information that it deems necessary in order to decide on the application.

17A.3.4. Application Fee: An application fee of $\$ 100.00$ or $\$ 10.00$ for each acre of land in the tract from which transfer is to be made, whichever is greater.

17A.4. Review and Referral: Upon receipt of a special exception application, the Southeast Planning Board shall review the submission for completeness, meet with the applicant and conduct a study of the applicant and shall transmit to the Town Board a copy of the application together with a written evaluation thereof.

17A.5. Town Board: The Town Board may recommend to the Planning Board approval of the application, approval subject to modifications of disapproval. The recommendations of the Town Board shall take into account the purposes set forth in Paragraph 17A.2 and the effect of the transfer upon the comprehensive plan for zoning for the Town of Southeast including but not limited to the development and preserva$t$ ion of sound neighborhoods and the impact upon municipal services and facilities. No recommendation of approval or approval subject to modifications shall be made by the Town Board until a public hearing has been held by the Town Board. The hearing shall be advertised twice in a newspaper of general circulation in the Town, and the firest advertisement shall be published at least seven (7) days before such hearing.

17A.6 Planning Board Procedure: No application shall be approved by the Southeast Planning Board or approved subject to modifications until a public hearing on the application has been held by such Board. The hearing shall be advertised twice in a newspaper of general circulation in the Town, and the first advertisement shall be published at least seven (7) days before such hearing. The Southeast Planning Board shall not decide on the application until 
after a recommendation has been made by the Town Board, as provided in Paragraph 17A.5. The Southeast Planning Board shall decide on any application simultaneously with a decision on an application under Article 16 or 17 as applicable. The Southeast Planning Board may approve the application, granting the special exception, if the Board finds that the standards specified in Paragraph $17 \mathrm{~A} .7$ will be. met and that the transfer will not be detrimental to the public health and safety and property values, and if the Town Board has not recommended disapproval of the application.

17A.7 Standards: Special exceptions for transfer of lots and/or dwelling units under this Article shall conform to the following standards:

17A.7.1 District: Lots and/or dwelling units shall be transferred as follows:

a. between tracts in Residence Districts;

b. between tracts in the same Residence District or to a Residence District having lesser lot areas requirements; and

c. between tracts in 1 the same School District.

17A.7.2 Number Transferred: The number of lots and/or dwelling units transferred shall not exceed the following:

a. for lots, the number shown on the preliminary subdivision plat submitted under Paragraph 17A.3.2 which the Southeast Planning Board determines can reasonably be created in conformity to the regular provision of this Ordinance and the Land Subdivision Regulations of the Town of Southeast; and

b. for dwelling units, such number of one-bedroom units or two-bedroom lunits, or mixture thereof, having a total number of bedrooms not exceeding four (4) times the number of lots shown on the preliminary subdivision plan submitted under Paragraph 17A.3.2 which the Southeast Planning Board determines can reasonably be created in conformity to the regular provisions of this Ordinance and the Land Subdiyision Regulations of the Town of Southeast but excluding from the computation such number of lots as may be transferred under Paragraph 17A.7.2(a).

17A.7.3 Receiving Tract: With transfer of lots and/or dwelling units, development on the tract to which transfer is made shall conform to the following:

a. Lots for single detached dwellings for one (1) family shall conform to the lot area, shape and front- 
age requirements of Paragraph 16.8 .3 for the District in which the tract is located.

b. Tracts to which dwellings contained two (2) or more dwelling units are transferred shall contain the following minimum area for each dwelling unit, excluding any right-of-way for existing or proposed streets and any lots for single detached dwellings:

$\begin{array}{ccr}\text { District } & \begin{array}{c}\text { Lot Area Per One } \\ \text { Bedroom Dwelling Unit } \\ \text { (Square Feet) }\end{array} & \begin{array}{r}\text { Lot Area Pe } \\ \text { Bedroom Dwe } \\ \text { (Square }\end{array} \\ \text { R-1 } & 10,000 & 20,000 \\ & 5,000 & 10,000 \\ 3,500 & 5,000 \\ 3,500 & 5,000\end{array}$

c. Lots and dwelling units shall be provided with water supply and sewerage facilities as specified in Paragraph $17 \cdot 6.8$.

d. The tract shall have access as specified in Paragraph 17.6 .4 .

e. The tract shall be capable of accommodating all of the lots and/or dwelling units permitted under Article 16 or 17 as applicable plus the lots and/or dwelling units transferrable, or such lesser number that the southeast Planning Board may determine, in such a manner as to conform to the appropriate and orderly development of the neighborhood, to not hinder the appropriate use of adjacent property and to preserve the appearance and character of the neighbor hood.

17A.7.4 Sending Tract: The tract from which lots an/or dwelling units are transferred shall be suitable for and permanently reserved for park, recreation, conservation and other open space purposes or for municipal or education facilities and shall have access, shape, dimension, character location and topography suitable for the purpose intended as approved by the southeast planning Board. The use of any other purpose, including lots for dwelling construction, shall be excluded by covenant in deed, in form approved by the Town Board. The tract may vbe conveyed to the Town if accepted by the Town Board or shall by other means, approved by the Southeast Planning Board, be owned and maintained for the approved purpose.

17A.7.5 Open Space: When lots for single detached dwellings are transferred, an area or areas of open space land shall be reserved as specified in Paragraph 16.8.6, which area may be located on the tract to which or from which transfer is 
made or any combination thereof.

17A.7.6 Conformity to Purpose: The transfer of lots and/or dwelling units shall result in accomplishment of one or inire of the purposes set forth in Paragraph $17 \mathrm{~A} .2$. 


\section{Bibliegraphy}

1. Barske, Phillip. The growing importance of privately owned woodlands to wildlife habitat. In: Transactions of The Northeast Fish and Wildlife conference_of 1972 , Ellenville, New York, 1973, 213pp.

2. Brokaw, H.P.(Ed). Wildlife and America, Council on Environmental Quality, U.S. Government Printing Office, Washington, 1978, p.5.

3. Commitee on Agriculatural Land Use and Wildife Resources, Land Use and Wildlife Resources, National Academy of Sciences, Washington, 1970, 262pp.

4. Cowardin, Lewis M., Virginia Carter, Francis C. Golet, and Edward T. La Roe. Classification of Wetlands and Deepwater Habitats of the United States, office of Biological Services, Fish and Wildlife Service, U.S. Government Printing office, Washington, 1979, p.l1.

5. CPAD Urban Field Center, Cooperative Extension Service, and the University of Rhode Island, Rreserving Open Space: Approaches for Rhode Island Communities, $1978,42 \mathrm{pp}$.

6. Dasmond, Raymond F. Wildlife Biology, 2nd ed., John Wiley and Sons, New York, 1981 , p.184.

7. DeChiara, Joseph, and Lee E. Koppelman. Time-saver Standards for Site Planning, McGraw-Hill, New York, $1984,849 \mathrm{pp}$.

8. Department of the Environment, Sinews for Survival, London:HMSO, British governments submission to the: United Nations Conference on the Human Envirenment, Stockholm, 1972

9. Ehrilich, Paul, and Anne Ehrlich. Extinction: The causes and Consequences of the Disappearance of species, Random House, New York, 1981, 305pp.

10. Fish and Wildlife Conservation Act of 1980, Public Law 96-366-Sept.29,1980, 94 STAT.1323 16USC 2902

11. Frankel, O.H., and M.E. Soule. Conservation and Evolution, Cambriage University Press, Cambridge, 1981, p.36. 
12. Franklin, I.A. Evolutionary change in small populations, In: Conservation Biology: An Evolutionary-Ecelogical Perspective, Eds. M.E. Soule and B.A. Wilcox, Sinauer Associates, Sunderland,Mass., 1980, pp.135-150.

13. Grahm, Bob v. Estuary Properties, Inc., 399 So.2d. 1374

15. Gray, G.G., J.S. Larson, and D.A. Braunhardt. Urban conservation leadership and the wildlife resource, Urban Ecology, 1979, 4(1) pp.1-9.

16. Hallock, Dave. Boulder County makes room for wildife, Planning, $1984,50(9) \mathrm{pp} .12-14$.

17. Harestad, A.S., and F.L. Bunnel. Home range and body weight - a re-evaluation, Ecology, 1979, (69) pp.389-402

18. Harris, Larry D. The Fragmented Forest: Island Biogeography and the Preservation of Biotic Diversity, University of Chicago Press, Chicago, 1984, 21lpp.

19. Horizon Adirondack Corp. v. State of N.Y. (388 NYS2d. 235); Albano v. Washington (194 N.J., Sup. 265); Steel Hill Dev. Inc. v. Town of Sanbornton, et al. (469 F2d. 956).

20. Humke, John E., Barry S. Tindall, Robert E. Jenkins, Hardy L. Wieting Jr., and Margaret S. Lukowski. The Preservation of Natural Diversity A survey and Recommendations, The Nature Conservancy, 2nd ed., 1975, 212pp.

21. Iltis, H.H., P. Andrews, and 0. Loucks. Criteria for an optimum human environment, Bulletin of Atomic Scientists, 1970, 26(1) pp.2-6.

21. Leedy, Daniel L., Robert M. Maestro, and Thomas M. Franklin. Planning for Wildlife in Cities and Suburbs, Urban Wildlife Research Center, Inc., Ellicott City, MD, 1978, 64pp.

22. Leopold, Aldo. Sand County Almanac, oxford University Press, New York, 1949, p.204.

23. Moviematic Ind. v. Bd. of County Commissioners, Fla., App., 349 So.2d 667 , p.667. 
24. Orleans Builders and Developers v. Byrne, 186 N.J.Super.432, p.433

25. Parson, Ruben L. Conserying American Resources, 3 rd ed. . Prentice-Hall Inc., Englewood Cliffs, 1972 , 608pp.

26. Phillips, Patrick. Nantucket,s land bank: a new direction in land conservation, Urban land, 1985, 44 (12) pp. 34-35.

27. Preston, F.W. The canonical distribution of commoness and rarity, Ecology, 1962, Part 1 (43) pp.185-215, Part 2 (43) pp. 410-432.

28. Regenstein, Lewis. The Politics of Extinction: the Shocking story of the World's Endangered Wildlife, MacMillan Publishing Co. Inc., 1975, 280pp.

29. Rhode Island statewide Planning Program, Methods of Eliminating conflicts, Technical paper Number 82 , Appendix, 1979, p.A-17.

30. Sarasota County v. Barg, Fla., 302 So.2d. 737, p.737.

31. Sargent, F.O., and J.H. Brande. Classifying and evaluating unique natural areas for planning purposes, Journal of Soil and Water Conservation, 1976, 31(3) pp.113-116.

32. Susskind, Lawrence, and Scott McCreary. Techniques for resolving coastal resource management disputes through negotiation, Journal of the American Planning Asseciation, $1985,51(3) \mathrm{pp} .365-374$.

33. Thomas, Jack Ward(Ed). Wildlife Habitats in Managed Forests: The Blue Mountains of oregon and Washington, Agriculatural Handbook No. 553, U.S. Department of Agriculture, Forest Service, Wildlife Management Institute, Washington, 1979, 51lpp.

34. Tiner, Ralph W. Jr. Wetlands of the United States: Current status and Recent Trends, U.S. Fish and Wildlife Service, U.S. Government Printing office, Washington, 1984,59pp.

35. Town of Jackson, Town of Jackson Develogment Cede, Jackson, Wyoming, 1983

36. Udall, stewart L. The Quiet Crisis, Holt, Rinehart, and Winston, New York, 1963, 209pp. 
37. U.S. Department of Interior, Fish and Wildlife Service, Selected List of Federal Laws and Treaties Belating to sport Fish and Wildlife, U.S. Government Printing office, Washington, 1979, pp.1-23.

38. Walker, Donald V.H., and Martin E. Zeller. Promoting public/private initiatives for preservation: Colorado open lands, Urban Land, 1985, 44 (11) pp.12-14.

39. Zube, Ervin H., Robert O. Brush, and Julius G. Fabos. Landscape Assessment: Values, Perceptions, and Resources, Dowden, Hutchinson, and Ross Inc., Stroudsberg, $1975,367 \mathrm{pp}$. 